Cristiane Maria Galvão Barbosa

\title{
Avaliação cardiovascular e respiratória em um grupo de trabalhadores cortadores de cana-de-açúcar queimada no estado de São Paulo
}

\author{
Tese apresentada a Faculdade de Medicina \\ da Universidade de São Paulo para obtenção \\ do título de Doutor em Ciências \\ Programa de: Pneumologia \\ Orientador: Dr. Ubiratan da Paula Santos
}

Versão corrigida, a original se encontra disponível na FMUSP 


\section{NORMATIZAÇÃO}

Esta tese segue as normas seguintes, em vigor no momento da publicação:

Referências: International Commitee of Medical Journals editors (Vancouver), através do gerenciador bibliográfico Endnote ${ }^{\odot} \mathrm{XI}\left(\right.$ Thompson inc $^{\odot}$ )

Universidade de São Paulo. Faculdade de Medicina. Serviço de Biblioteca e Documentação. Guia de apresentação de dissertações, teses e monografias. Elaborado por Annelise Carneiro da Cunha, Maria Julia de A. L. Freddi F. Crestina, Marinalva de Souza Aragão, Suely Campos Cardoso, Valéria Vilhena. 2ª Edição São Paulo: Serviço de Biblioteca e Documentação; 2005.

Abreviaturas dos títulos dos periódicos de acordo com List of Journals Indexed in Index Medicus 
Dados Internacionais de Catalogação na Publicação (CIP)

Preparada pela Biblioteca da

Faculdade de Medicina da Universidade de São Paulo

Creprodução autorizada pelo autor

Barbosa, Cristiane Maria Galvão

Avaliação cardiovascular e respiratória em um grupo de trabalhadores cortadores de cana-de-açúcar queimada no estado de São Paulo / Cristiane Maria Galvão Barbosa. -- São Paulo, 2010.

Tese(doutorado)--Faculdade de Medicina da Universidade de São Paulo. Programa de Pneumologia.

Orientador: Ubiratan de Paula Santos.

Descritores: 1.Queima de cana-de-açúcar 2.Pressão arterial 3.Poluição do ar 4.Marcadores inflamatórios 5.Estresse oxidativo 6.Teste de esforço

USP/FM/DBD-506/10 


\section{Agradecimentos}

Permitam-me dividir meus agradecimentos, não por hierarquia, mas por diferenças em tempos e contextos, sendo, entretanto, todos fundamentais. Agradeço primeiramente a Deus, pela nossa existência

Agradeço a meus familiares e amigos pela cumplicidade, confiança e por sempre torcerem pelo meu sucesso. Assim, um sincero muito obrigado a:

- A Antonio e Therezinha, meus pais;

- A Paiva, meu companheiro;

- A Marina e Gabriel, meus tesouros;

- A Tekinha, Ana, Ró e Ago, meus queridos irmãos;

- A minha amada avó Alzira (in memorian);

- Ao meu saudoso primo Zé (in memorian);

- A querida tia Margarida (in memorian), que nos deixou recentemente;

- A meus amigos: Cacá, Guto, Soan, Claudia Falcão, Roberto Carlos, João Carlos.

Agradeço à Direção da Fundacentro, órgão de pesquisa do Ministério do Trabalho e onde estou inserida profissionalmente, pelo grande apoio a mim fornecido em todas as fases do meu trabalho.

- Aos meus colegas de trabalho, em especial, Robson Silva, Maria Maeno, Cristiane Queiroz, Marcos Bussasco, Daltrine e Arline. 
Agradeço a Fenaesp por ter tornado possível este trabalho.

Agradeço a Diretoria da Usina Santa Maria, em especial ao Sr. José Pillon e seus representantes por terem facilitado a realização deste trabalho nas dependências da empresa.

- Obrigada aos trabalhadores participantes deste trabalho, pois sem vocês não teríamos chegado aqui.

Agradeço também a todas as pessoas, representadas individualmente ou por equipes, ligadas a Universidade de São Paulo, que contribuíram efetivamente para a realização deste trabalho. Saibam que temos aqui o resultado de um trabalho coletivo com a participação fundamental de cada um individualmente:

- Prof. Francisco Vargas Suso e equipe da Disciplina de Pnuemologia

- Prof. Mário Terra Filho, um agradecimento especial

- Aos Drs. André Albuquerque, João Marcos Salge e equipe da Função Pulmonar e Ergoespirometria do Instituto do Coração

- A Profa. Naomi K. Karagawa e equipe do Laboratório de Poluição Atmosférica Exeprimental da Faculdade de Medicina da USP

- A Tânia Markourakis do Departamento de Farmacologia da Faculdade de Medicina da USP

- Aos colegas radiologistas, Drs. Rodrigo Caruso Chate, Carmem Fujita e Claudia Maria Figueiredo

- A equipe da Unidade de Reabilitação Cardiovascular e Fisiologia do Exercício do Instituto do Coração, sob coordenação do Prof. Carlos Eduardo Negrão e a Profa. Maria Urbana 
- Dr. César José Grupi e equipe da unidade da Seção de Monitorização Ambulatorial do serviço de Eletrocardiografia do instituto do Coração

- Dr. Dante Marcelo Artigas Giorge e equipe do Laboratório de Monitorização da Pressão Arterial do Instituto do Coração

- A Dra Célia Maria Cassaro Strunz e equipe do Laboratório de Análise Clínicas do Instituto do Coração

- Ariadne Negrini

- A Prof. ${ }^{a}$ Dirce Maria Trevisan Zaneta do Departamento de Epidemiologia da Faculdade de Saúde Pública - USP

- A banca de qualificação composta pelos doutores Alfésio Braga, André Albuquerque e Carlos Jardim

- Aos amigos e colegas da disciplina de Pneumologia: Milena, Regina, Daniel, Elisa, Gustavo, Rozane, Milton e Ruth

- A Marcos Paiva Matos pela avaliação ambiental

- Ao Prof. Ubiratan de Paula Santos, o Bira, meu orientador, sempre firme e exigente, mas também sempre presente e parceiro. 
"Cem vezes todos os dias lembro a mim mesmo que minha vida interior e exterior, depende dos trabalhos de outros homens, vivos ou mortos, e que devo esforçar-me a fim de devolver na mesma medida que recebi."

Albert Einstein 


\section{SUMÁRIO}

Lista de abreviaturas

Lista de figuras

Lista de tabelas

Resumo

Sumary

1 INTRODUÇÃO

1.1 O processo de produção do corte de cana manual e suas repercussões na saúde do trabalhador

1.2 Exercício físico em condições adversas 4

1.2.1 Exercício físico em ambiente com temperatura elevada 4

1.2.2 Exercício físico na presença de poluentes 9

$\begin{array}{llr}1.3 & \text { Objetivos } & 15\end{array}$

2 MÉTODOS

$\begin{array}{lll}2.1 & \text { Indivíduos avaliados } & 17\end{array}$

$\begin{array}{lll}2.2 & \text { Desenho do estudo } & 18\end{array}$

$\begin{array}{lll}2.3 & \text { Avaliação das condições de trabalho } & 18\end{array}$

2.4 Caracterização da exposição à material particulado, temperatura e umidade relativa do ar

2.5 Avaliação do Índice de Sobrecarga Térmica 21 
2.6 Procedimentos observados para avaliação individual 23

$\begin{array}{lll}2.7 & \text { Exames realizados } & 24\end{array}$

$\begin{array}{ll}\text { 2.7.1 Exame clínico } & 24\end{array}$

$\begin{array}{ll}\text { 2.7.2 Exames complementares } & 25\end{array}$

$\begin{array}{lll}2.8 & \text { Análise estatística } & 41\end{array}$

$3 \quad$ RESULTADOS $\quad 43$

3.1 Caracterização das condições de trabalho 43

3.2 Caracterização ambiental do material particulado, temperatura e umidade relativa do ar $\quad 45$

3.3 Avaliação do Índice de sobrecarga térmica 46

$\begin{array}{lll}3.4 & \text { Avaliação dos trabalhadores } & 48\end{array}$

4 DISCUSSÃO

$5 \quad$ LIMITAÇÕES $\quad 91$

6 CONCLUSÕES 93

$\begin{array}{lll}7 & \text { ANEXOS } & 95\end{array}$

8 REFERÊNCIAS 114 


\section{LISTA DE ABREVIATURAS}

Co- $\quad$ Monóxido de Carbono

$\mathrm{CO}_{2^{-}} \quad$ Dióxido de Carbono

$\mathrm{NO}_{2}^{-} \quad$ Dióxido de Nitrogênio

$\mathrm{NO}_{x^{-}} \quad$ Óxido de Nitrogênio

DPOC- Doença Pulmonar Obstrutiva Crônica

AVC- $\quad$ Acidente Vascular Cerebral

PTS- Partícula Total em Suspensão

MP- $\quad$ Material Particulado

INSS- Instituto Nacional de Seguridade Social

NR15- Norma Regulamentadora 15

IBUTG- Índice de Bulbo Úmido Termômetro de Globo

Tg- Termômetro de Globo

Tbn- $\quad$ Termômetro de Bulbo Úmido

Tbs- $\quad$ Termômetro de Bulbo Seco

INCOR- Instituto do Coração

HCFMUSP- Hospital das Clínicas da Faculdade de Medicina da Universidade de São Paulo

ANSM- Atividade Nervosa Simpática Muscular

FSM- $\quad$ Fluxo sanguíneo muscular

TCAR- Tomografia Computadorizada de Alta Resolução

PFP- $\quad$ Prova de Função Pulmonar

TC6M- Teste de Caminhada de 6 Minutos

PCR- Proteína C Reativa 
CPK- Creatinina Fosfoquinase

AST- $\quad$ Aspartato Aminotransferase

ALT- Alanino Aminotransferase

DHL- Desidrogenase Láctica

ISE- Eletrodo Íon Seletivo

Circ. Abd.- Circunferência Abdominal

GPX- Glutationa Peroxidase

GR- $\quad$ Glutationa Redutase

SOD- Superóxido Desmutase

GST- $\quad$ Glutationa Transferase

MDA- Malondialdeiodo

HPLC- Cromatografia Líquida de Alta Eficiência

ATS- $\quad$ American Thoracic Society

ERS- European Respiratory Society

$V_{E F}{ }^{-} \quad$ Volume Expiratório Final no primeiro minuto

CVF- $\quad$ Capacidade Vital Forçada

$\mathrm{FEF}_{25-75 \%^{-}} \quad$ Fluxo Expiratório Forçado

CVL- $\quad$ Capacidade Vital Lenta

Cl- Capacidade Inspiratória

Raw- Resistência das Vias Aéreas

Sgaw- Condutância das Vias Aéreas

CRF- $\quad$ Capacidade Residual Forçada

CPT- Capacidade Pulmonar Total

VR- $\quad$ Volume Residual

DLCO- Difusão de Monóxido de Carbono 
TC6M- Teste de Caminhada de Seis Minutos

MAPA- Monitoramento Ambulatorial da Pressão Arterial

SDNN- Desvio Padrão dos Intervalos RR Normal

SDANN- Desvio Padrão das Médias dos Intervalos RR Normal

rMSSD- Raiz Quadrada da Média da Diferença entre os Intervalos NN

Adjacentes

LH- Baixa Freqüência

HF- $\quad$ Alta Freqüência

TCSI- Teste de Caminhada Shuttle Incremental

FC- $\quad$ Freqüência Cardíaca

PA- Pressão Arterial

PAS- $\quad$ Pressão Arterial Sistólica

PAD- $\quad$ Pressão Arterial Diastólica

PAM- Pressão Arterial Média

IMC- I Índice de Massa Corpórea

VFC- Variabilidade da Freqüência Cardíaca

CAPPESQ- Comissão de Ética para Análise de Projeto de Pesquisa do Hospital das Cínicas da Faculdade de Medicina de São Paulo

Me- Mediana

IIQ- Intervalo Interquartil

M- Média

DP- Desvio Padrão

TP- $\quad$ Tempo de Protrombina

TT- $\quad$ Tempo de Trombina

$\mathrm{SPO}_{2^{-}} \quad$ Saturação de Oxigênio 
FR- $\quad$ Freqüência Respiratória

MMII- Membros Inferiores

Inc/min- Incursões por minuto

$\mathrm{VO}_{2}$ pico- Consumo de Oxigênio no Pico

Rep- Repouso

$\mathrm{PETCO}_{2-}$ Pressão Expiratória Final de Dióxido de Carbono

$\mathrm{PETO}_{2-} \quad$ Pressão Expiratória Final de Oxigênio

RER- Razão de Troca Respiratória

Ve min- Volume Minuto

OMS- Organização Mundial de Saúde

CIIAGRO- Centro Integrado de Informações Agrometereológicas

ppb- $\quad$ partes por bilhões

TMC- Teste mucocilial

TGO- Transaminase Glutâmica Oxalacética

TGP- $\quad$ Transaminase Glutâmica Pirúvica

TTPA- Tempo de Tromboplastina Parcial Ativado

INR- Razão Normalizada Internacional

VHS- Velocidade de Hemosedimentação 


\section{LISTA DE FIGURAS}

Figura 1- Foto do cortador de cana, no canavial, usando roupas sobrepostas

Figura 2- Monitor de material particulado $\mathrm{MP}_{2,5}$ (DustTrak) e Termohigrômetro

Figura 3- Monitor de Stress Térmico

Figura 4- Cronograma de avaliações

Figura 5- Cortador durante o exame de Microneurografia

Figura 6- Cortador durante o exame de Plestimografia de Oclusão Venosa

Figura 7- Cortador trabalhando durante o período da safra

Figura 8- Cortador trabalhando durante o período da entressafra

Figura 9- Concentração de PCR nos períodos da safra e entressafra

Figura 10- Concentração de TT e TP nos períodos da safra e entressafra

Figura 11- Atividade das enzimas antioxidantes nos períodos da safra e entressafra

Figura 12- Concentração de MDA nos períodos da safra e entressafra

Figura 13- Pressão arterial durante o MAPA, nos períodos da safra e entressafra

Figura 14- Pressão arterial na Ergoespirometria, nos períodos da safra e da entressafra

Figura 15- Ergoespirometria por isocarga nos períodos da safra e entressafra

Figura 16- Imagem radiológica (TCAR) de um cortador 
Figura 17- Teste de transporte muco ciliar nos períodos da safra e entressafra

Figura 18- Contagem de micronúcleos nos períodos da safra e entressafra

Figura 19- Amostra de células da mucosa oral sem e com a presença de Micronúcleos. 


\section{Lista de Tabelas}

Tabela 1- Concentração de $\mathrm{MP}_{2,5}$, temperatura e umidade no canavial, nos períodos da safra e entressafra

Tabela 2- $\quad$ Níveis de IBUTG no canavial, medidos no dia 25/11/2007

Tabela 3- Níveis de IBUTG no canavial, no horário de maior sobrecarga térmica (11h 10 min ás 12 h 10 min) do dia 25/11/2007

Tabela 4- Distribuição dos cortadores de cana por número de safras trabalhadas

Tabela 5- Freqüência de sintomas entre os participantes durante os períodos da safra e entressafra

Tabela 6- Características gerais dos trabalhadores durante os períodos da safra e entressafra

Tabela 7- Avaliação laboratorial dos trabalhadores, nos períodos da safra e entressafra

Tabela 8- Atividade das enzimas antioxidantes e o nível de malondialdeido, nos períodos da safra e entressafra

Tabela 9- Resultado da Prova de função pulmonar completa, nos períodos da safra e entressafra

Tabela 10- Resultado do Teste de caminhada de seis minutos, nos períodos da safra e entressafra

Tabela 11- Avaliação do Monitoramento ambulatorial da pressão arterial, nos períodos da safra e entressafra

Tabela 12- Avaliação do Eletrocardiograma de 24 horas (Holter 24 hs), nos períodos da safra e entressafra 
Tabela 13- Distribuição dos cortadores segundo dados da Ergoespirometria nos períodos da safra e entressafra

Tabela 14- Associação da redução da VFC e ativação simpática com alterações na pressão arterial

Tabela 15- Número de ocorrências de alterações na TCAR de tórax entre os cortadores de cana 


\section{Avaliação cardiovascular e respiratória em um grupo de cortadores de cana-de-açúcar queimada no estado de São Paulo}

\section{Resumo}

Introdução: O Brasil é o maior produtor mundial de cana-de-açúcar e de seus produtos, açúcar e etanol. A colheita predominantemente manual, expõe o trabalhador a uma série de riscos á saúde, como esforço físico, calor e poluentes, decorrentes da queima da palha da cana. Objetivos: Avaliar a ocorrência de efeitos cardiovasculares e respiratórios e possíveis mecanismos implicados nos mesmos, associados ao trabalho no corte de cana-de-açúcar queimada. Métodos: Vinte e oito cortadores de cana-de-açúcar, brancos, sexo masculino, hígidos, residentes em uma região do interior do Estado de São Paulo, foram submetidos à avaliação através de marcadores sanguíneos, monitoramento ambulatorial da pressão arterial, eletrocardiograma de 24 horas, prova de função pulmonar, tomografia de tórax de alta resolução, testes de caminhada de seis minutos, Incremental (Schuttle Test), e do exercício cardiopulmonar, medida direta da atividade nervosa simpática no nervo fibular, medida do fluxo sanguíneo muscular no antebraço, teste de transporte mucociliar e avaliação de efeitos genotóxicos (análise de micronúcleos na mucosa oral), durante o período de trabalho no corte de cana queimada (Safra) e quatro meses após, quando desempenhavam outras atividades. Foram realizadas medições de material particulado $\left(\mathrm{PM}_{2.5}\right)$ e de variáveis climáticas. Os dados obtidos foram comparados através de testes estatísticos para medidas repetidas. Para avaliar o efeito do trabalho na safra e de outras 
variáveis, foram realizadas análises de regressão linear multivariada. Para 0 Teste de micronúcleo utilizou-se um grupo controle de 17 indivíduos da região, mesma faixa etária que nunca tinham trabalhado no corte de cana. Resultados: Os participantes do estudo tinham $31 \pm 6.3$ anos e trabalhavam em média 9.8 \pm 8.4 anos no corte de cana-de-açúcar queimada. Durante a safra a concentração de material particulado foi mais elevada no canavial $(84,69 \pm 23,90$ vs $53,20 \pm 14,82, p<0.001)$ e o índice de sobrecarga térmica alcançou níveis elevados $\left(28,4^{0} \mathrm{C}\right)$. O trabalho durante a safra esteve associado a maiores níveis de Creatinina Fosfoquinase (mediana e intervalo interquartil), 136.5(108.5-216) vs 104.5 (77.5-170.5)U/L; $\mathrm{p}=0.001$, Glutationa Peroxidase $(55.1 \pm 11.8 \quad$ vs $\quad 39.5 \pm 9.6 \mathrm{Ug} / \mathrm{Hb} ; \quad \mathrm{p}<0.001), \quad$ Malonaldeido $(0.08 \pm 0.01 \mathrm{vs} 0.07 \pm 0.01 \mu \mathrm{m} / \mathrm{ml} ; \mathrm{p}=0.033)$, pressão sanguínea arterial sistólica de 24 horas (120.14 \pm 10.31 vs $117.00 \pm 9.96 \mathrm{mmHg} ; \mathrm{p}=0.047)$. A pressão diastólica aumentou durante 0 teste de exercício durante a safra $(\Delta 11.12 \mathrm{mmHg} ; \mathrm{p}<0,001)$. Na Tomografia de alta resolução do tórax houve um percentual elevado de micronódulos centrolobulares $(70,90 \%)$ e espessamento da parede brônquica $(51,61 \%)$. O tempo de transporte mucociliar foi maior na safra $(23,4 \pm 14$ vs $15,9 \pm 6,7, p=0,001)$. A contagem de micronúcleos entre os cortadores foi maior que no grupo controle, no período da safra $(7,89 \pm 5,81$ vs $4,24 \pm 4,51, p=0,010)$ e no período da entressafra $(11,82 \pm 11,08$ vs $4,24 \pm 4,51$, $p=0,017)$. A redução da variabilidade da freqüência cardíaca e aumento da atividade simpática estiveram significativamente associados a aumento da pressão arterial. Conclusão: $O$ trabalho durante a safra se associou à alterações cardiovasculares (aumento da pressão arterial no repouso e no exercício), possivelmente mediada por estresse oxidativo e desbalanço 
autonômico, alterações respiratórias (alterações de imagens e transporte mucociliar) e aumento de micronúcleos.

Palavras-chaves: Queima de cana-de-açúcar, poluição e pressão arterial, poluição do ar, poluição e marcadores inflamatórios, poluição e estresse oxidativo, poluição e teste de esforço cardiopulmonar. 


\section{Sumary}

Cardiovascular and respiratory evaluation in a group of burnt sugarcane harvesters in São Paulo state

Introduction: Brazil is the world's largest producer of sugarcane and its products, sugar and ethanol. The predominantly manual harvest exposes workers to a series of health risks from sugarcane burning, such as physical exertion, heat and pollutants. Objectives: To evaluate the occurrence of cardiovascular and respiratory effects and possible mechanisms associated with them in burnt sugarcane harvesting work. Methods: Twenty-eight sugarcane harvesters, all Caucasian, healthy, male, residing in the countryside of São Paulo state, were evaluated through blood markers, twenty-four hours ambulatory blood pressure monitoring, twenty-four hours eletrocardiography Holter monitoring, pulmonary function testing, chest HRCT, six-minute walk tests, shuttle walk test, cardiopulmonary exercise testing, muscle sympathetic nerve activity in the peroneal nerve, muscle blood flow in the forearm, mucociliary transport test and evaluation of genotoxic effects (analysis of micronuclei in the oral mucosa) during burnt sugarcane harvest period and four months later, when the workers performed other activities. The study measured particle size $\left(\mathrm{PM}_{2.5}\right)$ and climate variables. The obtained data were compared using statistical tests for repeated measurements. Multivariate linear regression analyses were used to evaluate the effect of work during the harvest period and of other variables. For the micronucleus test, a control group was used consisting of 17 local individuals, in the same age range, who had never worked in sugarcane harvesting. Results: Participants had a mean age of $31 \pm 6.3$ years 
and had worked for an average of $9.8 \pm 8.4$ years on the harvesting of burnt sugarcane. During the harvest period, the concentration of particulate matter was higher in the sugarcane field $(84.69 \pm 23.90$ vs. $53.20 \pm 14.82, p<0.001)$ and the thermal overload index reached high levels $\left(28.4^{\circ} \mathrm{C}\right)$. Work during the harvest period was significantly associated with high serum levels of Creatine Kinase (median and interquartile range), 136.5 (108.5-216) vs. 104.5 (77.5170.5) $\mathrm{U} / \mathrm{L} ; \mathrm{p}=0.001$, Glutathione Peroxidase (55.1 \pm 11.8 vs. $39.5 \pm 9.6 \mathrm{Ug} / \mathrm{Hb}$; $\mathrm{p}<0.001)$, Malonaldehyde $(0.08 \pm 0.01$ vs. $0.07 \pm 0.01 \mu \mathrm{m} / \mathrm{ml} ; \mathrm{p}=0.033)$, and 24 hour systolic blood pressure (120.14 \pm 10.31 vs. $117.00 \pm 9.96 \mathrm{mmHg}$; $p=0.047$ ). Diastolic blood pressure increased during the cardiopulmonary test for the harvest period $(\Delta 11.12 \mathrm{mmHg} ; \mathrm{p}=0.001)$. In chest HRCT we noted high prevalence of centrilobular micronodules (70.90\%) and bronchial wall thickening (51.61\%). Mucociliary transport time was greater during the harvest period (23.4 \pm 14 vs. $15.9 \pm 6.7, p=0.001)$. The micronucleus count among harvesters was higher than for the control group, during the harvest period $(7.89 \pm 5.81$ vs. $4.24 \pm 4.51, p=0.010)$ and in the non-harvest period (11.82 \pm 11.08 vs. $4.24 \pm 4.51$, $p=0.017)$. The reduction in heart rate variability and higher sympathetic activity were significantly associated with higher blood pressure. Conclusion: Work during the harvest season was associated with cardiovascular changes (higher blood pressure at rest and during exercise), which may possibly be linked to oxidative stress and autonomic imbalance, as well as respiratory changes (changes in imaging and mucociliary transport) and increased micronuclei.

Keywords: Sugarcane burning, pollution and blood pressure, pollution and inflammation markers, pollution and oxidative stress, pollution and cardiopulmonary exercise test. 



\section{INTRODUÇÃO}

\begin{abstract}
Este trabalho foi motivado pelo relato de óbitos não esclarecidos de cortadores de cana-de-açúcar no Estado de São Paulo e pela inexistência, até o momento, de estudos que avalie efeitos cardiorespiratórios nesta categoria profissional. No Brasil, estima-se em cerca de 500 mil o número de trabalhadores do setor sucroalcooleiro.
\end{abstract}

O Brasil é o maior produtor mundial de açúcar e álcool, possuindo aproximadamente sete milhões de hectares de área plantada de cana-deaçúcar. São Paulo é o maior produtor nacional, contando com uma área cultivada de 4,88 milhões de hectares, $64 \%$ da área total do país. ${ }^{1} \mathrm{~A}$ produção nacional na safra de $2008 / 09$ foi de 568,9 milhões de toneladas de cana-de-açúcar ${ }^{1}$, sendo que o estado de São Paulo, produziu 346 milhões $(60 \%)$ de toneladas ${ }^{2}$.

A cultura de cana tem um importante papel na economia do país, especialmente nos últimos anos, já que o Brasil desenvolveu tecnologia e é pioneiro na produção e utilização do álcool como biocombustível, uma alternativa renovável menos poluente que os derivados do petróleo, levando o interesse pelo produto a proporções internacionais ${ }^{3}$. O consumo mensal de álcool no país vem crescendo progressivamente e desde abril 2008 superou o consumo de gasolina ${ }^{1}$.

Em decorrência disto, o setor sucroalcooleiro vem crescendo e atingindo produções recordes. Em São Paulo a cana-de-açúcar é há muitos anos a atividade mais importante na demanda total pela força de trabalho no 
setor agrícola. ${ }^{4}$ Estima-se que atualmente cerca de 160 mil pessoas trabalhem no setor sucroalcooleiro no estado de São Paulo 5 .

Dentro da perspectiva de crescimento vertiginoso do setor sucroalcooleiro, para atender tanto o mercado interno como o externo e manter-se na liderança na produção mundial de cana e álcool, o processo envolvido na cultura do produto passou por mudanças significativas nos últimos anos, com um aumento progressivo da produtividade. ${ }^{6}$

Ainda na década de 80, com o incentivo do Programa Pro-álcool, cresce no país o investimento no setor, levando à ampliação da área plantada, aumentando o número de novas usinas e empregos em toda a cadeia produtiva ${ }^{2,6}$. As usinas passaram a investir em tecnologias avançadas, com modernização crescente de máquinas e equipamentos, visando aumentar a quantidade e melhorar a qualidade do produto.

\subsection{O processo de produção do corte de cana manual e suas repercussões na saúde do trabalhador}

O processo manual de corte é uma atividade laboral que impõe o trabalhador a uma carga física intensa, com execução de movimentos rápidos, repetitivos e em sobrecarga com o corpo. O ciclo de trabalho pode ser assim resumido: abraçar um monte de cana (com 3-10 canas), golpear com o facão, uma ou várias vezes até cortá-los, o mais próximo possível do solo, preservando a raiz. Para isto, o trabalhador faz uma série de torções e flexões do tronco ao se agachar, realiza movimentos contínuos, vigorosos e 
repetitivos com os braços, através dos golpes com o facão. Ainda, realiza caminhada pelo canavial com os montes de cana cortados, arrumando-os em fileiras, nos eitos ou ruas estabelecidas para cada cortador. A cana amontoada é carregada mecanicamente em caminhões, que a transporta até a usina.

O pagamento do salário do cortador por produção incentiva o incremento do ritmo de trabalho, para manter a produtividade e os rendimentos dela decorrente $e^{6-8}$.

Ainda não se pode esquecer que o esforço físico exigido na atividade sofre interferências de outros fatores alheios ao controle do empregado, como por exemplo, o tipo e qualidade da cana (a cana mais nova e a cana "em pé", cultivada em terrenos regulares são mais fáceis de cortar) que não são levados em conta no pagamento por produção ${ }^{7,9,10}$.

Segundo Alves ${ }^{6}$, na década de 50 o trabalhador cortava em média 3 toneladas de cana por dia. Na década de 80, para manter um ganho equivalente, esta produção duplicou, sendo que no final dos anos 90 e na atual década a produtividade média por trabalhador/dia, chega a 10 toneladas, muito embora o valor ganho seja equivalente ao da década de 80 . Este autor $^{6}$ compara o trabalho do cortador de cana ao de um corredor fundista, porque o trabalhador que obtém maior produtividade, não necessariamente é o que possui maior massa muscular e sim o que possui maior resistência física para desempenhar aquela tarefa.

Entretanto, em geral o atleta desenvolve um exercício físico de modo organizado, com preparação prévia e especificações de tempo de 
treinamento, condicionamento progressivo, existência de pausas, estimativa de balanço nutricional e calórico para a atividade física a ser desempenhada ${ }^{11,12}$, o que não ocorre com o cortador de cana. Este trabalhador além de não ter qualquer preparo prévio do ponto de vista de condicionamento físico ou aporte nutricional ainda executa seu trabalho de modo intensificado, sem pausas para que o organismo se recupere ${ }^{6,13}$. Para Langowski ${ }^{14}$, apesar destes trabalhadores serem verdadeiros atletas não recebem a mesma contrapartida em termos de atenção e cuidados.

Além destes aspectos, na maior parte do Estado, os cortadores têm registro temporário em carteira, com redução de direitos, quando comparados a outras categorias profissionais com registro regular ${ }^{15}$.

\subsection{Exercícios físicos em condições adversas}

\subsubsection{Exercício físico em ambiente com temperatura elevada}

O trabalhador ao chegar ainda cedo no canavial enfrenta em seu ambiente de trabalho, temperatura bastante elevada, decorrente do aquecimento pela queima da cana e que pode se intensificar durante o dia pelo ação solar' ${ }^{9}$. Deste modo, o calor pode ser um fator de risco que, somado ao exercício excessivo, pode levar a hipertermia e desidratação ${ }^{16,17}$.

O desconforto térmico e a hipertemia também são aumentados pelo uso de vestimentas grossas e sobrepostas, uma vez que se faz necessária 
proteção para todo corpo: botina, perneira de couro até o joelho, calças grossas, camisa de manga comprida com mangote, luvas, lenço no pescoço e chapéu (Figura 1). Estas vestimentas dificultam a dissipação de calor, aumentado a possibilidade de ocorrência de hipertemia ${ }^{17,18}$.

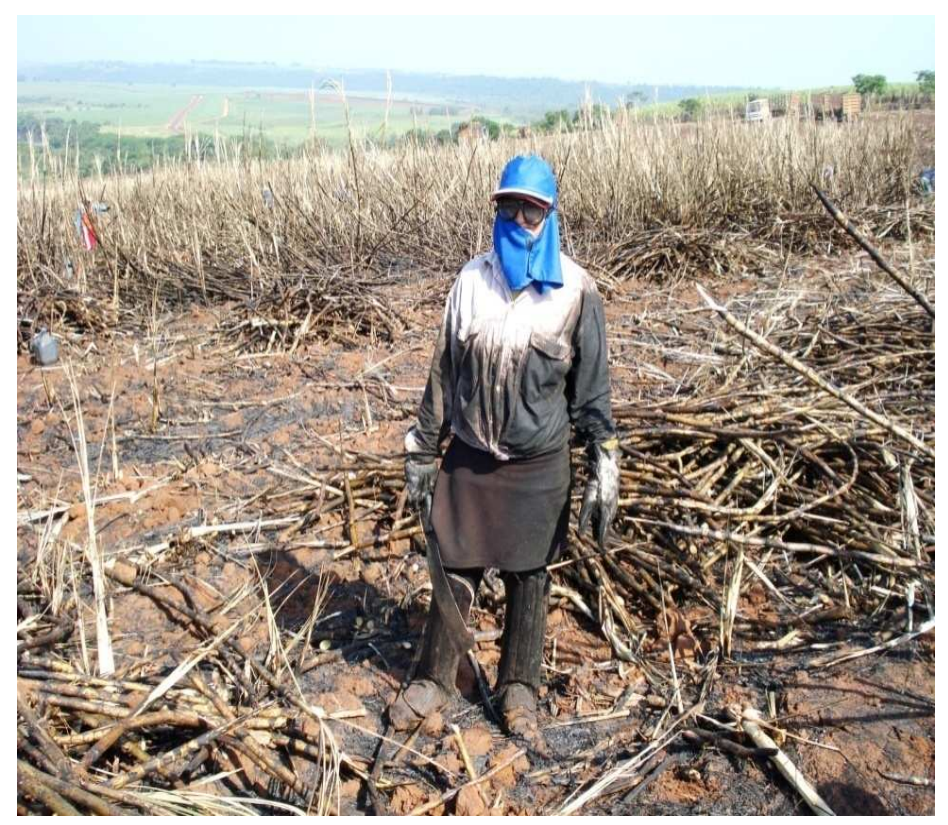

Figura 1 - Cortador de cana no canavial, usando roupas sobrepostas

Ao longo da jornada para compensar a perda líquido pelo suor, o cortador ingere bastante água ${ }^{9,13}$. A prática das usinas em fornecer "repositores" é feita de maneira igual para todos, não sendo possível avaliar se atende às variações de cada indivíduo.

Durante o exercício físico o organismo aumenta o consumo de oxigênio para suprir as necessidades dos músculos em movimento. Este processo leva a uma série de respostas orgânicas, no sentido de manter a homeostasia interna ${ }^{19,20}$. Estas respostas são reguladas tanto a nível central, como a nível periférico. O Sistema Nervoso Central induz a alterações no 
sistema nervoso autônomo, com estimulação da atividade simpática e diminuição da atividade parassimpática, durante o exercício, atuando assim no sistema cardiovascular levando, entre outras alterações, a aumento da freqüência cardíaca e do volume sistólico, com conseqüente aumento do débito cardíaco, assegurando maior aporte de oxigênio e nutrientes aos músculos durante o exercício ${ }^{19,21 .}$

Quando a carga de exercício é constante e de intensidade moderada o organismo se adapta a esta nova condição de maneira que os efeitos benéficos do exercício físico são sentidos e se associam principalmente a menor prevalência de doenças crônico-degenerativas, como eventos cardiovasculares $^{22-24}$.

Entretanto em condições de exercício físico vigoroso por período prolongado o organismo não consegue manter a homeostasia e um quadro patológico pode se instalar ${ }^{20,21,25,26}$. No caso do atleta esta situação é denominada de "Síndrome de Overtraining"25, 27, 28.

A Síndrome de Overtraining é compreendida por sinais e sintomas caracterizados por diminuição da performance, fadiga, alterações do sono, diminuição de peso, aumento dos níveis séricos de lactato, alterações hormonais, imunológicas hematológicas e psicológicas ${ }^{25,29,30}$.

Entretanto, não existem marcadores específicos que caracterizem a presença da síndrome e os seus mecanismos fisiopatológicos não estão completamente esclarecidos ${ }^{29,31-33}$.

É provável que na atividade de corte de cana devido ao ritmo de trabalho intenso, os ajustes fisiológicos que ocorrem em resposta ao 
exercício físico não consigam dar suporte à demanda do organismo para manter o equilíbrio interno, e com isto resposta anômala e/ou patológica passe a ocorrer, refletindo em níveis diversos de fadiga e insuficiência dos músculos envolvidos no trabalho e de órgão alvos exigidos acima do limite e analogamente ao que ocorre com os atletas, estes trabalhadores podem desenvolver quadro semelhante a "Síndrome de Overtraining".

A fadiga, segundo Rossi $\mathrm{L}^{34}$, pode ser definida como um conjunto de alterações causadas pelo trabalho ou exercício prolongado, que leva a uma diminuição da capacidade funcional de manter o rendimento esperado. Entre os cortadores de cana é freqüente a referência a fadiga ${ }^{13}$.

Agravando ainda mais a situação destes trabalhadores outras manifestações patológicas podem também estar presentes decorrentes da ação do calor durante o corte de cana.

As manifestações clínicas da exposição ao calor são em geral inespecíficas e de caráter progressivo ${ }^{17}$. Inicialmente aparece o edema de membros inferiores, devido à vasodilatação periférica. Em seguida é comum a aparição de câimbras, que ocorre pelo desequilíbrio hidroeletrolítico, sendo este sintoma um alerta sobre a possibilidade de lesões mais graves decorrentes do calor excessivo ${ }^{18,35}$. Se o quadro evoluir, sintomas de exaustão com a presença de bradicardia, hipotensão e síncope podem se manifestar e finalmente um quadro de hipertemia poderá se instalar podendo levar à morte, se medidas terapêuticas não forem tomadas a tempo ${ }^{17,35}$.

O uso de roupas sobrepostas pode agravar a aparição de sintomas de desconforto térmico ${ }^{17,18}$. 
Todo este processo que demanda esforço físico excessivo e que pode estar associado à hipertermia e desbalanço eletrolítico é reconhecido como causa de lesão muscular, com rabdomiólise, podendo levar a insuficiência renal aguda ${ }^{36,37}$, outra conseqüência que não pode ser descartada no trabalho realizado no corte de cana.

O perfil de morbidade dos cortadores reflete as condições de trabalho e exposição a fatores de riscos a que os mesmos estão submetidos. As queixas de sintomas inespecíficos como câimbras, dores nas pernas, cefaléia, cansaço físico e distúrbios visuais, associados a problemas osteomusculares predominam, conforme relatos de diversos estudos ${ }^{9,13,14}$.

Para a pesquisadora Silva $\mathrm{MAM}^{15}$, o esforço físico imposto ao cortador encurta o seu ciclo de trabalho na atividade, devido à aparição de afecções de coluna e tendinites.

Estudo realizado em um grupo de cortadores de cana da região de Ribeirão Preto revelou que $23 \%$ deles consideram o esforço físico no trabalho como um risco a sua saúde ${ }^{13}$.

Em outros países que realizam o corte manual de cana o quadro de morbidade semelhante é também percebido, predominando doenças osteomusculares, traumas agudos e doenças infecto-parasitárias ${ }^{38-41}$. 


\subsubsection{Exercício físico na presença de poluentes}

No Brasil é comum a prática de se atear fogo aos canaviais, com o objetivo de facilitar e agilizar o corte, e assim aumentar a produtividade da colheita. Historicamente as queimadas fazem parte do processo de produção de cana de açúcar, iniciando-se no período da introdução da cultura no país e perpetuando-se até os dias atuais ${ }^{2,6}$.

A queima, embora programada para ocorrer no máximo antes das 22 horas do dia anterior, ás vezes ocorre poucas horas antes do corte, não sendo incomum o trabalhador adentrar no canavial com temperatura elevada e com fumaça ${ }^{7}$.

Além do aumento da temperatura e de risco de incêndio para áreas próximas, a queima da cana representa uma fonte importante de emissão de partículas e gases poluentes para atmosfera ${ }^{42}$ que influenciam direta ou indiretamente a saúde e o bem estar da população trabalhadora e residente das áreas próximas.

A queima da biomassa é uma das principais fontes de emissão de gases, como monóxido de carbono $(\mathrm{CO})$, dióxido de carbono $\left(\mathrm{CO}_{2}\right)$, metano, dióxido de nitrogênio $\left(\mathrm{NO}_{2}\right)$, $\mathrm{NOx}$, hidrocarbonetos e material particulado (MP). Estima-se que anualmente seja emitido cerca de 120-510 milhões de toneladas de carbono e 36-150 milhões MP decorrente da queima de biomassa nos trópicos ${ }^{42}$. 
Diversos trabalhos publicados demonstram que a inalação de material particulado e outros poluentes estão associados a efeitos cardiorespiratórios agudos e crônicos ${ }^{43-52}$.

O material particulado compreende uma mistura de partículas em suspensão no ar, de variável tamanho, composição e origem ${ }^{49,53}$. As chamadas partículas grandes (coarse fraction) compreendem partículas com mediana de diâmetro aerodinâmico entre 2,5 e 10 micrometros $(\mu \mathrm{m})$, que penetram e se depositam em regiões mais altas do sistema respiratório até as vias aéreas inferiores. As partículas finas denominadas de $\mathrm{MP}_{2,5}$, possuem mediana de diâmetro aerodinâmico menor que 2,5 $\mu \mathrm{m}$ atingindo as regiões mais inferiores do trato respiratório e região alveolar, sendo consideradas mais danosas ${ }^{49,54,55}$.

A inalação de partículas desencadeia inflamação pulmonar que pode produzir tanto efeitos agudos, que se manifestam em horas ou dias (aumento da exacerbação de asma e DPOC, do risco de arritmia, de infarto do miocárdio e AVC) ${ }^{48-50,52}$ como crônicos, que se desenvolvem ao longo dos anos, como a aceleração da aterosclerose, aumento do risco de óbitos por doenças cardiovasculares e respiratórias e aumento da incidência de câncer de pulmão ${ }^{49,51,56,57}$.

A origem do material particulado é outro fator que também influencia na resposta do organismo ${ }^{49,58}$ sendo que a maioria dos estudos relacionados à efeitos a saúde decorrente da poluição urbana, são de origem industrial ou veicular. Em relação à poluição ambiental originada da queima da cana os estudos são em menor número e mais voltados para os efeitos 
respiratórios ${ }^{43,48,59}$ com poucos estudos abordando os efeitos cardiovasculares $^{58,60}$. Estudo recém publicado $^{60}$ encontrou aumento de 12,5\% na admissão hospitalar por hipertensão associado à elevação de $10 \mu \mathrm{gm}^{3}$ de partículas totais em suspensão (PTS) durante o período de queima de cana-de-açúcar em uma cidade brasileira.

No Brasil, diversos estudos têm demonstrado alterações respiratórias entre a população residente á áreas próximas aos canaviais, onde ocorre a queima da cana ${ }^{43,48,59,61}$.

Arbex ${ }^{48}$, em estudo de série temporal, realizado na cidade de Araraquara, evidenciou que durante o período de queima de cana de açúcar ocorreu um aumento de $11,6 \%$ o número de admissões hospitalares por asma, associado a elevação de $10 \mu \mathrm{g} / \mathrm{m}^{3}$ de partículas totais em suspensão, persistindo aumentado até cinco dias após o evento.

Estudo realizado na cidade de Piracicaba ${ }^{43}$ mostrou um aumento de $21,4 \%$ e 31,03\% nas internações respiratórias em crianças e idosos, respectivamente, associados à elevação de $10,2 \mu \mathrm{g} / \mathrm{m}^{3}$ na concentração de $\mathrm{MP}_{2,5}$ e de $42,9 \mu \mathrm{g} / \mathrm{m}^{3}$ no $\mathrm{MP}_{10}$.

Nos Estados Unidos, estudo realizado na cidade de Houma, Louisiania, mostrou que nos meses em que ocorre a queima da palha de cana concentra o aumento de internações por asma entre a população local $^{62}$.

Para Torres Duque et al., ${ }^{63}$ em recente revisão sobre queima de biomassa em ambientes internos, existe forte evidencia da associação com 
infecções respiratórias agudas em crianças e DPOC em mulheres, decorrentes da fumaça do carvão.

Entretanto, em relação à população trabalhadora no corte de cana, até o momento são escassos as publicações sobre as possíveis alterações cardiovasculares e respiratórias.

Estudo caso-controle ${ }^{64}$ realizado na Índia encontrou um aumento de risco de câncer de pulmão entre trabalhadores da lavoura de cana, envolvidos nas atividades de preparação da lavoura, provavelmente decorrente da poeira da terra contendo sílica.

No Brasil, Bosso ${ }^{65}$ em estudo com cortadores de cana, na cidade de Ribeirão Preto, verificou um aumento de excreção urinária de hidroxipireno urinário, biomarcador de exposição a hidrocarboneto aromático, entre os trabalhadores, no período da queima de cana $\left(0,318 \mu \mathrm{mol} \mathrm{mol}^{-1}\right.$ creatinina) em relação aos mesmos trabalhadores no período fora da queima $(0,035$ $\mu \mathrm{mol} \mathrm{mol}^{-1}$ creatinina), bem como em relação a um grupo controle de trabalhadores não envolvidos em atividade de cana $\left(0,041 \mu \mathrm{mol} \mathrm{mol} \mathrm{mol}^{-}\right.$ ${ }^{1}$ creatinina). Os demais estudos, nesta categoria, estão relacionados à organização e ao ritmo do trabalho ${ }^{4,6,7,10,14,15}$ e a riscos de acidentes ${ }^{7,10,15}$.

No caso dos cortadores, deve ser levado em conta a associação entre a exposição a poluentes decorrentes da queima e o esforço físico intenso realizado durante o corte.

Estudos mostram um pior desempenho durante o exercício em situações com poluição elevada ${ }^{66,67}$. A quantidade de partículas ultrafinas que se deposita no trato respiratório durante a realização de exercícios 
moderados chega a ser cerca de 4-5 vezes superior quando comparado com o repouso em estudo realizado entre indivíduos saudáveis ${ }^{68}$.

Indivíduos submetidos a exercício na presença de poluentes podem apresentar alterações cardiorespiratórias. Um estudo, com portadores de doença coronariana estável, mostrou um risco de depressão do segmento ST três vezes maior durante a realização de teste do exercício, associado à concentração de material particulado dois dias antes do teste ${ }^{45}$. Outro estudo também encontrou depressão do segmento ST, além de aumento da freqüência cardíaca e da redução dos níveis de ativador tecidual de plasmminogênio, em um grupo de pacientes com antecedentes de infarto do miocárdio que realizaram exercícios na presença de ar poluído comparado com ar limpo ${ }^{69}$.

Dados recentes do INSS (Instituto Nacional de Seguridade Social) no país, referentes ao ano de 2007, registraram um aumento de adoecimento por doenças cardiovasculares entre trabalhadores do setor sucroalcooleiro, comparando com a população geral ${ }^{70}$.

Nos últimos anos, inúmeras denúncias têm sido realizadas, por parte de instituições públicas - Universidades, Ministério Público, Ministério do Trabalho, o Legislativo de várias esferas da Federação - de sindicatos de trabalhadores rurais e da imprensa, sobre a ocorrência de mortes de cortadores de cana, sem que causas sejam estabelecidas ${ }^{6,14}$.

É possível que esta somatória de riscos presentes na atividade laboral destes trabalhadores, esteja contribuindo para estes óbitos, porém, até o 
momento nenhum estudo foi realizado no sentido de investigar as possíveis causas e fatores relacionados a estas mortes.

Tal situação tem pressionado o setor a procurar mudanças nas condições de trabalho, de modo que em junho de 2009 foi assinado o Protocolo Agroambiental do Setor Sucroalcooleiro com o Governo Estadual, que estabelece o fim da queimada de cana em todo o país para $2017^{71}$.

Considerando a escassez de dados em cortadores de cana queimada resolvemos realizar este estudo exploratório, com um abrangente painel de indicadores que podem servir de base para esclarecer possíveis efeitos na saúde dos cortadores de cana e mecanismos implicados. 


\subsection{Objetivos}

\subsubsection{Geral}

$>$ Avaliar ocorrência e possíveis mecanismos de alterações cardiovasculares e respiratórias em um grupo de trabalhadores cortadores de cana-de-açúcar queimada, no Estado de São Paulo.

\subsubsection{Específicos}

Avaliar efeitos cardiovasculares através de avaliação do sistema nervoso autônomo, monitoramento da pressão arterial, teste do exercício cardiorrespiratório e função endotelial

Avaliar efeitos respiratórios através da prova de função pulmonar com difusão de monóxido de carbono, teste do exercício cardiorrespiratório, clearance mucociliar nasal e exame de imagem

Avaliar marcadores inflamatórios e de estresse oxidativo sanguíneos

Avaliar possíveis efeitos genotóxicos decorrentes da exposição à material particulado. 
Caracterizar as condições de trabalho, exposição ambiental a material particulado e exposição a elevada temperatura no trabalho. 


\section{MÉTODOS}

\subsection{Indivíduos avaliados}

A seleção foi feita entre trabalhadores voluntários, empregados em uma usina de açúcar e álcool, localizada na cidade de Cerquilho, há cerca de $150 \mathrm{~km}$ da cidade de São Paulo. A região é uma área predominantemente agrícola, e compreende além de Cerquilho, as cidades de Tatuí, Cesário Lange, Guareí e Tietê.

Após divulgação entre seus 500 trabalhadores, através do departamento de recursos humanos da usina, foi feito uma reunião onde compareceram 110 participantes voluntários. Destes, após explicação sobre a pesquisa 51 trabalhadores manifestaram interesse em participar. Dos 51 trabalhadores, foram recrutados 31 voluntários, do sexo masculino, hígidos, com idade entre 20 e 50 anos, que não tivessem reconhecidamente doença cardiopulmonar e nem fizessem uso de medicamentos para hipertensão arterial, arritmia cardíaca, hipercolesterolemia e de anticoagulantes e que fossem, preferivelmente, não fumantes ou ex-fumantes, que fumaram menos do que 20 anos/maço e pararam de fumar há um ano ou mais. Os 31 participantes foram aqueles que tinham disponibilidade de se deslocar de sua cidade de origem á São Paulo, com permanência de 5-6 dias para realização dos exames.

Para melhor avaliar possível efeito genotóxico associado à exposição a poluentes da queima da cana, foi constituído um grupo controle formado 
por 17 indivíduos da mesma faixa etária, sendo 5 fumantes, residentes na cidade de Tatuí, localizada na mesma região e que nunca trabalharam no corte de cana. O recrutamento destes indivíduos foi feito através de aviso colocado em Serviço Público Municipal da cidade.

\subsection{Desenho do estudo}

Trata-se de um estudo observacional, prospectivo, com medidas repetidas, com os participantes avaliados em dois períodos: durante o período da safra (maio a novembro), quando ocorre o corte de cana-deaçúcar queimada e após o término da safra (período da entressafra: dezembro a abril), quando trabalharam em outras atividades não relacionadas ao corte de cana queimada.

Neste estudo, durante o período da safra, as avaliações dos trabalhadores foram realizadas nos meses de outubro e novembro de 2007 e durante o período da entressafra, nos meses de março e abril de 2008.

\subsection{Avaliação das condições de trabalho}

Foram realizadas visitas aos canaviais, no período da safra, nos meses de setembro a novembro de 2007, para conhecimento das atividades laborais realizadas pelos cortadores de cana. As observações foram principalmente quanto ao ritmo, intensidade de trabalho, movimentos 
realizados, organização do trabalho e condições ambientais detalhadas a seguir.

O mesmo procedimento foi repetido no período da entressafra, em abril de 2008, para o grupo de trabalhadores que esteve ligado a atividade do setor no período.

\subsection{Caracterização da exposição a material particulado (MP), temperatura e da umidade do ar}

Realizada com objetivo de caracterizar o nível de exposição a material particulado, principalmente presente durante o corte de cana, bem como caracterizar as condições climáticas.

Durante o mês de novembro de 2007 , no período da safra, foi realizada medida da concentração de material particulado $\left(\mathrm{MP}_{2,5}\right)$, da temperatura e umidade relativa do ar, tanto no canavial, como na zona urbana das cidades de Cerquilho (sede da usina) e Tatuí (onde reside a maioria dos cortadores). O procedimento foi repetido no período da entressafra, em abril de 2008.

Para a realização das medições foi estudado um ciclo da atividade que correspondeu ao mais representativo possível da atividade laboral habitual do trabalhador. Considerando que o trabalho é realizado de forma contínua e com pouca variação sobre a forma como é realizado, optamos por realizar amostragens de material particulado e variáveis climáticas em 3 períodos de 4 horas em três dias consecutivos. No período da entressafra, 
foram realizadas medições nas atividades de corte de cana crua (sem queima) e carpição, nas quais estavam envolvidos $60 \%$ dos trabalhadores que haviam trabalhado durante a safra. Os demais trabalhadores, $40 \%$, estavam empregados em atividades diversas e dispersas, relativas ao ramo da construção civil e serviços, não relacionadas á cultura de cana de açúcar, motivo pelo qual não foi possível realizar as medições nos seus locais de trabalho.

A amostragem e determinação de $\mathrm{MP}_{2,5}$ foi realizada com o uso de equipamento DustTraK ${ }^{\mathrm{TM}}$ Aerosol Monitor, marca TSI, modelo 8520 da TSI, com vazão de fluxo de 1,7 litros/minuto. Este equipamento realiza medição contínua das concentrações de material particulado, através de fotometria por feixe de luz a laser (Figura 2).

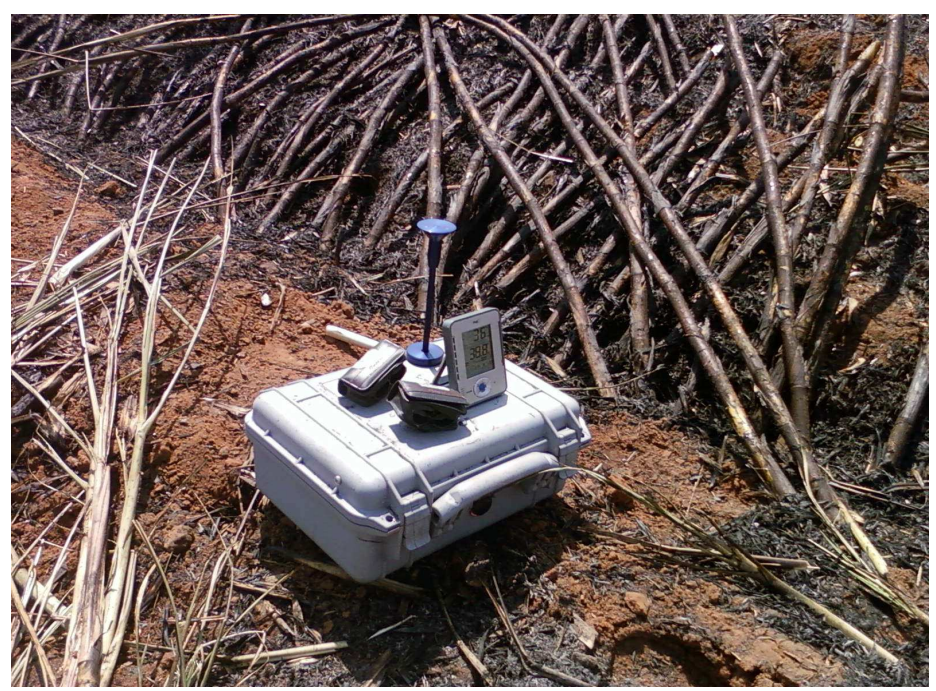

Figura 2- Monitor de material particulado MP2,5 (DustTrak) e Termohigrômetro

Foram instalados no equipamento seletores de $\mathrm{MP}_{2,5}$, sendo os resultados, expressos em $\mu \mathrm{g} / \mathrm{m}^{3}$, transmitidos para computador. No canavial, os monitores foram instalados nas áreas próximas onde a atividade estava 
sendo realizada (corte de cana queimada, corte de cana crua ou carpição). A queima do canavial varia de localização ao longo da safra, desde locais mais próximos á cidade, até dezenas de quilômetros.

A avaliação de temperatura e umidade foi realizada com Estação Termo-Higrômetro, Datalooger marca TFA (Figura 2) que permite coletar dados de temperatura e umidade relativa do ar de cinco em cinco minutos, e possui integração com interface para computador. O aparelho foi colocado próximo à área de trabalho, ao lado do equipamento de avaliação de material particulado, nos mesmos períodos de avaliação.

As medidas climáticas foram complementadas com dados de Estação automatizada localizada na região ${ }^{72}$.

\subsection{Avaliação do índice de Sobrecarga Térmica}

A avaliação da sobrecarga térmica foi realizada apenas no período da safra, pois este indicador tem como objetivo avaliar a sobrecarga no período mais desfavorável do ciclo de trabalho, que ocorre na safra, pois apesar das temperaturas ambientais apresentarem pouca diferença (temperaturas médias $22,2^{0} \mathrm{C}$ e $21^{\circ} \mathrm{C}$, em novembro de 2007 e abril de 2008 , respectivamente) ${ }^{72} \mathrm{o}$ ritmo de trabalho é muito mais intenso durante a safra.

As medidas foram realizadas conforme preconizado pela legislação brasileira (Norma Regulamentadora 15 -NR15- Portaria 3214/78 do Ministério do Trabalho e Emprego $)^{73}$ e normas internacionais ${ }^{18}$, através de cálculo do 
IBUTG (Índice de Bulbo Úmido Termômetro de Globo), indicador utilizado para avaliação de exposição ocupacional ao calor e sobrecarga térmica.

Utilizou-se equipamento eletrônico "Medidor de Stress Térmico", modelo 500 da marca Quest Temp ${ }^{\circ}$ 30, devidamente cal ibrado e que realiza calculo direto de IBUTG (Figura 3).

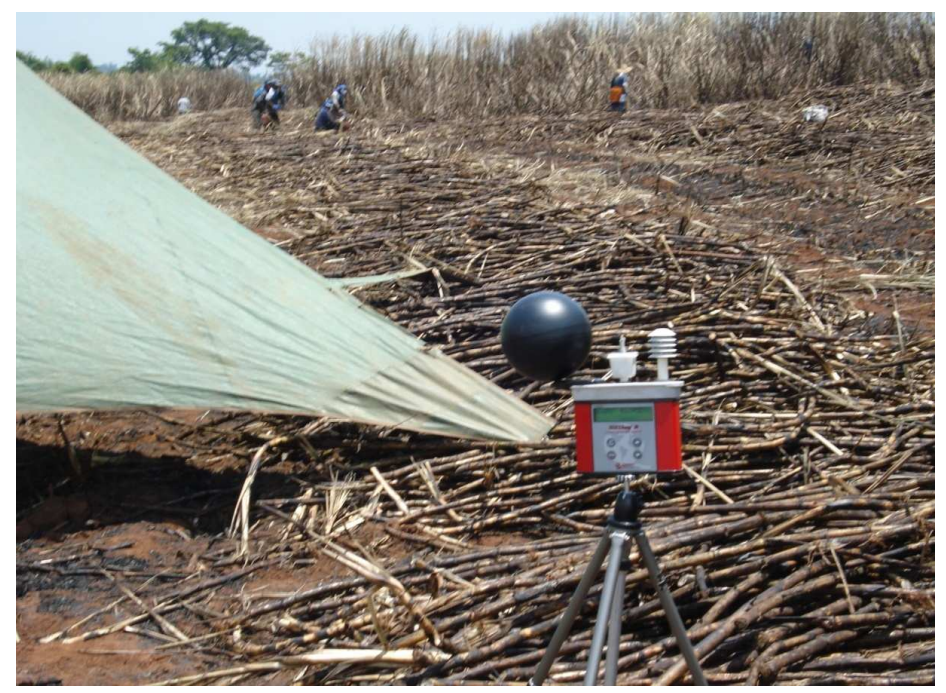

Figura 3- Medidor de Stress Térmico

Este equipamento é constituído de:

Termômetro de Globo (Tg) composto por uma esfera oca de cobre, pintada externamente de preto fosco, um termômetro de mercúrio com escala de $+10^{\circ} \mathrm{C}$ a $+150^{\circ} \mathrm{C}$ e precisão mínima de leitura de $\pm 0,1^{\circ} \mathrm{C}$;

Termômetro de Bulbo Úmido Natural (Tbn) composto de um termômetro de mercúrio com escala de $+10^{\circ} \mathrm{C} \mathrm{a}+50^{\circ} \mathrm{C}$ e precisão mínima de leitura de $\pm 0,1^{\circ} \mathrm{C}$, um Erlenmeyer de $125 \mathrm{ml}$, contendo água destilada, pavio de algodão com alto poder de absorção de água e um tripé do tipo telescópico; 
Termômetro de Bulbo Seco (Tbs), composto de um termômetro de mercúrio com escala de $+10^{\circ} \mathrm{C}$ a $+50^{\circ} \mathrm{C}$ e precisão mínima de leitura de $\pm 0,1^{\circ} \mathrm{C}$. O cálculo do IBUTG é dado pela fórmula: IBUTG $=0,7 \mathrm{Tbn}+0,2 \mathrm{Tg}+0,1 \mathrm{Tbs}$.

A medição foi realizada durante uma jornada de trabalho, 08:10 as 15:10 horas, sendo determinado a média a cada 60 minutos. Foi também feito uma análise exploratória de um ciclo de uma hora, em situação desfavorável, levando em conta todos os parâmetros necessários para tal medição.

\subsection{Procedimentos observados para avaliação individual}

Os trabalhadores foram avaliados no Instituto do Coração do Hospital das Clínicas de São Paulo (InCor/HCFMUSP). Para isto eram trazidos de suas cidades, aos sábados até São Paulo, onde permaneciam durante 6 dias, comparecendo diariamente ao InCor/HC para realização dos exames programados, descritos a seguir. As avaliações foram realizadas de modo seqüencial de forma a evitar possíveis influencias entre os exames, por exemplo, a ergoespirometria foi realizada em dia subseqüente a pletismografia de oclusão venosa e teste de atividade simpática (Figura 4). 
Cronograma de Avaliações

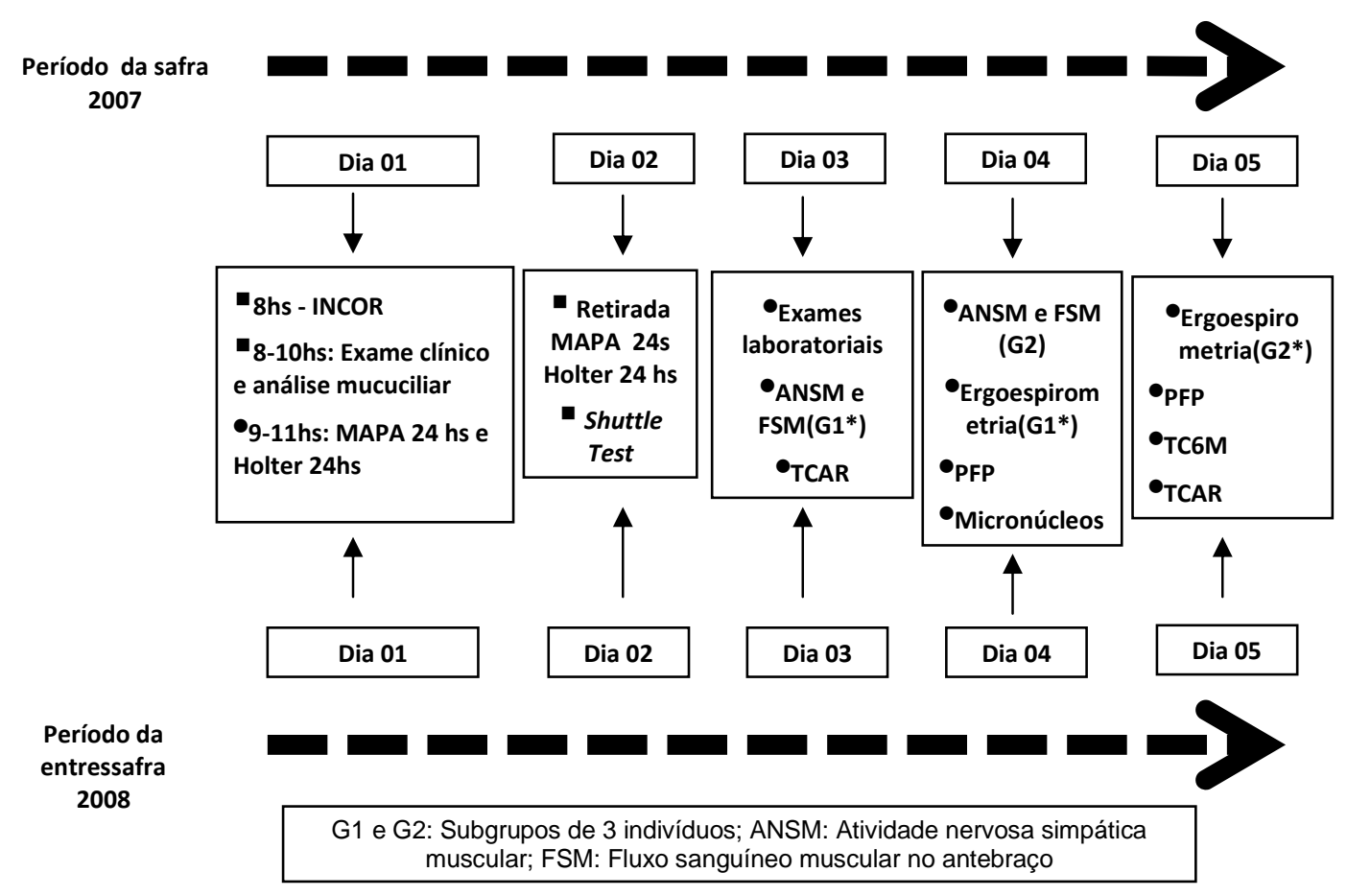

Figura 4- Sequência de avaliações: 5 grupos de 6 trabalhadores, cada

\subsection{Exames realizados}

Mediante consentimento pós-esclarecido individual, trinta e um trabalhadores foram avaliados no período da safra de cana de cana de 2007, e destes, vinte e oito foram reavaliados no período da entressafra, quando estavam envolvidos em atividades que não o corte de cana queimada.

\subsubsection{Exame Clínico}

Realizado por médicos clínico e pneumologista. Durante o exame clínico foi aplicado um questionário desenvolvido para o estudo abordando 
informações gerais sobre o processo de trabalho, histórico ocupacional, anamnese clínica, tabagismo, antecedentes mórbidos pessoais e familiares e a presença de sinais e sintomas gerais e respiratórias na $1^{1 \underline{a}}$ avaliação durante o período da safra (Anexo A) e na $2^{\underline{a}}$ avaliação - durante o período da entressafra (Anexo B). Após o questionário os indivíduos eram submetidos a exame clínico. A medida instantânea da pressão arterial considerada foi a realizada no quinto dia da estadia dos cortadores no hospital. Após 5 minutos de repouso, foram realizadas 3 medidas com intervalo de 1 minuto e feita a média das duas últimas medidas, conforme recomendação da V Diretrizes Brasileira de Hipertensão Arterial $^{74}$.

\subsubsection{Exames complementares}

\subsubsection{Exames Laboratoriais gerais}

Os exames laboratoriais, a seguir relacionados, foram realizados no Laboratório de Análises Clínicas do InCor-HCFMUSP:

- Hemograma completo com contagem de plaquetas, através de contagem automatizada por equipamento Coulter, modelo STKS

- Proteína C Reativa (PCR) de alta sensibilidade, dosada por ensaio imunológico (imunonefelometria), com emprego de reagente de alta sensibilidade, equipamento BNII da Siemens

- Fibrinogênio, dosado pelo método de Clauss 
- Colesterol total e frações, dosados em equipamento automatizado Dimension RXL da Siemens, por Fotometria de Absorção

- Triglicérides, dosados em equipamento automatizado Dimension RXL da Siemens, por Fotometria de Absorção

- Glicemia de jejum dosada em equipamento automatizado Dimension RXL da Siemens, por Fotometria de Absorção

- Dímero D: dosado em amostra de sangue, através de imunoturbidimetria, equipamento Trinity Biotech, modelo Amax 190

- Proteínas totais e albumina em equipamento Dimension $R X L$ da Siemens, por Fotometria de absorção

- Creatina fosfoquinase (CPK), Aspartato amino transaminase (AST), Alanina amino transferase (ALT), Desidrogenase Lática (DHL), em equipamento Dimension $R X L$ da Siemens, por Fotometria de Absorção

- Ácido úrico, método enzimático colorimétrico automatizado, com emprego de equipamento Dimension RXL da Siemens, por Fotometria de Absorção

- Sódio, Potássio, Cálcio Fósforo, determinados em equipamento Dimension RXL da Siemens. Para dosagem de sódio e potássio foi utilizada a técnica ISE (Eletrodo Íon Seletivo) e para dosagem de cálcio e fósforo foi utilizado a técnica de Fotometria de Absorção

- Coagulograma, realizado através de método turbidimétrico automatizado, em equipamento Trinity Biotech, modelo Amax 190 
- Homocisteína plasmática, dosada por imunoensaio por quimioluminescência automatizada

\subsubsection{Atividade de enzimas antioxidantes}

A dosagem das enzimas antioxidantes foi feita no Laboratório do Departamento de Farmácia da Universidade de São Paulo (FFUSP).

A determinação da atividade da enzima Glutationa Peroxidase (GPx), foi feita através do método descrito por Flohé \& Günzle ${ }^{75}$. Utilizou-se como substrato o Tertibutihidroperoxidase e a formação de glutationa oxidase (GSSG) foi indiretamente monitorado por espectrofotômetro, através de consumo de NAPDH a 340 nm (Power wave 340, Bio-Tek Instrumento INC, softaware Kc4 v3.0), durante 3 minutos.

A atividade da enzima Glutationa Redutase (GR), foi realizada de acordo com Calberg \& Mannervik ${ }^{76}$. A redução do GSSG para GSH foi medida pelo consumo de NADPH e monitorado PR espectrofotômetro a $37^{\circ} \mathrm{C}$ por 20 minutos a $340 \mathrm{~nm}$ (Power wave 340, Bio-Tek Instrumento INC, softaware Kc4 v3.0). O balanço entre atividade da GPX e GR é crucial para manter o nível de GSH.

A atividade da enzima Glutationa transferase (GST) foi avaliada através da medição da conjugação do 1-cloro-2,4-dinitrobenzeno (CDNB). A formação do complexo foi monitorado a $25^{\circ} \mathrm{C}$, a $340 \mathrm{~nm}$, em um espectrofotômetro Power wave 340, Bio-Tek Instrumento INC, softaware Kc4 v3.0). 
Todos os ensaios enzimáticos foram corrigidos para o teor de hemoglobina e expressa como Ulg de hemoglobina. Todas as avaliações foram conduzidas em triplicata.

\subsubsection{Avaliação da peroxidação lipídica}

Foi feito através da quantificação do Malondialdeído (MDA) plasmático pela reação com o ácido tiobarbitúrico a $90^{\circ} \mathrm{C}$ por uma hora, de acordo com Sim, $2003^{77}$. Após a centrifugação para remoção de proteína, o sobrenadante foi filtrado através de uma membrana 0.2 um e o complexo colorido foi analisado pelo método de cromatografia líquida de alta eficiência (HPLC), usando uma coluna analítica C-18 (Phenomenex150 mm x 4,6, 10 um), eluída com $50 \mathrm{~nm}$ tampão fosfato (ph 7.0): metanol (65:35 vlv) a 1 mm\min e detectado por espectofotômetro a 532nm. MDA foi expresso por nmol de MDAlmg de proteína. O conteúdo de proteína e hemoglobina foram determinados por reagentes Bradford Doly, método empregado em outros estudos $^{78}$.

\subsubsection{Prova de Função Pulmonar e Teste de Broncoprovocação}

Todos os indivíduos foram avaliados no período matutino, sem consumo de café, chás, refrigerantes e bebida alcoólica.

As avaliações da função pulmonar, descritas a seguir, foram realizadas no pletismógrafo ELITE (Medgraphics ELITE Series 
Plethysmograph, Medical Graphics Corporation, St. Paul, Mn, USA), com os exames realizados de acordo com as recomendações ATS/ERS $2005^{79,80}$.

Espirometria: Foram obtidos volume expiratório forçado no primeiro segundo (VEF1), capacidade vital forçada (CVF), Relação VEF1/CVF, fluxo expiratório forçado de $25 \%$ a $75 \%$ da expiração $\left(\mathrm{FEF}_{25-75}\right)$, capacidade vital lenta (CVL) e capacidade inspiratória (Cl).

Pletismografia - Com uso de pletismografia de corpo inteiro foram avaliadas a resistência (Raw) e condutância (Sgaw) das vias aéreas, o volume de gás torácico na capacidade residual funcional (CRF), a capacidade pulmonar total (CPT) e o volume residual (VR).

Medida da capacidade difusiva (DLCO) - Foi mensurada a capacidade difusiva através da técnica de respiração única com monóxido de carbono.

No presente estudo, foram empregados para cálculo do preditos de normalidade:

a) Para espirometria: Pereira $(2007)^{81}$, b) para Volumes Pulmonares e Difusão de Monóxido de Carbono: Neder $(1999)^{82}$, c) para cálculo da resistência e condutância (Rawlsgaw): DuBois $(1954)^{83}$.

Teste de Broncoprovocação (TBP): $O$ agente de escolha foi a metacolina, sob a forma de pó seco. O diluente foi solução salina normal, conforme protocolo da ATS (American Thoracic Society) ${ }^{84}$. A concentração do primeiro aerossol foi de $0,03 \mathrm{mg} / \mathrm{ml}$. As doses subseqüentes foram 0 dobro da dose anterior correspondendo a 0,$06 ; 0,125 ; 0,250 ; 0,50 ; 1,00$; 2,00; 4,00; 8,00 e $16 \mathrm{mg} \backslash \mathrm{ml}$. Após cada dose o $\mathrm{VEF}_{1}$ foi medido. Os passos 
foram repetidos até que o $\mathrm{VEF}_{1}$ diminuisse $20 \%$ ou chegasse a menos do que 1,5 L ou até que a concentração mais alta tenha sido administrada. Em caso do $\mathrm{VEF}_{1}$ diminuir $20 \%$ (teste positivo) o teste foi interrompido e administrado $200 \mathrm{mcg}$ de salbutamol por spray oral. O indivíduo só deixou o laboratório com recuperação funcional $\left(\mathrm{VEF}_{1}\right.$ com pelo menos $90 \%$ do basal).

\subsubsection{Teste de caminhada de 6 minutos (TC6M)}

O paciente foi instruído a caminhar num corredor de 30 metros demarcados por dois cones, na máxima velocidade tolerada, durante seis minutos. Os incentivos verbais foram padronizados e realizados a cada minuto, respeitando as orientações da $A T S^{85}$. O paciente pôde reduzir a velocidade ou realizar pequenas pausas, sempre que julgasse necessário. Neste caso, o examinador avisou a retornar ao teste logo que se sentisse capaz. Foram registradas a saturação arterial de oxigênio e a freqüência cardíaca, a freqüência respiratória, a distância percorrida e a escala de Borg $^{86}$, no início e ao final da caminhada. Para os registros da oximetria e do pulso arterial foi utilizado oxímetro digital de pulso, Modelo Onyx 9500 da NONIN Medical, InC. 


\subsubsection{Monitoramento da pressão arterial por 24 hs (MAPA 24 horas)}

Todos os trabalhadores foram submetidos à medida de pressão arterial por 24 horas (MAPA). As medidas foram feitas em intervalos de 10 minutos no período diurno (5:00hs as $22: 00 \mathrm{hs})$ e de 20 minutos no período noturno (das 22 hs às 5:00hs) com uso de manguito com $24 \mathrm{~cm} \times 32 \mathrm{~cm}$. Foram registradas em gravador Spacelabs Medical, modelo 90207, acoplado à cintura do indivíduo.

Após 24hs os dados registrados foram transferidos para computador, onde foram guardados para análise ao final da coleta dos dados. Cada indivíduo recebeu um diário para registro de intercorrências durante os registros. A realização do MAPA seguiu os critérios preconizados pela IV Diretrizes Brasileiras de Monitorização Ambulatorial da Pressão Arterial ${ }^{87}$.

\subsubsection{Monitoramento do ECG por 24 horas (Holter 24 horas) com medida da variabilidade da frequência cardíaca}

Os participantes foram submetidos a monitoramento eletrocardiográfico ambulatorial por 24 horas, com uso de gravadores portáteis digitais Seer Ligth 24 hs da GE, aos quais foram acoplados eletrodos revestidos com cloreto de prata nas posições V1 a V6 do tórax. Cada examinado recebeu um diário para registro de atividades e intercorrências. O registro contínuo foi transferido para computador dotado de software para análises da variabilidade da freqüência cardíaca no 
domínio do tempo (desvio padrão dos intervalos RR normal - SDNN, desvio padrão das médias dos intervalos RR normal - SDANN, raiz quadrada da média da diferença entre os intervalos NN adjacentes - RMSSD) e da freqüência (Baixa freqüência - LF, alta frequência $H F$, muito baixa freqüência - VLF e razão baixa e alta freqüência- $L / H)$, conforme recomendado pela Task Force of European Society of Cardiology and North American Society of Pacing and Eletrophysiology ${ }^{88}$, metodologia utilizada em trabalho do nosso grupo $^{52}$.

\subsubsection{Teste de caminhada Shuttle Incremental (TCSI)}

O paciente foi estimulado, através de um estímulo sonoro padronizado, a caminhar em um corredor de dez metros, demarcados por dois cones. Por equívoco ocorrido na $1^{\text {a }}$ fase das avaliações a velocidade inicial foi de $1,00 \mathrm{~m} / \mathrm{s}$, ou seja, o dobro do preconizado ${ }^{89}$ e, a cada minuto transcorrido, incrementou-se em 0,34 m/s, e não 0,17m/s (Quadro 1) através do mesmo estímulo sonoro (menor intervalo entre os bips). Para permitir comparação na $2^{\text {a }}$ fase, período da entressafra, foi empregado o mesmo protocolo, ou seja, a velocidade inicial também foi de 1,0 m/s.

Além de a velocidade inicial ter sido maior $(1,0 \mathrm{~m} / \mathrm{s}$ ao invés de $0,5 \mathrm{~m} / \mathrm{s})$ o incremento de velocidade foi também o dobro do preconizado para cada mudança de estágio $(0,34 \mathrm{~m} / \mathrm{s}$ ao invés de $0,17 \mathrm{~m} / \mathrm{s})$. 
Quadro 1 - Os 12 níveis de velocidade do Shuttle Test e os 12 níveis de velocidades utilizadas

\begin{tabular}{|ccc|}
\hline Níveis & Velocidade $(\mathbf{m} / \mathbf{s})$ & Velocidades utilizadas $(\mathbf{m} / \mathbf{s})$ \\
\hline 1 & 0,50 & 1,00 \\
2 & 0,67 & 1,34 \\
3 & 0,84 & 1,68 \\
4 & 1,01 & 2,02 \\
5 & 1,18 & 2,36 \\
6 & 1,35 & 2,70 \\
7 & 1,52 & 3,04 \\
8 & 1,69 & 3,38 \\
9 & 1,86 & 3,72 \\
10 & 2,03 & 4,06 \\
11 & 2,20 & 4,40 \\
12 & 2,37 & 4,74 \\
\hline \hline
\end{tabular}

Cada minuto corresponde a um nível, e cada transição de nível foi sinalizada por um estímulo auditivo (bip triplo). Tal incremento de esforço foi mantido até a exaustão do paciente, sendo finalizado quando o indivíduo não conseguiu mais acompanhar a velocidade do teste ou decidiu parar.

Antes e no final da caminhada foi mensurada a pressão arterial sistêmica e questionado o grau de fadiga geral e em membros inferiores (escala de Borg modificada) ${ }^{86}$. Os testes de esforços foram realizados no início da manhã entre a $22^{\mathrm{a}}$ e a $24^{\mathrm{a}}$ hora dos registros do MAPA e Holter e foram acompanhados por um médico e um fisioterapeuta responsáveis pelo estudo. 


\subsubsection{Teste do exercício cardiorrespiratório}

Todos os indivíduos foram avaliados, nas duas fases, no período vespertino, sem consumo de café, chás, refrigerantes e bebida alcoólica.

Realizado o teste incremental até o limite da tolerância em cicloergômetro de frenagem eletromagnética, com determinação respiraçãopor-respiração, de variáveis metabólicas, ventilatórias e cardiovasculares, em equipamento Medgraphics cardio2: medical Graphics Corporation ST Paul Mn, USA. Após um período inicial de repouso de 2 minutos e de exercício sem carga de 2 minutos, a carga foi aumentada, em rampa, 20 watts por minuto. O limite de tolerância foi determinado pelo paciente ao atingir o esforço que considerar máximo, pelo técnico ao perceber incapacidade do paciente em manter o esforço ou quando evidenciado critério para interrupção do exame de acordo com o consenso internacional da $\operatorname{ATS}^{90}$.

Para análise da resposta da freqüência cardíaca e da pressão arterial ao exercício foi utilizado o critério sugerido pela II Diretrizes da Sociedade Brasileira de Cardiologia Sobre Teste Ergométrico de $2002^{91}$. Consideramos como retardo na redução da FC, quando após 1 minuto da recuperação a FC não reduziu 12 bpm ou mais, em relação a valor do pico máximo.

Já em relação a pressão arterial (PA), segundo este consenso, considera-se hipertensão reativa ao exercício valores de pressão arterial sistólica (PAS) acima de 220 mmHg elou elevação de 15 mmHg ou mais da 
pressão diastólica (PAD), partindo-se de valores normais de pressão de repouso ( $P A S \geq 140 \mathrm{mmGh}$ e $P A D \geq 90 \mathrm{mmHg}$ ).

\subsubsection{Avaliação da atividade nervosa simpática muscular (ANSM)}

A ANSM foi avaliada através da técnica direta de registro de multiunidade da via pós-gangliônica eferente, do fascículo nervoso muscular, na parte posterior do nervo fibular, imediatamente inferior à cabeça fibular $\left(\right.$ Figura 5) ${ }^{92}$.

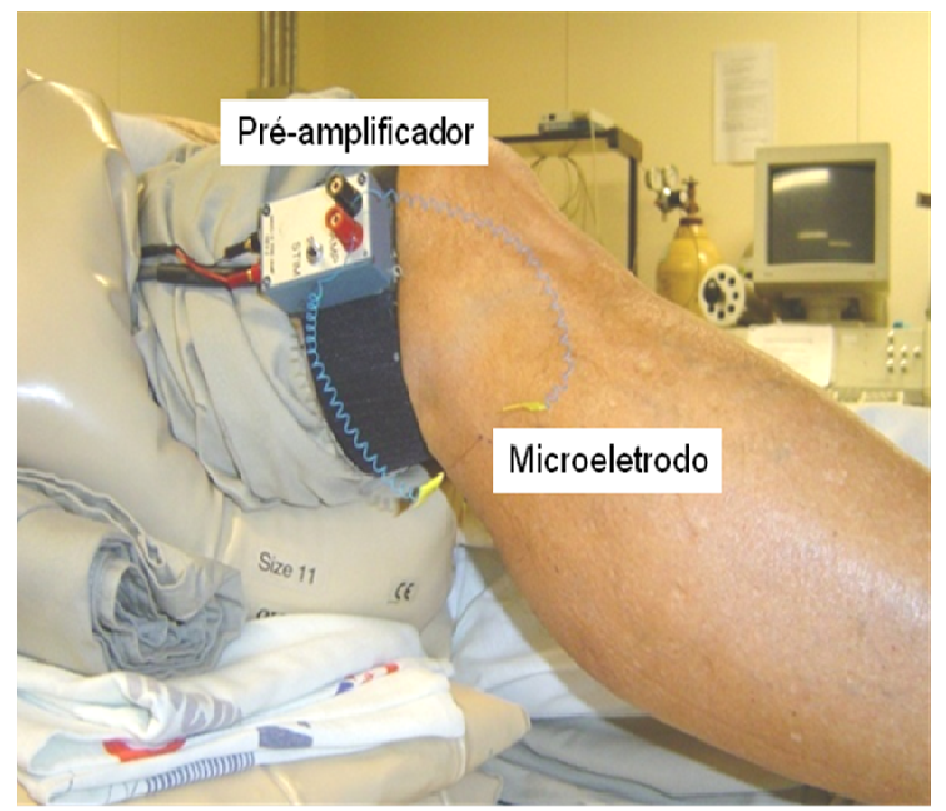

Figura 5- Cortador durante o exame de Microneurografia

Os registros foram obtidos por meio de implante de um microeletrodo no nervo fibular e de um microeletrodo referência, na pele, a aproximadamente $1 \mathrm{~cm}$ de distância do primeiro. Os eletrodos foram conectados a um pré-amplificador e o sinal do nervo foi alimentado através de um filtro passabanda sendo, em seguida, dirigido a um discriminador de 
amplitude com saída em caixa de som. Para fins de registro e análise, o neurograma filtrado foi alimentado por um integrador de capacitânciaresistência para a obtenção da voltagem média da atividade neural.

A atividade nervosa simpática foi avaliada utilizando-se um registro da atividade nervosa simpática neuromuscular em um polígrafo (Gold) numa velocidade de $5 \mathrm{~mm} / \mathrm{s}$. O sinal do nervo foi analisado por meio da contagem do número de descargas ocorridas em cada minuto.

\subsubsection{Avaliação do fluxo sangüíneo muscular}

O fluxo sangüíneo muscular foi avaliado pela técnica de pletismografia de oclusão venosa (Figura 6$)^{92}$. O braço contralateral não-dominante foi elevado acima do nível do coração para garantir uma adequada drenagem venosa. Um tubo silástico preenchido com mercúrio, conectado a um transdutor de baixa pressão e a um pletismógrafo, foi colocado ao redor do antebraço, a $5 \mathrm{~cm}$ de distância da articulação úmero-radial, e conectado a um pletismógrafo. Um manguito do punho foi inflado a um nível suprasistólico, 1 minuto antes do início das medidas. Em intervalos de 10 segundos, o manguito do braço foi inflado acima da pressão venosa por período de 10 segundos. $\mathrm{O}$ aumento em tensão no tubo silástico refletiu 0 aumento de volume do antebraço e, consequentemente, sua vasodilatação. 


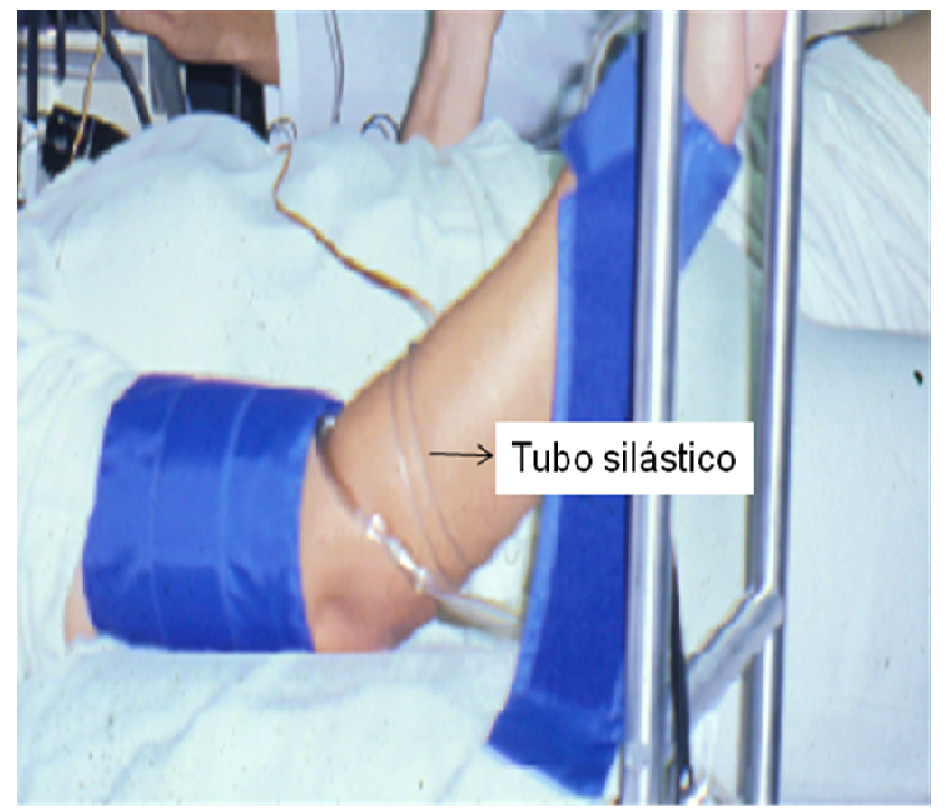

Figura 6- Cortador durante o exame de Plestimografia de Oclusão Venosa em antebraço

O sinal de fluxo foi gravado em computador numa freqüência de $500 \mathrm{~Hz}$ e, em seguida, analisado no programa Windaq. A condutância vascular do antebraço foi calculada pela divisão do fluxo sangüíneo muscular no antebraço ( $\mathrm{ml}$ de sangue/min/100ml de tecido) pela pressão arterial média (mmHg), multiplicado por 100, e expressa em unidades.

A microneurografia e a pletismografia de oclusão venosa foram realizadas pela manhã, nos dois períodos (safra e entressafra), estando devidamente alimentados, sem consumo de café, chás, refrigerantes e bebida alcoólica. Os pacientes não foram submetidos a procedimento com esforço físico ou stress 24 horas antes do exame e nas 24 horas seguintes.

Na realização destes procedimentos, foram feitos registro de pressão arterial e freqüência cardíaca $(F C)$, durante período basal e no período de exercício, conforme descrito a seguir: 
Avaliação da pressão arterial: Durante o protocolo em repouso a pressão arterial foi medida continuamente, a cada batimento cardíaco, por técnica não-invasiva. Um manguito de tamanho adequado em torno do dedo médio da mão direita foi colocado, mantendo-se o braço direito apoiado sobre uma mesa de altura ajustável de modo que o dedo fique na altura do ventrículo esquerdo. Esse manguito foi conectado a um monitor de pressão arterial (Ohmeda, 2300 Finapress), o qual aferiu a pressão arterial sistólica, diastólica e média a cada batimento cardíaco. Esse sinal foi gravado em um computador numa freqüência de $500 \mathrm{~Hz}$ e, em seguida, analisado no programa Windaq.

Durante o protocolo de exercício isométrico, a pressão arterial foi aferida a cada minuto, no membro inferior esquerdo, pelo método oscilométrico (monitor automático de pressão arterial - Dixtal, modelo DX 2710).

Avaliação da freqüência cardíaca: A freqüência cardíaca foi obtida por meio do registro eletrocardiográfico. O sinal do eletrocardiograma foi gravado em computador numa freqüência de $500 \mathrm{~Hz}$ e, em seguida, analisado no programa Windaq.

\section{- Protocolo Experimental 1 - Registro basal}

A atividade nervosa simpática muscular, o fluxo sangüíneo periférico, a pressão arterial e a freqüência cardíaca, foram registrados por um período de 10 minutos basais, com o paciente deitado, em repouso. 


\section{- Protocolo Experimental 2 - Exercício isométrico}

A resposta da atividade nervosa simpática muscular, do fluxo sangüíneo periférico, da pressão arterial e da freqüência cardíaca, durante o exercício isométrico foi realizado da seguinte maneira: 3 minutos de basal, 3 minutos de exercício de preensão de mãos em 30\% da contração voluntária máxima, seguidos de 3 minutos de recuperação.

\subsubsection{Tomografia computadorizada de tórax de alta resolução}

Tomografia Computadorizada de Alta Resolução (TCAR) de tórax foi realizada em aparelho multislice da Toshiba Aquilion 64, com cortes de 1 mm, com janelas para pulmão -800/1200 UH em inspiração e expiração e janela para mediastino $40 / 355 \mathrm{UH}^{93}$.

A leitura foi realizada por dois radiologistas, com bastante experiência em leitura de imagens radiológicas pulmonares. Nos casos discordantes um terceiro leitor fazia a leitura. Foi calculado o índice de Kappa, para análise de observação inter-leitor ${ }^{94}$. A leitura foi feita para análise de mediastino (linfonodos calcificados), pleura (placas pleurais) e parênquima (micronódulos, espessamento pleural e aprisionamento aéreo).

As leituras foram feitas nos dois períodos, porém como não houve muita variação intra-leitores nas duas fases, optou-se por utilizar a primeira leitura dos 31 trabalhadores. 


\subsubsection{Teste da Sacarina - Avaliação do tempo de transporte mucociliar (TMC)}

Para a realização do teste da sacarina, o paciente foi orientado a se sentar em uma cadeira com encosto e olhar para o horizonte, conforme protocolo padronizado ${ }^{95}$. Foi solicitado que o paciente faça uma leve extensão cervical. Em seguida, foi depositada uma pequena quantidade de sacarina, introduzida delicadamente e posicionada na superfície da borda inferior do corneto médio da narina (direita ou narina de fluxo aéreo livre), através de um canudo plástico de até $2 \mathrm{~mm}$ de diâmetro e $5 \mathrm{~cm}$ de comprimento. Logo a seguir foi solicitado ao paciente que reposicione sua cabeça. O paciente foi instruído a relatar o momento em que sentisse 0 gosto da sacarina. O tempo de TMC foi observado através de um cronômetro. O cronômetro era acionado assim que o paciente estivesse com a sacarina introduzida e a cabeça reposicionada, com o olhar direcionado ao horizonte, e acionado novamente no momento em que o paciente relatava o gosto doce da sacarina na porção posterior faringe. Foi também recomendado ao paciente que ele mantivesse o padrão respiratório normal, evitando falar, tossir ou inspirar profunda ou rapidamente durante o procedimento. Caso o paciente não sentisse o gosto da sacarina após 1 hora, o procedimento era interrompido e um grânulo de sacarina era colocado na ponta da língua do paciente para assegurar que o mesmo é capaz de sentir o gosto da sacarina. Em caso do paciente ser sensível ao paladar doce, o procedimento seria repetido após 24 horas de interrupção. 


\subsubsection{Avaliação de efeitos genotóxicos decorrentes da exposição à material particulado}

Foi utilizado o método de contagem de micronúcleos em células da mucosa oral.

Este método consiste no esfoliamento de células epiteliais da mucosa oral com o auxílio de uma espátula de madeira, durante cinco minutos, por paciente ${ }^{96}$. O material coletado foi colocado em lâminas que foram secas à temperatura ambiente, fixadas em álcool 70 graus e coradas.

Posteriormente as amostras foram submetidas à contagem de micronúcleos em microscopia óptica, sob o aumento de 400X (análise de 500 células por lâmina).

O mesmo procedimento foi realizado no grupo controle.

\subsection{Análises estatísticas}

As variáveis categóricas são apresentadas como número absoluto e porcentagem e as variáveis contínuas como médias e desvio padrão ou mediana e intervalo interquartil, conforme a distribuição. Foi realizada análise descritiva das variáveis estudadas e os valores obtidos, nos períodos da safra e entressafra, comparados por testes estatísticos para medidas repetidas (teste T pareado ou Wilcoxon Rank test, conforme apropriado). $\mathrm{O}$ teste de McNemar foi utilizado para avaliar a diferença entre prevalências. 
Quando o nível de significância das diferenças das medidas entre os dois períodos avaliadas pelo test T pareado ou Wilcoxon Rank test, foi $\leq 0,10$ foram realizadas análise de regressão linear, pelo método de equações de estimativas generalizadas (GEE), com estimativa robusta do erro padrão, para avaliar os efeitos do trabalho na safra e de outras variáveis de efeito. Todos os modelos testados foram ajustados para idade, índice de massa corpórea (IMC), tempo de trabalho na safra, e tabagismo (não tabagismo como referência).

Foi assumida correlação interna igual para as medidas repetidas em cada indivíduo (exchangeable correlation). Para avaliar o efeito dos indicadores de VFC e da ANSM sobre a pressão arterial, essas variáveis foram acrescentadas aos modelos anteriores, controlando-se também para a safra (PA $\sim$ SDNN/ANSM + safra + idade + tabagismo + IMC + tempo de trabalho). As análises foram feitas com o programa S-Plus, versão 6.2 para windows e a função GEE foi obtida de StatLib (http://lib.stat.cmu.edu/). Foi adotado o nível de significância de 0,05.

O estudo foi aprovado pelo Comitê de Ética do Hospital das Clínicas da Faculdade de Medicina da Universidade de São Paulo e termo de consentimento foi obtido de todos os participantes (CAPPESQ nํ0854107). 


\section{RESULTADOS}

\subsection{Caracterização das condições de trabalho}

O período da safra em 2007 durou de maio a meados de dezembro. Como preparativo para o corte manual, a queima da cana era realizada na noite anterior, iniciando-se aproximadamente as 22:00 horas com duração de 3-5 horas, fazendo com que no início do corte, às 7:00 horas, diversas vezes, houvesse palha fumegante, uma das principais queixas dos trabalhadores.

A Figura 7 mostra o cortador de cana trabalhando no período da safra. Durante a observação do trabalho, verificou-se que os cortadores desferem vários golpes com o facão e realizam flexões do tronco para proceder ao corte neste período.
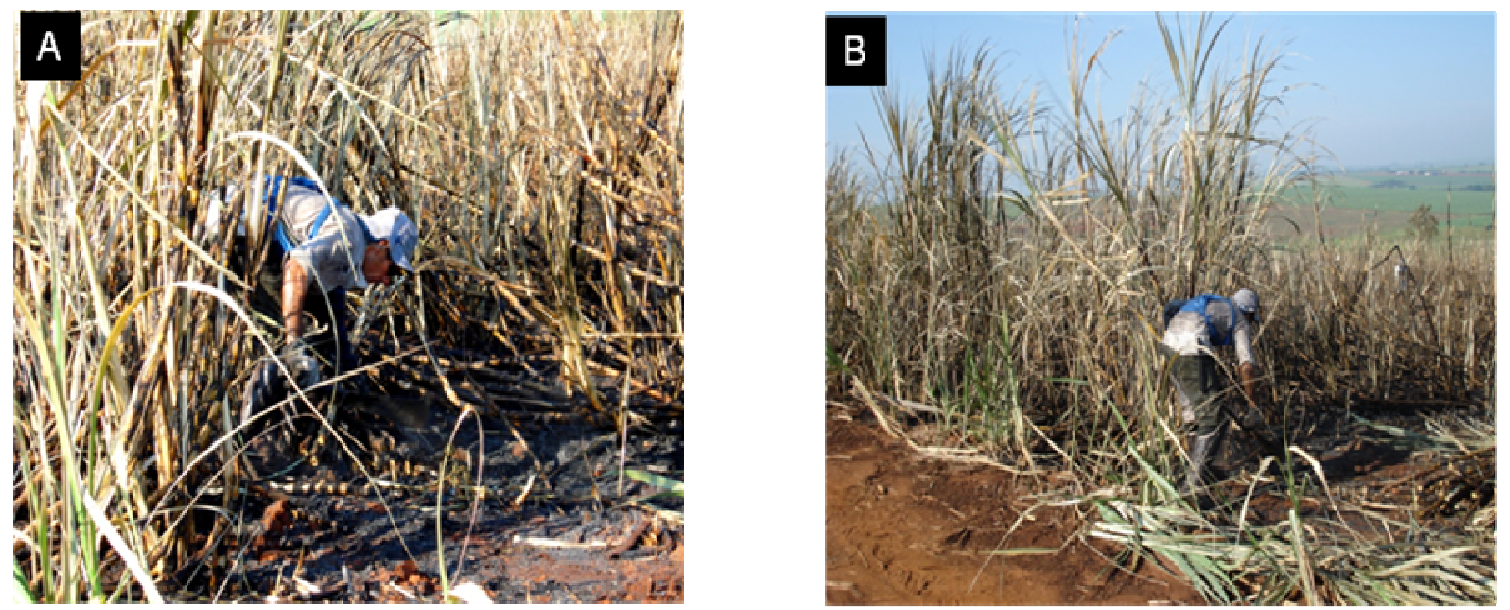

Figura 7- Cortadores trabalhando no corte de açúcar queimada, durante o período da safra 
Durante 0 corte as fácies e as roupas do trabalhador ficam impregnadas de material carbonáceo das palhas queimadas e pode-se visualizar a presença de material particulado em suspensão.

A jornada diária de trabalho é de $8: 20$ hs (7:00-15:20hs), com intervalo de 30 minutos para almoço, em regime 6/1 (uma folga a cada seis dias). As refeições são feitas sob tenda de lona. São fornecidos recipientes de 5 litros com água. Os cortadores referem consumir cerca de 5-10 litros de água por jornada e fazer uso de $200 \mathrm{ml}$ de solução de hidratação oral fornecida pela empresa. Referem cortar, entre 7 a 14 toneladas de cana por dia, com uma média de 11 toneladas por trabalhador. A variação depende do tipo da cana, do trabalhador e da época do corte. A maioria informou que no final da safra diminui a produtividade devido ao cansaço e ao calor.

No período da entressafra, a jornada de trabalho é das 7:00 as 17:00 horas, com 1 hora de almoço, cinco dias por semana. Dezoito trabalhadores $(64,29 \%)$ continuaram trabalhando na lavoura da cana-de-açúcar em atividades de carpir (Figura 8a), plantio e corte da cana crua usada para plantio (Figura $8 b)$, os demais trabalhadores $(35,71 \%)$ realizaram atividades diversas fora da usina (limpeza pública, pedreiro, serraria, agricultura). 

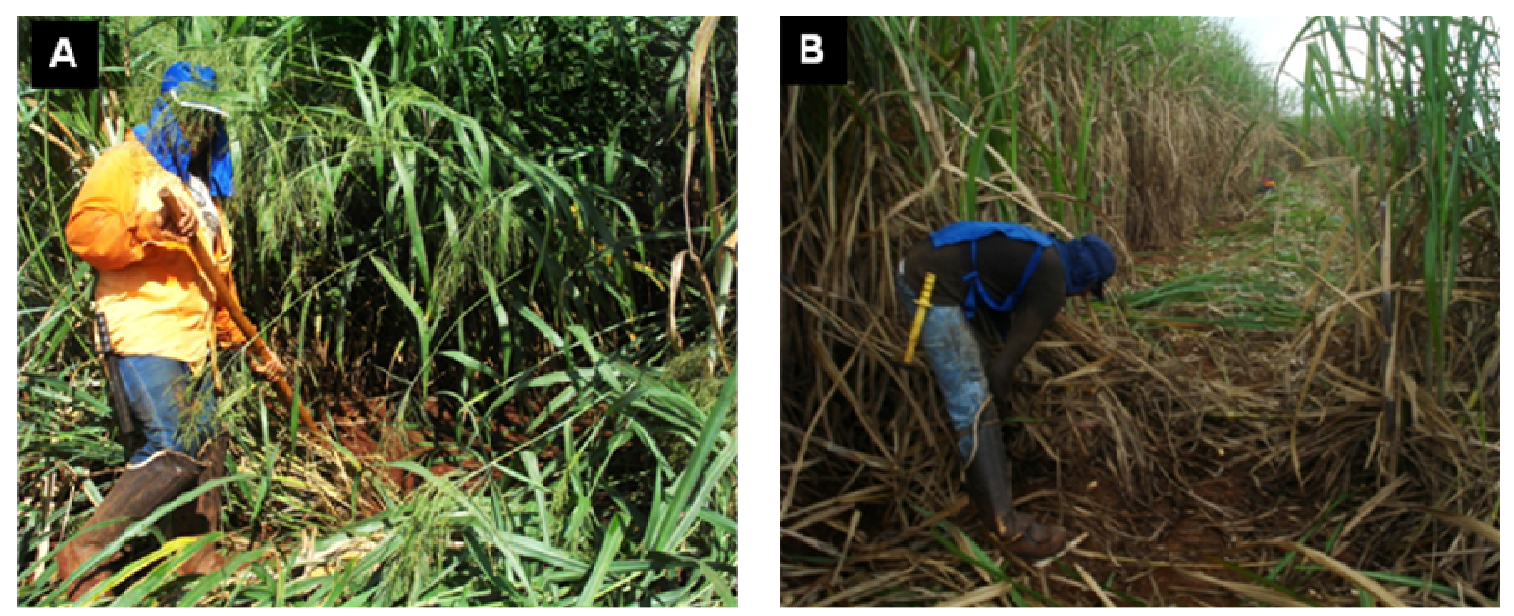

Figura 8- Cortadores no canavial durante o período da entressafra. A: Atividade de carpição; B: Atividade do corte de cana-de-açúcar crua, para uso no plantio

\subsection{Caracterização ambiental de material particulado, temperatura e umidade relativa do ar}

Durante os períodos medidos na safra, a concentração média de $\mathrm{MP}_{2,5}$ no centro da cidade de Cerquilho foi de $21,50(5,7) \mu \mathrm{g} / \mathrm{m}^{3}$, e de $36,00(5,40)$ $\mu \mathrm{g} / \mathrm{m}^{3}$ no centro da cidade de Tatuí. Nos períodos medidos na entressafra a concentração média de $\mathrm{MP}_{2,5}$ na cidade de Cerquilho foi $20,97(2,6) \mu \mathrm{g} / \mathrm{m}^{3}$ e na cidade de Tatuí foi de $26,70(8,91) \mu \mathrm{g} / \mathrm{m}^{3}$.

Nos mesmos dias medidos a temperatura e umidade médias no centro da cidade de Cerquilho foram respectivamente, $23,74(0,67)^{0} \mathrm{C}$ e $47,70(7,41) \%$ na safra e $23,83(0,91)^{\circ} \mathrm{C}$ e $54,94(2,85) \%$ na entressafra. A temperatura e umidade médias no centro da cidade de Tatuí foram respectivamente 18,78 $(0,66)^{0} \mathrm{C}$ e $62,70(2,99) \%$ na safra e $22,59(0,41)^{0} \mathrm{C}$ e $74,62(1,66) \%$ na entressafra.

As concentrações médias de $\mathrm{MP}_{2,5}$, medidas no canavial foram elevadas nos 2 períodos, embora maiores no período da safra (Tabela 1). 
As temperaturas medidas no canavial, nos dias das avaliações, foram semelhantes nos dois períodos, com a umidade sendo mais elevada na entressafra (Tabela 1).

Tabela 1 - Concentrações de Material particulado $\left(\mathrm{MP}_{2,5}\right)$, Temperatura $(\mathrm{T})$ e Umidade relativa do ar (URA) no canavial durante os períodos da safra e da entressafra, 2007-2008

\begin{tabular}{lccc}
\hline Variável & $\begin{array}{c}\text { Safra } \\
\mathbf{M}^{1} \pm \mathbf{D P} \mathbf{P}^{2}\end{array}$ & $\begin{array}{c}\text { Entressafra } \\
\mathbf{M} \pm \mathbf{D P}\end{array}$ & $\begin{array}{c}\text { Valor de } \mathbf{p} \\
\text { Test } \mathbf{~}\end{array}$ \\
\hline $\mathbf{M P}_{2,5}\left(\mu \mathrm{g} / \mathrm{m}^{3}\right)$ & $84.69 \pm 23.90$ & $53.20 \pm 14.82$ & $<0,001$ \\
Temperatura $\left({ }^{0} \mathrm{C}\right)$ & $29.02 \pm 4.92$ & $28.47 \pm 3.24$ & 0,500 \\
URA (\%) & $50.38 \pm 13.07$ & $64.82 \pm 10.27$ & $<0,001$ \\
\hline
\end{tabular}

1: Média; 2: Desvio padrão

\subsection{Avaliação do Índice de Sobrecarga Térmica}

Os índices de sobrecarga térmica, avaliadas pelo Índice Bulbo Úmido Termômetro de Globo (IBUTG), estão apresentadas na tabela 2.

Na Tabela 3 são apresentados os valores de IBUTG a cada cinco minutos, no período de maior sobrecarga térmica (das 11:00 às 12:00 horas), que revela valores muito elevados em todos os intervalos medidos. 
Tabela 2 - $\quad$ Valores de Índice Bulbo Úmido Termômetro de Globo (IBUTG) medidos no dia $25 / 11 / 2007$ no canavial

\begin{tabular}{lc}
\hline Horário das medições & $\begin{array}{c}\text { IBUTG } \\
\mathbf{M}^{1}\end{array}$ \\
\hline $08: 10$ as $09: 10$ & 18,14 \\
$09: 10$ as $10: 10$ & 23,77 \\
$10: 10$ as $11: 10$ & 26,92 \\
$11: 10$ as $12: 10$ & 28,43 \\
$12: 10$ as $13: 10$ & 27,96 \\
$13: 10$ as $14: 10$ & 28,23 \\
$14: 10$ as $15: 10$ & 26,87 \\
\hline
\end{tabular}

1: Média

Tabela 3 - Discriminação dos indicadores que compõe o Índice Bulbo Úmido Termômetro de Globo (IBUTG) no período de maior sobrecarga térmica (11:10-12:10 horas) no dia 25/11/2007, no canavial

\begin{tabular}{lcccc}
\hline Hora & $\mathrm{TbU}^{1}\left({ }^{0} \mathbf{C}\right)$ & $\mathrm{TbS}^{2}\left({ }^{\circ} \mathbf{C}\right)$ & $\mathbf{T g}^{3}\left({ }^{\circ} \mathbf{C}\right)$ & IBUTG \\
\hline $11: 10$ & 24,1 & 29,8 & 41,1 & 28,07 \\
$11: 15$ & 23,9 & 28,4 & 40,4 & 27,65 \\
$11: 20$ & 24,0 & 28,6 & 40,8 & 27,82 \\
$11: 25$ & 24,9 & 29,5 & 41,4 & 28,66 \\
$11: 30$ & 24,0 & 30,0 & 43,0 & 28,38 \\
$11: 35$ & 24,7 & 31,3 & 42,8 & 28,85 \\
$11: 40$ & 25,5 & 30,6 & 43,9 & 29,76 \\
$11: 45$ & 24,6 & 30,0 & 44,8 & 29,24 \\
$11: 50$ & 24,0 & 29,9 & 43,4 & 28,48 \\
$11: 55$ & 23,7 & 30,4 & 41,7 & 27,92 \\
$12: 00$ & 24,4 & 31,4 & 40,6 & 28,24 \\
$12: 05$ & 24,2 & 30,5 & 41,9 & 28,46 \\
$12: 10$ & 23,7 & 30,0 & 41,8 & 28,00 \\
\hline MÉDIA & $\mathbf{2 4 , 2 8}$ & $\mathbf{4 2 , 1 2}$ & $\mathbf{2 8 , 4 3}$ \\
\hline
\end{tabular}

1: Termômetro de bulbo úmido; 2: Termômetro de bulbo seco; 3: Termômetro de globo 


\subsection{Avaliações nos trabalhadores}

Foram avaliados 31 trabalhadores no período da safra e reavaliados 28 no período da entressafra. Três trabalhadores se recusaram a retornar para a reavaliação.

A maioria dos trabalhadores avaliados $(54,8 \%)$ mora na cidade de Tatuí, 29,0\% em Guareí e 16,2\% em Cesário Lange. A média de idade foi de 31,2 anos $\pm 6,3$, variando de 21 a 45 anos de idade.

Dos indivíduos avaliados $51,6 \%$ concluíram a $8^{\text {a }}$ série do ensino médio, $38,7 \%$ estudaram até a $4^{a}$ série do ensino fundamental, $6,5 \%$ possuíam o $2^{\circ}$ grau completo e um trabalhador era analfabeto.

Quanto ao tempo de trabalho no corte de cana, a maioria trabalhou entre 2 e 5 safras contínuas (Tabela 4), tendo em média 9,9 anos de trabalho contínuo (variação de 0,5 - 27 anos).

Tabela 4- Distribuição dos cortadores de cana segundo número de safras contínuas e total de safras trabalhadas, $n=31$

\begin{tabular}{lcccccc}
\hline & \multicolumn{3}{c}{ Safras contínuas até 2007 } & \multicolumn{2}{c}{ Total safras trabalhadas } \\
Safra (n+) & Freq $^{1}(\%)$ & \multicolumn{1}{c}{ Freq Acum $^{2}(\%)$} & Freq (\%) & Freq Acum (\%) \\
\hline$<2$ & 04 & $(12,90)$ & 04 & $(12,90)$ & $01(3,22)$ & $01(3,22)$ \\
$\geq 2 \leq 5$ & 14 & $(45,16)$ & 18 & $(58,06)$ & $09(29,03)$ & $10(32,26)$ \\
$>5 \leq 10$ & 07 & $(22,58)$ & 25 & $(80,65)$ & $09(29,03)$ & $19(61,29)$ \\
$>10 \leq 15$ & 03 & $(9,68)$ & 28 & $(90,32)$ & $06(19,36)$ & $25(80,65)$ \\
$>15$ & 03 & $(9,68)$ & 31 & $(100,00)$ & $06(19,36)$ & $31(100,00)$
\end{tabular}

1: Frequência; 2: Frequência acumulada 
O grupo controle selecionado para análise do teste de micronúcleos foi composto por 17 indivíduos, do sexo masculino, com idade média de 34,6 anos (variando de 22-44 anos). Todos moravam na cidade de Tatuí. A maioria dos indivíduos estudou até a $4^{\text {a }}$ série do ensino fundamental (52,94\%), 29,41\% concluiram a $8^{\text {a }}$ série do ensino médio, $11,76 \%$ concluíram o $2^{0}$ grau e um indivíduo estudou apenas um ano.

Este grupo nunca trabalhou no corte de cana, sendo que a maioria $(52,94 \%)$ dos indivíduos trabalhava no ramo de serviços (motorista, jardinagem, vigilante), seguido pelo ramo da construção civil (pedreiro, ajudante gera) com $29,41 \%$.

O peso corpóreo médio dos indivíduos do grupo controle foi de 76,51 $\mathrm{Kg}(55-131)$, com IMC de $25,89 \mathrm{Kg} / \mathrm{m}^{2}(19,90-43,80)$.

Os resultados das avaliações apresentadas a seguir referem-se aos 28 cortadores de cana que participaram das duas avaliações. 


\subsubsection{Exame clínico}

Dezenove trabalhadores eram não fumantes $(68,0 \%)$ e nove $(32,0 \%)$ eram fumantes, com carga tabágica de $7 \pm 4,23$ anos/maço.

Houve um aumento significante de sintomas respiratórios (rinite/prurido nasal e tosse seca), e de câimbras no período da safra em relação à entressafra, conforme visto na Tabela 5. Vale ainda citar que apenas 2 trabalhadores (7\%) não apresentaram queixas no período da safra, contra $14(50 \%)$ no período da entressafra.

Tabela 5 - $\quad$ Referência de sintomas entre os participantes, no período da safra e da entressafra, $\mathrm{n}=28,2007-2008$

\begin{tabular}{lccccc}
\hline Sintomas & N & Safra & \multicolumn{2}{c}{ Entressafra } & \multicolumn{2}{c}{ Valor $\mathbf{p}^{\top}$} \\
\hline Rinite e & 16 & 57,10 & $\mathbf{N}$ & $\%$ & \\
prurido nasal & 07 & 25,00 & 04 & 14,30 & $<0,01$ \\
Tosse seca & 10 & 35,70 & 03 & 3,60 & 0,02 \\
Câimbras & & & & 10,70 & 0,02 \\
\hline
\end{tabular}

1: Teste de Mcnemar

Os trabalhadores apresentaram menor peso e circunferência abdominal no período da safra (Tabela 6). Nesta tabela também nota-se que ao exame clínico a pressão arterial sistólica (PAS) e diastólica (PAD) foram significativamente maiores no período da safra. 
Tabela 6 - Características gerais dos participantes, no período de safra e entressafra, $\mathrm{n}=28$, 2007-2008

\begin{tabular}{|c|c|c|c|}
\hline Variável & Safra & Entressafra & Valor $p$ * \\
\hline $\begin{array}{l}\text { Peso }(\mathrm{Kg}) \\
{\left[\mathrm{Me}^{1}\left(\mathrm{II}^{2}\right)\right]}\end{array}$ & $\begin{array}{c}64,50 \\
(61,00-69,50)\end{array}$ & $\begin{array}{c}67,00 \\
(62,00-73,50)\end{array}$ & $<0,001$ \\
\hline $\begin{array}{l}\mathrm{IMC}^{3}\left(\mathrm{Kg} / \mathrm{m}^{2}\right) \\
\left(\mathrm{M}^{4} \pm \mathrm{DP}^{5}\right)\end{array}$ & $22,6 \pm 2,7$ & $23,39 \pm 2,93$ & $\leq 0,001$ \\
\hline $\begin{array}{l}\text { Circunferência Abdominal (cm) } \\
\text { [Me (IIQ)] }\end{array}$ & $\begin{array}{c}80,00 \\
(75,00-84,00)\end{array}$ & $\begin{array}{c}83,00 \\
(78,00-87,50)\end{array}$ & 0,002 \\
\hline $\begin{array}{l}\text { PAS }^{6}(\mathrm{mmHg}) \\
(\mathrm{M} \pm \mathrm{DP})\end{array}$ & $125,36 \pm 14,81$ & $118,07 \pm 17,8$ & 0,017 \\
\hline $\begin{array}{l}\mathbf{P A D}^{7}(\mathrm{mmHg}) \\
(\mathrm{M} \pm \mathrm{DP})\end{array}$ & $78,00 \pm 12,96$ & $70,57 \pm 13,88$ & 0,003 \\
\hline $\begin{array}{l}\text { Saturação } \mathrm{O}_{2} \text { Basal (\%) } \\
{[\mathrm{Me}(\mathrm{IIQ})]}\end{array}$ & $\begin{array}{c}97,00 \\
(96,00-98,00)\end{array}$ & $\begin{array}{c}98,00 \\
(97,00-98,00)\end{array}$ & 0,225 \\
\hline
\end{tabular}

* Teste-t pareado ou Wilcoxon Rank

1: Mediana, 2: Intervalo interquartil, 3: Índice de massa corpórea; 4: Média, 5: Desvio padrão; 6:

Pressão arterial sistólica; 7: Pressão arterial diastólica

\subsubsection{Exames Laboratoriais gerais}

Apesar de variarem dentro da faixa da normalidade, os valores de sódio e cálcio foram significativamente menores no período da safra, embora a diferença significativa não se observou na análise de regressão multivariada (Tabela 7). No período da safra em 16 trabalhadores os valores de sódio estavam abaixo de $140 \mathrm{mEq} / \mathrm{L}$, contra 6 no período da entressafra. Em relação ao cálcio, no período da safra 14 trabalhadores apresentaram cálcio abaixo de $9 \mathrm{mg} / \mathrm{dl}$ enquanto no período da entressafra não foi detectada dosagem de cálcio abaixo deste valor. 
Tabela 7 - Avaliação laboratorial dos cortadores de cana, nos períodos de safra e entressafra, $n=28,2007-2008$

\begin{tabular}{|c|c|c|c|c|}
\hline Variável & Safra & Entressafra & $\begin{array}{c}\text { Análise } \\
\text { Univariada }^{1}\end{array}$ & $\begin{array}{c}\text { Valor de } p \\
\text { Análise } \\
\text { multivariada }\end{array}$ \\
\hline $\begin{array}{l}\left.\text { Eritrócitos (milhões } \backslash \mathrm{mm}^{3}\right) \\
\left(\mathrm{M}^{3} \pm \mathrm{DP}^{4}\right)\end{array}$ & $5,20 \pm 0,33$ & $5,33 \pm 0,38$ & 0,027 & 0,018 \\
\hline $\begin{array}{l}\mathbf{P C R}^{\star}(\mathrm{mgldL}) \\
{\left[\mathrm{Me}^{5}\left(I I Q^{6}\right)\right]}\end{array}$ & $\begin{array}{c}0,25 \\
(0,16-0,52)\end{array}$ & $\begin{array}{c}0,44 \\
(0,17-1,46)\end{array}$ & $<0,001$ & $<0,001$ \\
\hline $\begin{array}{l}\text { Colesterol Total (mgldL) } \\
(\mathrm{M} \pm \mathrm{DP})\end{array}$ & $159,86 \pm 38,06$ & $151,21 \pm 33,53$ & 0,041 & $\mathrm{NS}^{7}$ \\
\hline $\begin{array}{l}\text { HDL Colesterol (mgldL) } \\
(\mathrm{M} \pm \mathrm{DP})\end{array}$ & $50,04 \pm 10,65$ & $42,50 \pm 8,24$ & $<0,001$ & $<0,001$ \\
\hline $\begin{array}{l}\text { Albumina(g/dL) } \\
(M \pm D P)\end{array}$ & $4,19 \pm 0,22$ & $4,10 \pm 0,15$ & 0,05 & 0,018 \\
\hline $\begin{array}{l}\text { CPK (U/L) } \\
{[\mathrm{Me}(\mathrm{IIQ})]}\end{array}$ & $\begin{array}{c}165,04 \\
(108,50-216,00)\end{array}$ & $\begin{array}{c}129,86 \\
(77,50-170,50)\end{array}$ & $\leq 0,001$ & 0,0001 \\
\hline $\begin{array}{l}\mathrm{DHL}(\mathrm{U} / \mathrm{L}) \\
(\mathrm{M} \pm \mathrm{DP})\end{array}$ & $156,57 \pm 22,03$ & $148,11 \pm 23,86$ & 0,028 & 0,007 \\
\hline $\begin{array}{l}\text { Cálcio (mgldL) } \\
(\mathrm{M} \pm \mathrm{DP})\end{array}$ & $9,13 \pm 0,44$ & $9,33 \pm 0,28$ & 0,013 & 0,006 \\
\hline $\begin{array}{l}\text { Sódio (mEq/L) } \\
{[\mathrm{Me}(I I Q)]}\end{array}$ & $\begin{array}{c}139,64 \\
(138,00-141,00)\end{array}$ & $\begin{array}{c}140,61 \\
(140,00-142,00)\end{array}$ & 0,046 & 0,074 \\
\hline $\begin{array}{l}\text { Fósforo (mEq/L) } \\
{[\mathrm{Me}(\mathrm{IIQ})]}\end{array}$ & $\begin{array}{c}3,11 \\
(2,80-3,30)\end{array}$ & $\begin{array}{c}2,94 \\
(2,60-3,15)\end{array}$ & 0,013 & NS \\
\hline $\begin{array}{l}\text { T. Protrobina (Seg) } \\
(M \pm D P)\end{array}$ & $13,71 \pm 0,82$ & $15,25 \pm 0,92$ & $<0,001$ & $<0,001$ \\
\hline $\begin{array}{l}\text { T. Trombina (Seg) } \\
(\mathrm{M} \pm \mathrm{DP})\end{array}$ & $11,07 \pm 0,58$ & $12,98 \pm 0,50$ & $<0,001$ & $<0,001$ \\
\hline
\end{tabular}

${ }^{*} \mathrm{n}=27$ (excluido em caso com valor muito elevado na entresafra

1: Teste T pareado ou Wilcoxon Rank; 2: Equação de Estimativa Generalizada ajustada por idade, IMC, tempo de trabalho e tabagismo, 3: Média 4: Desvio padrão; 5: Mediana, 6: Intervalo interquartil; 7: Não significativo

O número de Hemácias, o valor da PCR, do Tempo de Protrombina (TP) e do Tempo de Trombina (TT) foram significativamente menores no período da safra (Figuras 9 e 10). 


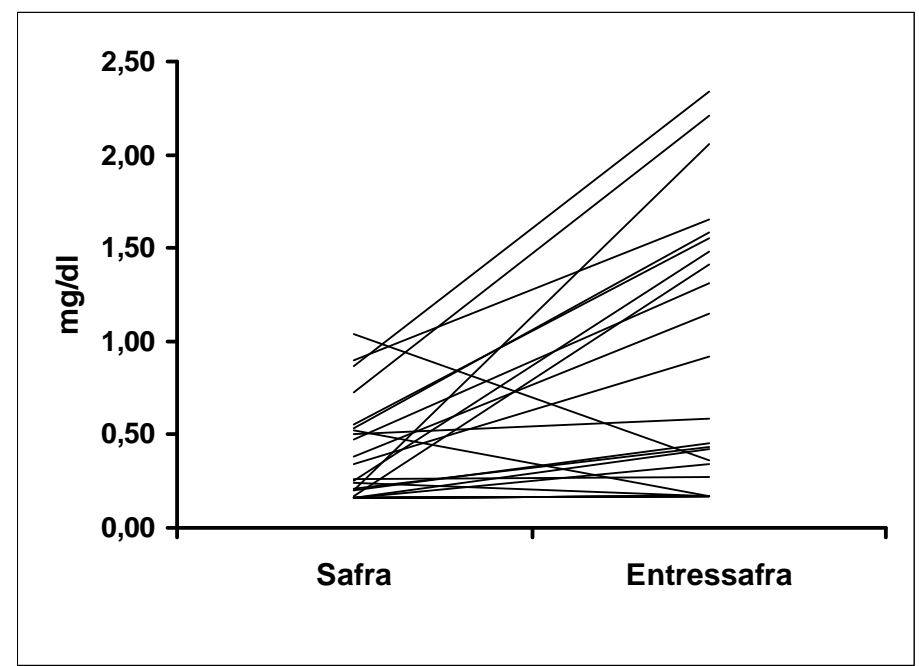

Figura 9- Concentração individual da Proteína C-Reativa, no período da safra e da entressafra

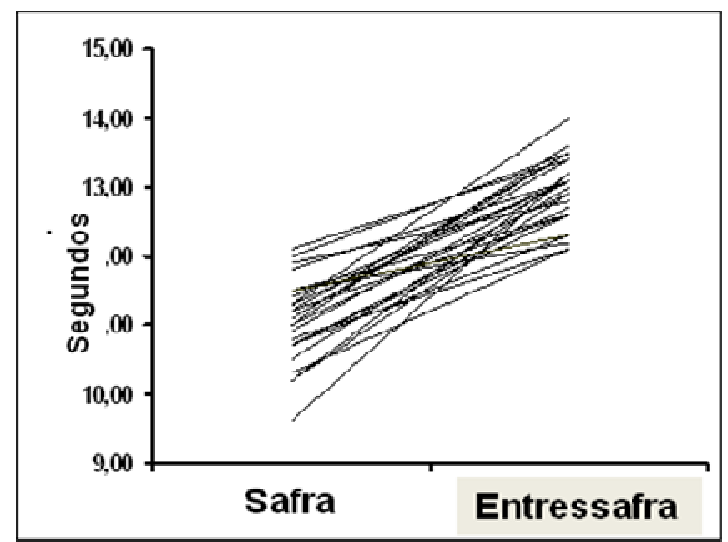

Tempo de Trombina

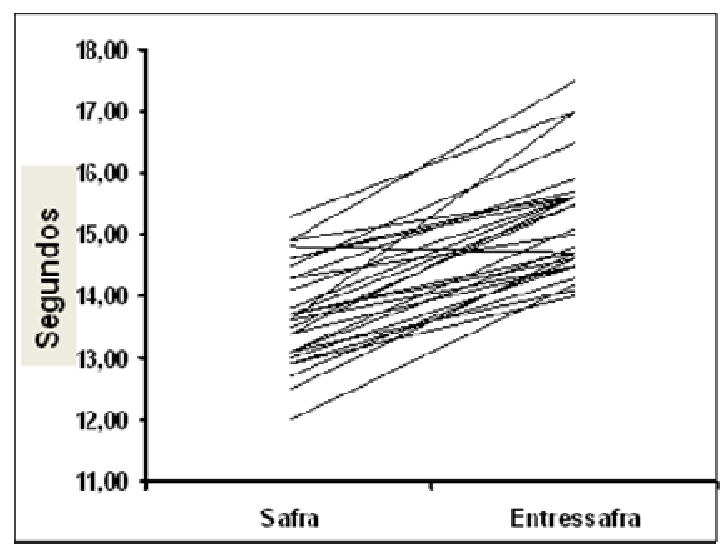

Tempo de Protrombina

Figura 10- Resultado do Tempo de Trombina (A) e Tempo de Protrombina (B), no período da safra e entressafra

As enzimas DHL e CPK, albumina e HDL colesterol apresentaram valores significativamente mais elevados no período da safra (Tabela 7). As demais avaliações laboratoriais realizadas não mostraram diferenças significativas entre os dois períodos estudados (dados totais podem ser vistos no Anexo C). 


\subsubsection{Atividades de enzimas antioxidantes e avaliação de peroxidação lipídica}

A atividade das enzimas Glutationa Transferase (GST) e Glutationa Peroxidase (GPX) foram significativamente maiores na safra embora apenas GPX mantivesse diferença significativa na análise de regressão multivariada. As demais enzimas avaliadas não apresentaram diferenças significativas nos dois períodos estudados, apesar dos valores estarem maiores no período da safra (Tabela 8 e Figura 11).

Tabela 8 - $\quad$ Atividade das enzimas antioxidantes e nível de MDA nos períodos de safra e entressafra, $n=28,2007-2008$

\begin{tabular}{|c|c|c|c|c|}
\hline Variável & Safra & Entressafra & $\begin{array}{c}\text { Análise } \\
\text { Univariada }^{1}\end{array}$ & $\begin{array}{c}\text { Valor de } p \\
\text { Análise } \\
\text { multivariada }\end{array}$ \\
\hline $\begin{array}{l}\mathbf{G S T}^{3}(\mathrm{Ug} / \mathrm{Hb}) \\
\left(\mathrm{M}^{4} \pm \mathrm{DP}^{5}\right)\end{array}$ & $3,383 \pm 1,27$ & $3,01 \pm 1,31$ & 0,019 & $<0,001$ \\
\hline $\begin{array}{l}\mathrm{GPX}^{6}(\mathrm{Ug} / \mathrm{Hb}) \\
(\mathrm{M} \pm \mathrm{DP})\end{array}$ & $55,06 \pm 11,84$ & $39,48 \pm 9,45$ & $<0,001$ & $<0,001$ \\
\hline $\begin{array}{l}\operatorname{SOD}^{7}(\mathrm{KU} / \mathrm{gHb}) \\
(\mathrm{M} \pm \mathrm{DP})^{\star}\end{array}$ & $1,92 \pm 1,18$ & $2,07 \pm 1,25$ & 0,699 & $N S^{8}$ \\
\hline $\begin{array}{l}\mathrm{GR}^{9}(\mathrm{Ug} / \mathrm{Hb}) \\
(\mathrm{M} \pm \mathrm{DP})\end{array}$ & $3,05 \pm 0,97$ & $2,91 \pm 1,13$ & 0,401 & NS \\
\hline $\begin{array}{l}\text { MDA }^{10}(\mu \mathrm{M} / \mathrm{ml}) \\
(\mathrm{M} \pm \mathrm{DP})\end{array}$ & $0,08 \pm 0,001$ & $0,07 \pm 0,001$ & 0,088 & 0,033 \\
\hline \multicolumn{5}{|l|}{${ }^{*} n=23$} \\
\hline
\end{tabular}



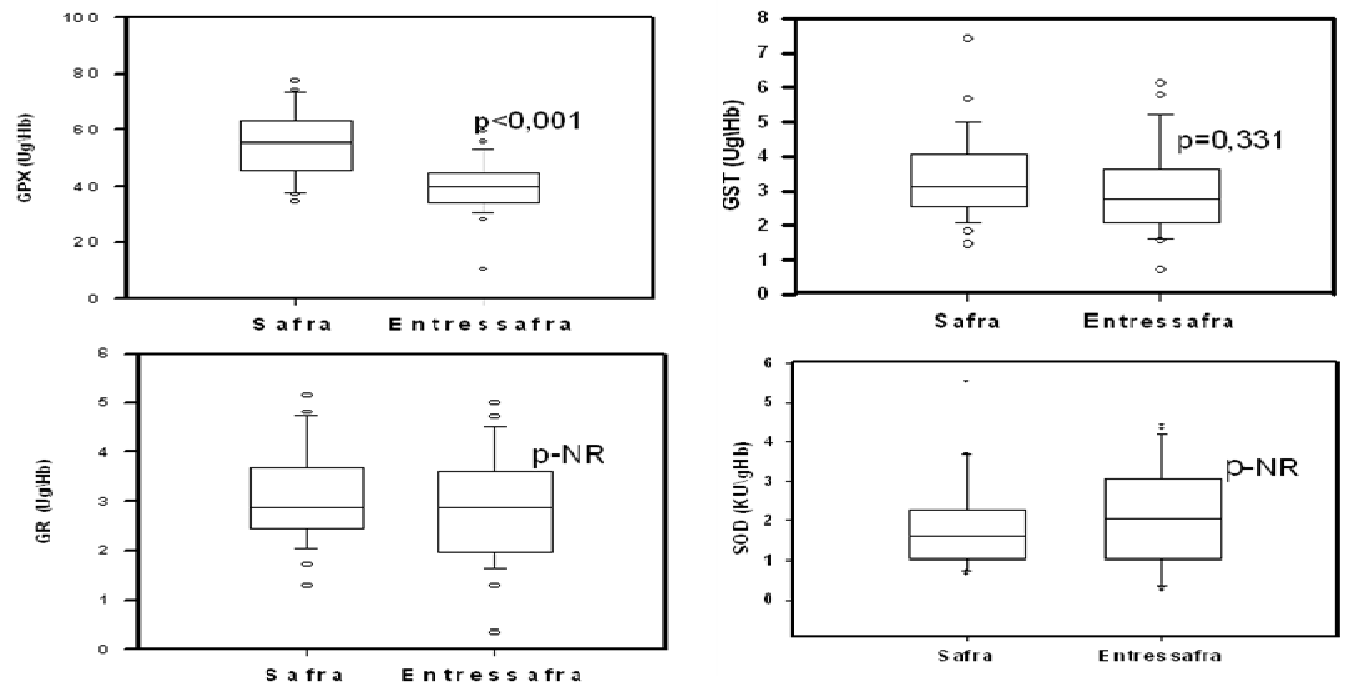

NR-Náo realizado

$p=$ Teste $t$ GEE, ajustadoporiclade, IMC, tempc de serviço e tabagismo

Figura 11 - $\quad$ Atividade das enzimas Glutationa Transferase (GST), Superóxido Desmutase (SOD), Glutationa Redutase (GR) e Glutationa peroxidase (GPX) no período da safra e entressafra

O nível de MDA apresentou valores significativamente mais elevados no período da safra (Tabela 8 e Figura 12).

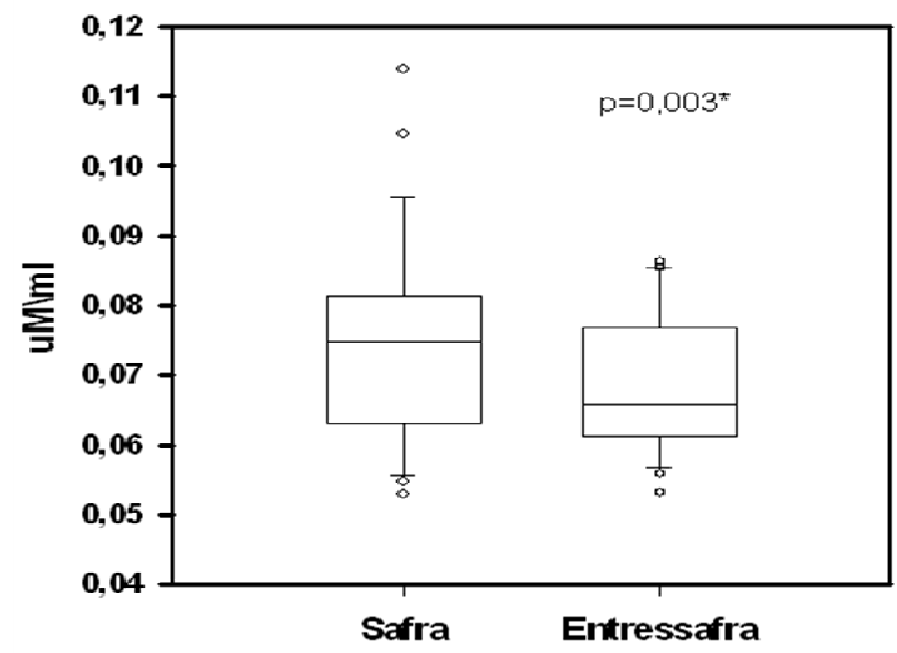

"Valor de p - GEE. ajustado por

Idade. IMC, tempo de trabalho e tabagismo

Figura 12- $\quad$ Níveis da enzima Malondialdeido (MDA), no período da safra e entressafra 


\subsubsection{Prova de Função Pulmonar e Teste de Broncoprovocação}

Embora dentro dos padrões da normalidade, verifica-se que os valores totais e preditos da relação $\mathrm{VEF}_{1} / \mathrm{CVF}, \mathrm{FEF}_{25-75 \%}, \mathrm{FEF}_{25-75 \%} / \mathrm{CVF}$, condutância (SGAW) e difusão de monóxido de carbono (DLCO) foram maiores no período da safra. Já, os valores totais e preditos da resistência (RAW), da capacidade pulmonar total (CPT) e o valor predito da CVF e do volume residual foram mais baixos no período da safra, Tabela 9.

Apenas três trabalhadores apresentaram hiperresponsividade brônquica, um apresentou hiperresponsividade no período da safra, outro na entressafra e o terceiro nos dois períodos estudados. 
Tabela 9- $\quad$ Resultado da Prova de Função Pulmonar nos períodos da safra e entressafra, $\mathrm{n}=28$, 2007-08

\begin{tabular}{|c|c|c|c|c|}
\hline Variável & $\begin{array}{c}\text { Safra } \\
\text { Média } \pm D P^{1}\end{array}$ & $\begin{array}{l}\text { Entressafra } \\
\text { Média } \pm D P\end{array}$ & $\begin{array}{c}\text { Valor-p } \\
\text { Análise } \\
\text { univariada }\end{array}$ & $\begin{array}{c}\text { Valor-p } \\
\text { Análise } \\
\text { multivariada }^{3}\end{array}$ \\
\hline CVF (L) & $4,80 \pm 0,87$ & $4,91 \pm 0,81$ & 0,127 & 0,1002 \\
\hline CVFpred $^{4}(\%)$ & $95,11 \pm 13,54$ & $97,46 \pm 12,75$ & 0,074 & 0,0300 \\
\hline $\operatorname{VEF}_{1}(\mathrm{~L})$ & $3,90 \pm 0,60$ & $4,00 \pm 0,61$ & 0,349 & $N S^{5}$ \\
\hline VEF $_{1}$ pred. (\%) & $94,50 \pm 11,24$ & $94,75 \pm 1,04$ & 0,320 & NS \\
\hline VEF $_{1} / C V F$ & $83,75 \pm 5,85$ & $81,75 \pm 5,89$ & 0,002 & 0,0400 \\
\hline VEF $_{1} /$ CVFpred. (\%) & $99,89 \pm 6,68$ & $97,25 \pm 6,76$ & 0,006 & 0,0618 \\
\hline $\mathrm{FEF}_{25-75 \%}(\mathrm{~L} / \mathrm{seg})$ & $4,26 \pm 0,92$ & $3,95 \pm 0,93$ & 0,013 & 0,0352 \\
\hline $\mathrm{FEF}_{25-75 \%}$ pred (\%) & $87,50 \pm 18,91$ & $81,50 \pm 18,31$ & 0,022 & 0,0207 \\
\hline $\mathrm{FEF}_{25-75 \% / \mathrm{CVF}}$ & $90,89 \pm 23,63$ & $81,79 \pm 21,61$ & $<0,001$ & 0,0016 \\
\hline $\mathrm{FEF}_{25-75 \%} / \mathrm{CVF}(\%)$ & $94,71 \pm 23,85$ & $85,46 \pm 21,67$ & $<0,001$ & 0,0043 \\
\hline SGAW (I/cmH20s) & $0,27 \pm 0,05$ & $0,21 \pm 0,01$ & $<0,001$ & NS \\
\hline SGAW pred (\%) & $136,57 \pm 27,23$ & $102,59 \pm 34,01$ & $<0,001$ & NS \\
\hline RAW (I/cmH20s) & $1,19 \pm 0,31$ & $1,50 \pm 0,37$ & $<0,001$ & $<0,001$ \\
\hline RAW pred (\%) & $52,29 \pm 13,50$ & $66,68 \pm 16,59$ & $<0,001$ & $<0,001$ \\
\hline CPT (litros) & $6,34 \pm 0,95$ & $6,39 \pm 0,93$ & 0,051 & 0,0347 \\
\hline CPTpred (\%) & $89,36 \pm 11,05$ & $91,53 \pm 10,00$ & 0,054 & 0,0157 \\
\hline VR (litros) & $1,30 \pm 0,39$ & $1,48 \pm 0,38$ & 0,179 & 0,0013 \\
\hline VR pred. (\%) & $74,49 \pm 20,93$ & $84,58 \pm 18,19$ & 0,003 & 0,0008 \\
\hline $\mathrm{DLCO}(\mathrm{ml} / \mathrm{min} / \mathrm{mmHg})$ & $41,97 \pm 9,26$ & $37,36 \pm 7,03$ & 0,002 & 0,0001 \\
\hline DLCO pred (\%) & $111,53 \pm 3,89$ & $100,11 \pm 19,49$ & 0,007 & 0,0008 \\
\hline DL/VA & $6,59 \pm 1,29$ & $6,32 \pm 1,16$ & 0,141 & NS \\
\hline DLIVA pred \% & $119,96 \pm 23,78$ & $115,00 \pm 20,24$ & 0,218 & NS \\
\hline
\end{tabular}

1: Test-T pareado ou Wilcoxon Rank, 2: Desvio padrão; 3: Equação de estimativa generalizada ajustado por idade, IMC, tempo de trabalho e tabagismo;; 4: Predito; 5: NS- Não significativo; 


\subsubsection{Teste de Caminhada de 6 minutos}

No Teste de Caminhada, realizado sempre no quarto dia após a chegada a São Paulo, a distância percorrida, a pressão arterial sistólica basal, a pressão arterial diastólica basal e a freqüência cardíaca aos 3 minutos do teste foram significativamente maiores no período da safra (Tabela 10).

Tabela 10 - Resultado do Teste de Caminhada de seis minutos no período da safra e da entressafra, $n=28,2007-2008$

\begin{tabular}{|c|c|c|c|}
\hline Variável & $\begin{array}{c}\text { Safra } \\
\text { Média } \pm D P^{1}\end{array}$ & $\begin{array}{l}\text { Entressafra } \\
\text { Média } \pm D P\end{array}$ & Valor- $p^{2}$ \\
\hline Distância (m) & $694,96 \pm 67,71$ & $675,32 \pm 58,84$ & 0,041 \\
\hline $\mathrm{SPO}_{2}$ Basal (\%) & $97,68 \pm 0,61$ & $97,82 \pm 0,77$ & 0,542 \\
\hline FR $^{3}$. Basal (inc/min) & $17,25 \pm 3,32$ & $17,29 \pm 4,22$ & 0,984 \\
\hline FC $^{4}$. Basal (bat/min) & $78,04 \pm 13,92$ & $76,71 \pm 11,58$ & 0,647 \\
\hline PAS $^{5}$ Basal $(\mathrm{mmHg})$ & $125,36 \pm 14,81$ & $118,07 \pm 17,86$ & 0,017 \\
\hline PAD $^{6}$ Basal $(\mathrm{mmHg})$ & $78,00 \pm 12,96$ & $70,57 \pm 13,88$ & 0,003 \\
\hline $\mathrm{SPO}_{2} 3^{\prime}(\%)$ & $97,14 \pm 1,33$ & $96,86 \pm 1,53$ & 0,330 \\
\hline FC 3' (bat/min) & $121,79 \pm 21,40$ & $111 \pm 21,23$ & 0,037 \\
\hline Borg Dispnéia 6' $(n)$ & $1,64 \pm 1,19$ & $1,11 \pm 1,26$ & 0,054 \\
\hline Borg MMII 6’ (n) & $1,75 \pm 1,40$ & $1,61 \pm 1,62$ & 0,611 \\
\hline $\mathrm{SPO}_{2} 6^{\prime}(\%)$ & $96,75 \pm 1,21$ & $96,86 \pm 1,63$ & 0,571 \\
\hline FR 6' (inc/min) & $25,79 \pm 5,09$ & $24,71 \pm 4,88$ & 0,347 \\
\hline FC 6'(inc/min) & $121,00 \pm 18,87$ & $118,50 \pm 18,31$ & 0,300 \\
\hline PAS 6' (mmHg) & $145,32 \pm 22,76$ & $143,39 \pm 21,97$ & 0,660 \\
\hline PAD 6’' (mmHg) & $89,57 \pm 16,50$ & $88,61 \pm 14,42$ & 0,708 \\
\hline
\end{tabular}

1: Desvio padrão; 2: Teste t pareado; 3: Frequência respiratória; 4: Frequência cardíaca; 5:Pressão arterial sistólica; 6: Pressão arterial diastólica 


\subsubsection{Monitorização Ambulatorial da Pressão Arterial 24 horas}

Em relação à MAPA 24 horas (Tabela 11) os valores pressóricos foram mais elevadas no período da safra, as pressões sistólica nas 24 horas e no sono e a pressão média nas 24 horas na vigília apresentaram diferenças significativas (para ver todos os dados Anexo D).

Tabela 11 - Avaliação da Monitorização Ambulatorial da Pressão Arterial entre os cortadores de cana, no período da safra e da entressafra, $n=28,2007-2008$

\begin{tabular}{|c|c|c|c|c|}
\hline \multirow[b]{2}{*}{ Variável } & \multirow[b]{2}{*}{ Safra } & \multirow[b]{2}{*}{ Entressafra } & \multicolumn{2}{|c|}{ Valor $p$} \\
\hline & & & $\begin{array}{c}\text { Análise } \\
\text { univariada }^{1}\end{array}$ & $\begin{array}{c}\text { Análise } \\
\text { multivariada }^{2}\end{array}$ \\
\hline \multicolumn{5}{|c|}{24 horas } \\
\hline $\begin{array}{l}\text { PAS }^{3}(\mathrm{mmHg}) \\
{\left[\mathrm{Me}^{4}\left(\mathrm{IQ}^{5}\right)\right]}\end{array}$ & $\begin{array}{c}118,00 \\
(112,50-127,50) \\
\end{array}$ & $\begin{array}{c}116,00 \\
(109,50-125,00) \\
\end{array}$ & 0,110 & 0,047 \\
\hline \multicolumn{5}{|c|}{ Sono } \\
\hline $\begin{array}{l}\text { PAS }(\mathrm{mmHg}) \\
\left(\mathrm{M}^{6} \pm D P^{7}\right)\end{array}$ & $111,29 \pm 11,22$ & $107,61 \pm 11,02$ & 0,043 & 0,0254 \\
\hline $\operatorname{PAM}^{8}(\mathrm{mmHg})$ & $78,39 \pm 10,17$ & $76,00 \pm 9,79$ & 0,130 & 0,0866 \\
\hline \multicolumn{5}{|c|}{ Vigília } \\
\hline $\begin{array}{l}\text { PAM (mmHg) } \\
(\mathrm{M} \pm \mathrm{DP})\end{array}$ & $90,57 \pm 10,90$ & $88,00 \pm 8,19$ & 0,103 & 0,0489 \\
\hline
\end{tabular}

1: Teste t pareado ou Wilcoxon Rank ; 2: Equação de estimativa generalizada ajustado por idade, IMC, tempo de trabalho e tabagismo; 3: Pressão arterial sitólica; 4: Mediana; 5: Intervalo interquartil; 6 : Média; 7: Desvio Padrão; 8: Pressão arterial média

Além das médias as medidas de pressão arterial foram mais elevadas em maior número de trabalhadores $(64.3 \%)$ no período da safra em relação à entressafra (Figura 13). Na análise de regressão pelo GEE, no período do sono a pressão sistólica foi significativamente maior no período da safra $(111,3$ vs 107,$6 ; p=0,0254)$. 


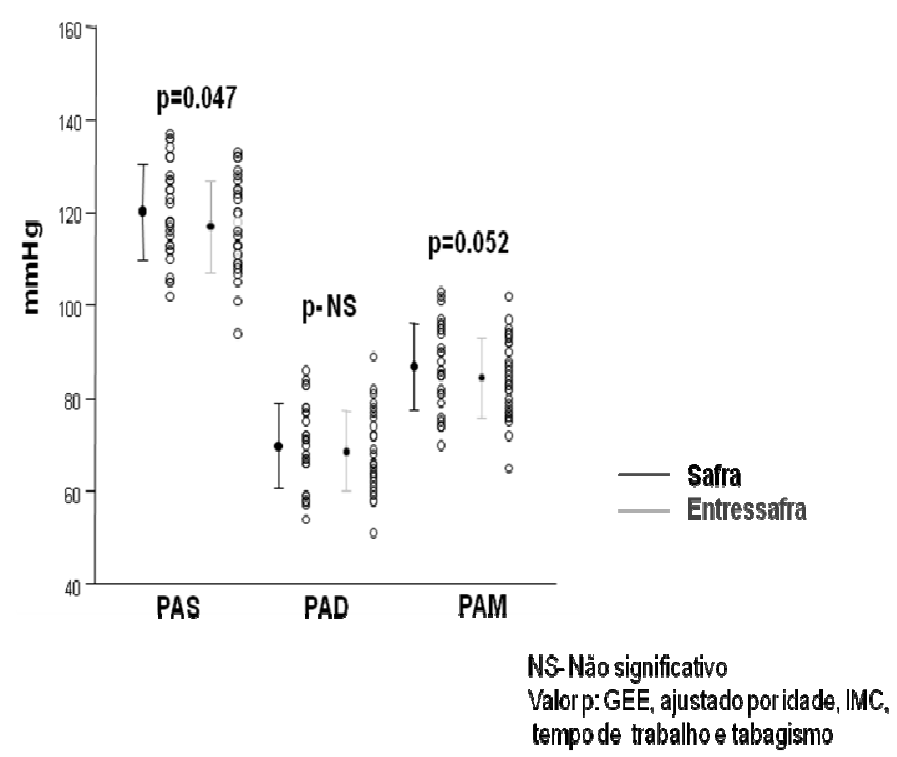

Figura 13- $\quad$ Pressão arterial sistólica, diastólica e média (PAS, PAD, PAM) no MAPA, durante o período da safra e entressafra

\subsubsection{ECG de 24 horas - Holter}

Os indicadores da variabilidade da frequência cardíaca, medidos através do Holter 24 horas, mostram valores significativamente mais elevados no período da safra, com diferenças significativas, para as variáveis SDNN noturno e SDANN nas 24 horas, Tabela 12 (para ver todos os dados, anexo E). 
Tabela 12 - Avaliação do ECG 24 horas, no período da safra e da entressafra, $\mathrm{n}=28,2007-2008$

\begin{tabular}{|c|c|c|c|c|}
\hline \multirow[b]{2}{*}{ Variável } & \multirow[b]{2}{*}{ Safra } & \multirow[b]{2}{*}{ Entressafra } & \multicolumn{2}{|c|}{ Valor $p$} \\
\hline & & & Teste $T^{1}$ & $G E E^{2}$ \\
\hline $\begin{array}{l}\text { SDNN }{ }^{3} \mathbf{2 4} \mathbf{h s}(\mathrm{ms}) \\
\left(\mathrm{M}^{4} \pm D P^{5}\right)\end{array}$ & $187,07 \pm 37,74$ & $178,57 \pm 40,54$ & 0,030 & 0,2168 \\
\hline $\begin{array}{l}\text { SDNN not }{ }^{6}(\mathrm{~ms}) \\
(\mathrm{M} \pm \mathrm{DP})\end{array}$ & $114,57 \pm 36,46$ & $103,11 \pm 28,90$ & 0,047 & 0,0536 \\
\hline $\begin{array}{l}\text { SDANN }^{7} 24 \text { hs } \\
(M \pm D P)\end{array}$ & $161,61 \pm 30,39$ & $148,96 \pm 33,95$ & 0,006 & 0,0176 \\
\hline $\begin{array}{l}\text { SDANN not (ms) } \\
(M \pm D P)\end{array}$ & $55,89 \pm 27,67$ & $44,57 \pm 16,86$ & 0,079 & 0,066 \\
\hline
\end{tabular}

\subsubsection{Shuttle Test}

Os dados do Teste de Caminhada Incremental, Shuttle Test, são apresentados no Anexo F.

A variação das pressões arteriais sistólica e diastólica do início para o final do teste foram maiores no período da safra, porém sem significância estatística. A saturação de $\mathrm{O}_{2}$ e a freqüência cardíaca no término do exercício foram, respectivamente, menores e maiores no período da safra.

\subsubsection{Teste do exercício cardiorrespiratório}

No teste de esforço cardiorrespiratório, verifica-se que a carga de trabalho foi discretamente menor no período da safra em relação à entressafra $(214,54 \times 221,33$ Watts $)$, porém sem diferença significativa (Anexo G). 
$\mathrm{Na}$ Tabela 13, verifica-se que o consumo máximo de oxigênio $\left(\mathrm{VO}_{2}\right.$ max) no pico do exercício mostrou-se significativamente maior no período da safra. $\mathrm{O}$ valor total e predito do pulso de $\mathrm{O}_{2}$ foi significativamente maior no período da safra.

Tabela 13 - Distribuição dos cortadores segundo dados da ergoespirometria, no período da safra e entressafra, $n=24,2007-2008$

\begin{tabular}{|c|c|c|c|c|}
\hline \multirow[b]{2}{*}{ Variável } & \multirow[b]{2}{*}{ Safra } & \multirow[b]{2}{*}{ Entressafra } & \multicolumn{2}{|c|}{ Valor $p$} \\
\hline & & & $\begin{array}{c}\text { Análise } \\
\text { univariada }^{1}\end{array}$ & $\begin{array}{c}\text { Análise } \\
\text { multivariada }^{2}\end{array}$ \\
\hline \multicolumn{5}{|c|}{ Metabolismo } \\
\hline $\begin{array}{l}\mathrm{VO}_{2} \text { Pico }(\mathrm{ml} / \mathrm{Kg} / \mathrm{min}) \\
\left(\mathrm{M}^{3} \pm \mathrm{DP}^{4}\right)\end{array}$ & $40,41 \pm 6,88$ & $36,50 \pm 6,27$ & 0,005 & 0,008 \\
\hline \multicolumn{5}{|c|}{ Cardiovascular } \\
\hline $\begin{array}{l}\text { PAS }^{5} \operatorname{Rep}^{6}(\mathrm{ml} / \mathrm{Kg} / \mathrm{min}) \\
{\left[\operatorname{Me}^{7}\left(I \mathrm{Q}^{8}\right)\right]}\end{array}$ & $\begin{array}{c}130,17 \\
(120,00-140,00)\end{array}$ & $\begin{array}{c}124,54 \\
(120,00-140,00)\end{array}$ & 0,013 & 0,016 \\
\hline $\begin{array}{l}\text { PAS Pico } \\
\mathrm{mmHg}(\mathrm{M} \pm \mathrm{DP})\end{array}$ & $176,56 \pm 29,21$ & $157,50 \pm 20,61$ & 0,001 & $<0,001$ \\
\hline $\begin{array}{l}\text { PAD }^{9} \text { Rep }(\mathrm{mmHg}) \\
{[\mathrm{Me}(\mathrm{IIQ})]}\end{array}$ & $\begin{array}{c}80,00 \\
(80,00-100,00)\end{array}$ & $\begin{array}{c}80,00 \\
(80,00-93,00)\end{array}$ & 0,470 & $\mathrm{NS}^{10}$ \\
\hline $\begin{array}{l}\text { PAD Pico (mmHg) } \\
\text { [Me(IIQ)] }\end{array}$ & $\begin{array}{c}100,00 \\
(80,00-115,00)\end{array}$ & $\begin{array}{c}80,00 \\
(80,00-115,00)\end{array}$ & 0,009 & $<0,001$ \\
\hline $\begin{array}{l}\text { Pulso } \mathrm{O}_{2}(\mathrm{ml} / \mathrm{min} / \mathrm{bat}) \\
{[\mathrm{Me}(\mathrm{IIQ})]}\end{array}$ & $\begin{array}{c}15,50 \\
(14,00-18,50) \\
\end{array}$ & $\begin{array}{c}14,00 \\
(13,00-16,00) \\
\end{array}$ & 0,009 & 0,0007 \\
\hline \multicolumn{5}{|c|}{ Trocas gasosas } \\
\hline $\begin{array}{l}\text { PET CO} ~_{2} \text { Limiar } \mathrm{mmHg}_{(\mathrm{M}} \\
\pm \mathrm{DP})\end{array}$ & $46,88 \pm 2,94$ & $45,42 \pm 2,99$ & 0,037 & 0,021 \\
\hline $\begin{array}{l}\text { RER pico } \\
(\mathrm{M} \pm \mathrm{DP})\end{array}$ & $1,13 \pm 1,00$ & $1,21 \pm 1,00$ & 0,003 & 0,0001 \\
\hline \multicolumn{5}{|c|}{ Ventilatórias } \\
\hline & & & \multicolumn{2}{|c|}{ Valor de $p$} \\
\hline Variável & Safra & Entressafra & $\begin{array}{c}\text { Análise } \\
\text { univariada }^{1}\end{array}$ & $\begin{array}{c}\text { Análise } \\
\text { multivariada }\end{array}$ \\
\hline $\begin{array}{l}\text { VE/VCO } 2 \text { Pico } \\
{[\mathrm{Me}(\mathrm{IIQ})]}\end{array}$ & $\begin{array}{c}24,00 \\
(22,00-25,50) \\
\end{array}$ & $\begin{array}{c}25,2 \\
(23,50-27,00) \\
\end{array}$ & 0,003 & 0,0009 \\
\hline
\end{tabular}

1: Teste T pareado ou Wilcoxon Rank; 2: Equação de estimativas generalizadas, ajustado por idade, IMC, tempo de trabalho e tabagismo 3: Média, 4: Desvio padrão; 5: Pressão arterial sistólica; 6: Repouso; 7: Mediana; 8: intervalo interquartil; 9: Pressão arterial diastólica 10: Não significativo

Em relação à resposta cardiovascular, a freqüência cardíaca apresentou valores menores no período da safra em todas as fases do teste, porém sem significância estatística. 
Ao se analisar o comportamento da pressão durante as 4 fases do exercício (Figura 14) verifica-se aumento significante da PAS e da PAD em relação ao repouso, nos dois períodos, sendo que no período da safra o incremento da PAD durante o exercício foi maior do que o observado no período da entressafra $(\Delta 11,12 \mathrm{mmHg}$ vs $\Delta 5,13, \mathrm{p}<0,001)$.

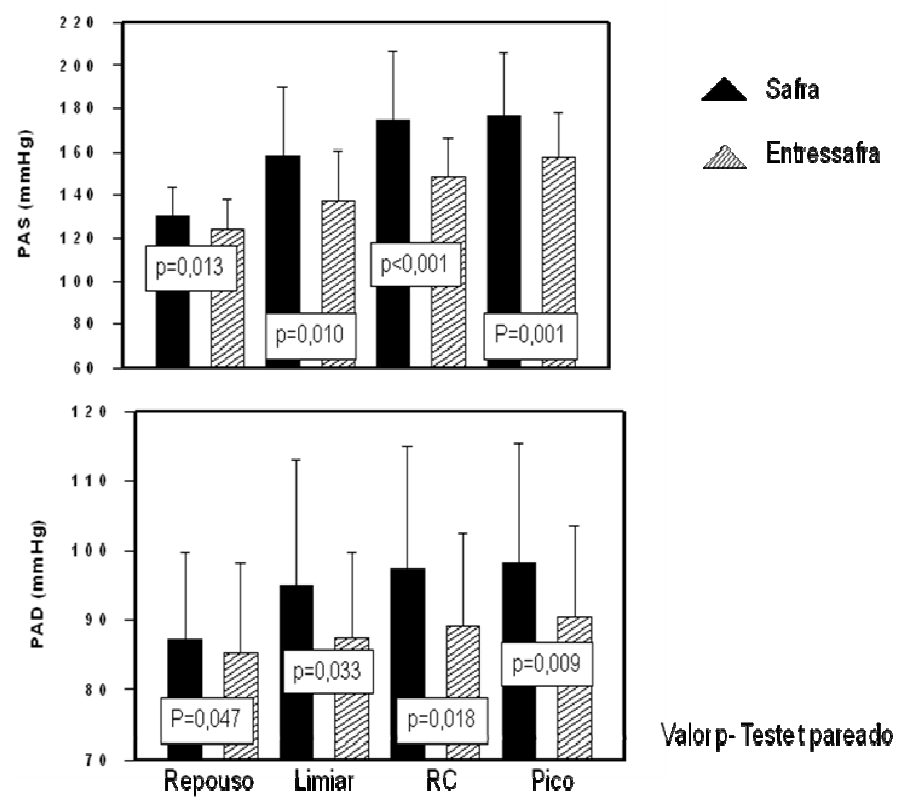

Figura 14- Pressão arterial sistólica e diastólica (PAS,PAD) na Ergoespirometria, durante o período da safra e entressafra, $n=24,2007-2008$ 
A avaliação de resposta reativa da pressão arterial ao exercício verificou-se que durante o período da safra $08(33,33 \%)$ trabalhadores apresentaram índices de pressão elevada ao início do teste contra 04 $(16,67 \%)$ no período da entressafra, $p=0,0285$.

As variáveis ventilatórias, $\mathrm{VE} / \mathrm{VCO}_{2}$, (Tabela 13) apresentaram valores reduzidos no pico do exercício, no período da safra em relação à entressafra, $p<0,05$.

Quanto às trocas gasosas, verifica-se (Tabela 13) que os valores da pressão expiratória final de $\mathrm{CO}_{2}\left(\mathrm{PETCO}_{2}\right)$ no limiar anaeróbio, no ponto de compensação e no pico do exercício foram significativamente maiores no período da safra.

A análise da ergoespirometria por isocarga mostrou que durante o período da safra no final do teste houve um aumento da pressão expiratória final de $\mathrm{CO}_{2}$, mesmo para a mesma ventilação (Figura 15). 

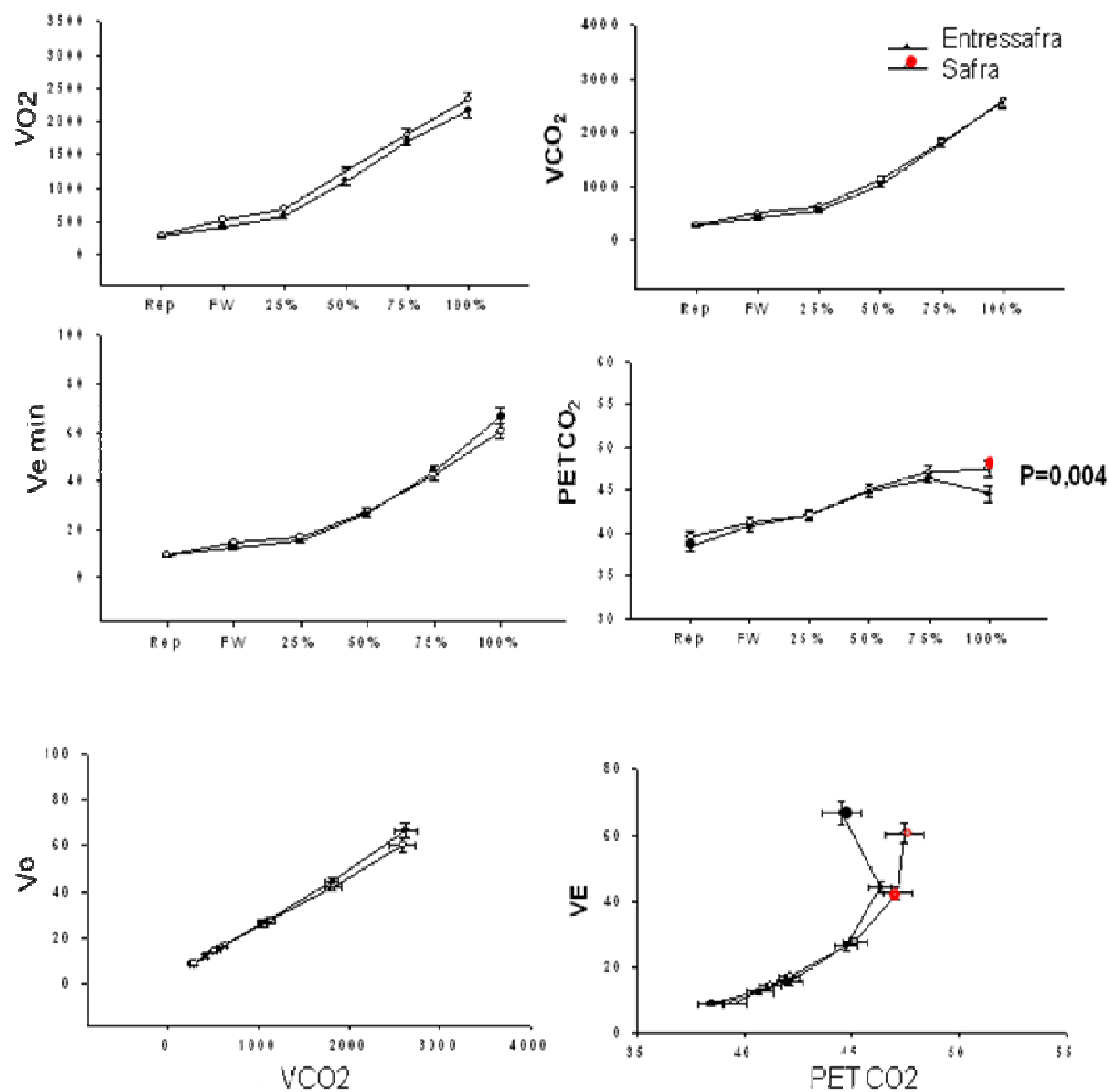

Figura 15 - Ergoespirometria por isocarga, no período da safra e entressafra, $n=24$

Em relação aos sintomas, avaliados através da Escala de Borg Dispnéia, verificou-se que no início do exercício os trabalhadores estavam assintomáticos, nos dois períodos. No pico do exercício o Borg dispnéia foi semelhante, atingindo a média de 5,5 no período da safra e 6,1 no período da entressafra. 


\subsubsection{Avaliação da atividade nervosa simpática muscular (ANSM)}

A freqüência (impulso/min) e a incidência (impulsos/100 bpm) de impulsos da ANSM não revelaram diferenças significantes entre os dois períodos, embora os valores tenderam a ser mais elevados no período da safra, conforme pode ser observado no Anexo $\mathrm{H}$.

\subsubsection{Fluxo sanguíneo muscular}

A análise da reatividade vascular,mostrou valores de fluxo e condutância mais elevados na safra, tanto no baseline como no exercício, entretanto as diferenças não foram estatisticamente significantes (Anexo I). Verifica-se que tanto no baseline como nos três minutos de exercício, os valores da frequência cardíaca foram menores na safra e os níveis de pressão arterial sistólica e diastólica foram mais elevados neste período, entretanto as diferenças não foram estatisticamente significantes.

\subsubsection{VFC e ativação simpática - efeito na pressão sanguínea}

A pressão arterial registrada no MAPA durante o período da safra, em modelo de análise de regressão linear foi significativamente associado com a redução na variabilidade da freqüência cardíaca e aumento da atividade nervosa simpática muscular. A redução de 10ms no SDNN esteve associada a um aumento de 0,73 $\mathrm{mmHg}$ na pressão arterial sistólica e 0,62 $\mathrm{mmHg}$ na pressão arterial diastólica (Tabela 14). 
Tabela 14 - $\quad$ Associação entre Variabilidade da Frequência Cardíaca (VFC) e Atividade Nervosa Simpática Muscular (ANSM) com alteração na pressão arterial

\begin{tabular}{|c|c|c|c|c|c|c|}
\hline & $\mathrm{PAS}^{1} 24 \mathrm{HS}$ & & $\mathrm{PAD}^{2} 24 \mathrm{HS}$ & & PAM $^{3} 24$ HS & \\
\hline Variável & $\begin{array}{l}\text { B } \\
\text { IC }^{5} 95 \%\end{array}$ & p-valor ${ }^{4}$ & $\begin{array}{l}\text { B } \\
\text { IC } 95 \%\end{array}$ & p-valor & $\begin{array}{l}\text { B } \\
\text { IC 95\% }\end{array}$ & p-valor \\
\hline \multicolumn{7}{|l|}{ VFC } \\
\hline $\mathrm{SDNN}^{6}(\mathrm{~ms})$ & $\begin{array}{l}-0.073 \\
-0.15 ;-0.003\end{array}$ & 0.058 & $\begin{array}{l}-0.062 \\
-0.117 ;-0.007\end{array}$ & 0.029 & $\begin{array}{l}-0.071 \\
-0.131 ;-0.011\end{array}$ & 0.02 \\
\hline $\mathrm{rMSSD}^{7}$ (ms) & $\begin{array}{l}-0.221 \\
-0.407 ;-0.035\end{array}$ & 0.019 & $\begin{array}{l}-0.162 \\
-0.299 ;-0.025\end{array}$ & 0.021 & $\begin{array}{l}-0.236 \\
-0.390 ;-0.082\end{array}$ & 0.009 \\
\hline $\mathrm{HF}^{8}$ (ms) & $\begin{array}{l}-0.563 \\
-0.944 ;-0.182\end{array}$ & 0.004 & $\begin{array}{l}-0.369 \\
-0.683 ;-0.055\end{array}$ & 0.021 & $\begin{array}{l}-0.478 \\
-0.814 ; 0.142\end{array}$ & 0.005 \\
\hline $\operatorname{LF}^{9}(\mathrm{~ms})$ & $\begin{array}{l}-0.373 \\
-0.770 ; 0.024\end{array}$ & 0.065 & $\begin{array}{l}-0.300 \\
-0.594 ;-0.006\end{array}$ & 0.046 & $\begin{array}{l}-0.346 \\
-0.684 ;-0.008\end{array}$ & 0.044 \\
\hline $\mathbf{L F} / \mathbf{H F}^{10}$ & $\begin{array}{l}2.829 \\
1.727 ; 3.931\end{array}$ & $<0.0001$ & $\begin{array}{l}2.154 \\
1.517 ; 2.791\end{array}$ & $<0.0001$ & $\begin{array}{l}2.634 \\
1.882 ; 3.387\end{array}$ & $<0.0001$ \\
\hline \multicolumn{7}{|l|}{ ANSM } \\
\hline $30 \% \mathrm{CVM} / \mathrm{bpm}^{11}$ & $\begin{array}{l}0.183 \\
0.013 ; 0.353\end{array}$ & 0.035 & & & $\begin{array}{l}0.159 \\
-1.364 ; 1.682\end{array}$ & 0.041 \\
\hline
\end{tabular}

1: Pressão arterial sistólica; 2: Pressão arterial diastólica; 3: Pressão arterial média; 4: Teste t, ajustado para idade, IMC, tempo de trabalho e tabagismo; 5: Intervalo de confiança; 6: Desvio padrão dos intervalos R-R normais; 7: Raiz quadrada da média dos desvios padrões do intervalo R-R normais; 8: Alta freqüência; 9: Baixa frequência;10: Razão entre baixa freqüência alta freqüência; 11: Atividade simpática muscular a $30 \%$ da contração voluntária máxima ajustada pela frequência cardíaca

\subsubsection{Análise da TCAR}

Apresentamos abaixo (Tabela 15) a prevalência alterações na tomografia segundo os dois leitores. Para os casos discordantes 
apresentamos a prevalência destas alterações em relação a um terceiro leitor.

O índice de Kappa foi baixo para a maior parte das variáveis avaliadas (índices de entre 0,20-0,40). Não ocorreram diferenças nas leituras no período da safra e entressafra, de modo que apresentamos os resultados da primeira leitura (período da safra).

Tabela 15- $\quad$ Número de ocorrências de alterações na leitura das TCAR de tórax entre os cortadores de cana, $n=31,2007$

\begin{tabular}{lcc}
\hline Achados $^{*}$ & \multicolumn{2}{c}{ Presentes } \\
\hline Linfonodos calcificados & No. & 48,39 \\
Placa Pleural & 01 & 3,23 \\
Micronódulos centrolobulares & 22 & 70,97 \\
Espessamento da parede bronquica & 16 & 51,61 \\
Mosaico & 01 & 3,23 \\
Aprisionamento aéreo & 11 & 35,48 \\
\hline
\end{tabular}




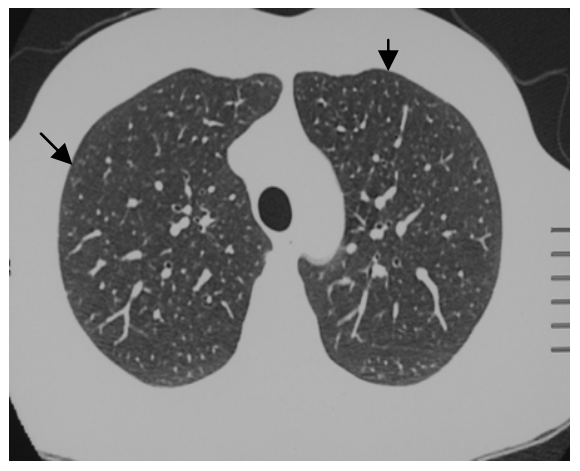

Figura 16 - Presença de micronódulos centrolobulares (setas) em imagem de TCAR de tórax de um cortador de cana (28 a)

\subsubsection{Análise mucociliar nasal - Teste de Sacarina}

A análise mucociliar nasal, através do teste de transporte da sacarina, mostrou um tempo significativamente prolongado no período da safra em relação ao período da entressafra $(p=0,017)$, com valores de $23,4 \pm 14$ minutos e 15,9 \pm 6,7 minutos, respectivamente (Figura 17).

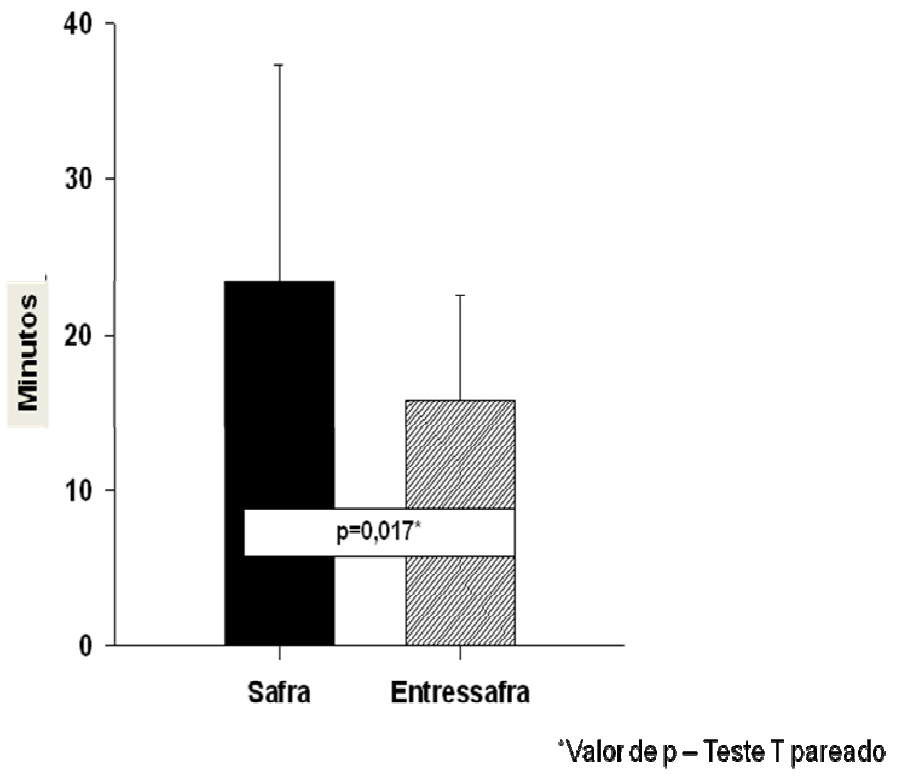

Figura 17- Teste de transporte mucociliar, no período da safra e entressafra 


\subsubsection{Teste de micronúcleos}

O número de micronúcleos observado no raspado da mucosa oral foi menor no período da safra em relação ao período da entressafra $(7,9 \mathrm{X}$ 11,8), porém a diferença não foi significativa. Entretanto ao se fazer a comparação com o grupo controle, a média de micronúcleos observados nos cortadores, tanto no período da safra como da entressafra, foi significativamente maior, $\mathrm{p}<0,05$ (Figura 18).

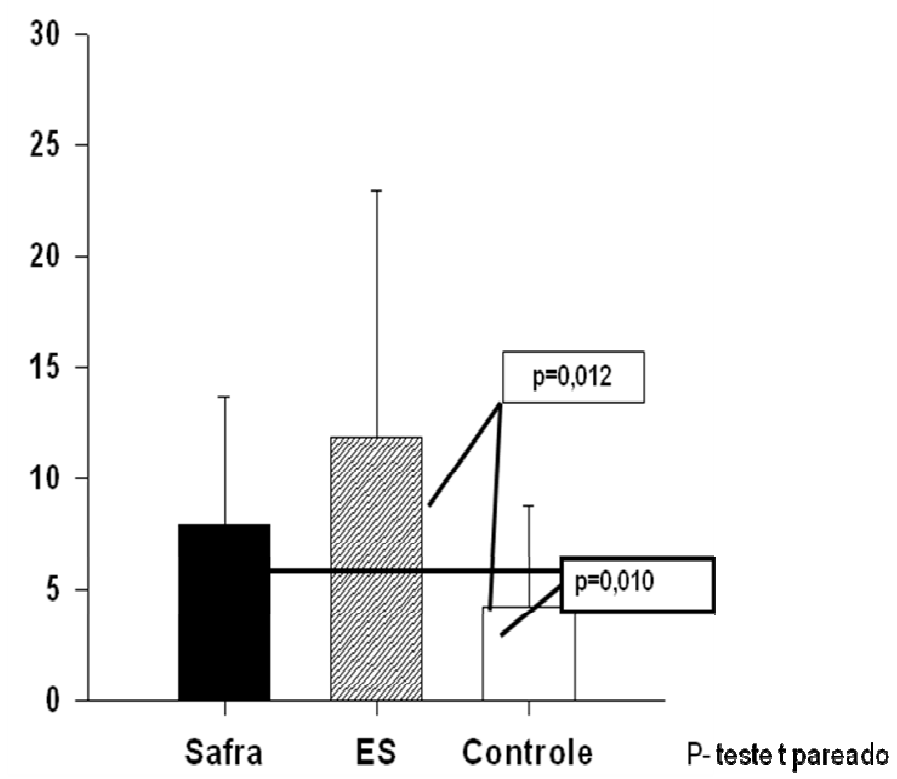

Figura 18- $\quad$ Contagem de micronúcleos (X500 células) entre os cortadoes, no período da safra e entressafra (ES), comparado com o grupo controle

A Figura 19 mostra uma amostra de células da mucosa oral de um cortador de cana sem a presença de micronúcloes $(A)$ e uma amostra de outro cortador, com a presença de micronúcleos. 


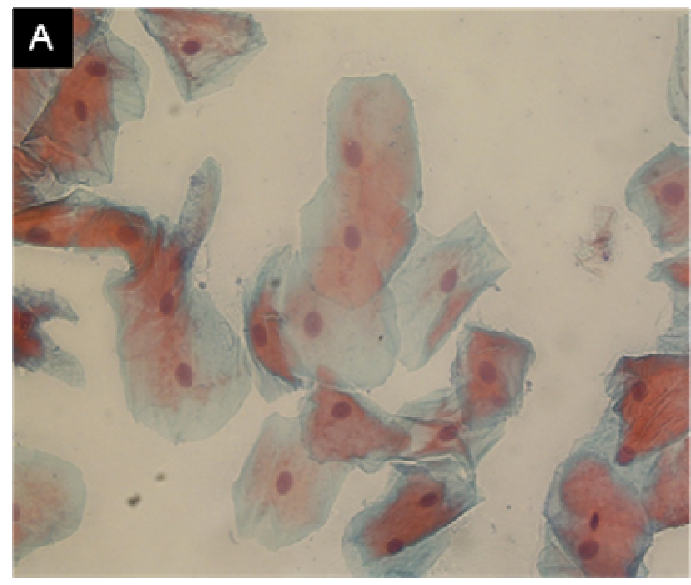

\section{B}

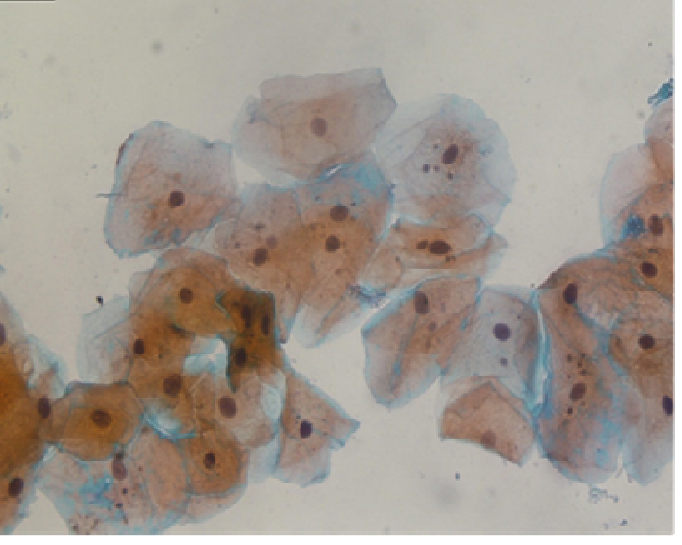

Figura 19- Amostra de células da mucosa oral de cortador. A: Sem micronúcleos; B: Com micronúcleos 


\section{DISCUSSÃo}

O presente estudo tem caráter exploratório e avaliou em dois períodos distintos um grupo de indivíduos adultos jovens, previamente saudáveis, que trabalham no corte de cana de açúcar queimada.

Como se trata do primeiro estudo avaliando efeitos cardiorrespiratórios entre cortadores de cana de açúcar, na tentativa de auxiliar na compreensão dos óbitos que ocorrem nos canaviais paulistas, fizemos opção de usar amplo leque de avaliações, até para fornecer elementos para estudos mais focados no futuro.

Os resultados apresentados evidenciam que estes trabalhadores durante sua atividade laboral, no corte de cana queimada, se expõem a uma série de riscos, tais como esforço físico, altas temperaturas e poluentes. Estas condições combinadas, presentes no período da safra, estiveram associadas a uma maior resposta cardiovascular.

Durante o período da safra o trabalhador realiza esforço físico excessivo, pelo ritmo de trabalho intenso imposto pelo ganho por produção, e pela repetição de tarefas manuais com uso de força. De maneira distinta, no período da entressafra, as atividades impõem um ritmo de trabalho menos intenso por receberem pagamento mensal fixo, pela diversidade de tarefas executadas e por trabalharem 5 dias por semana contra 6 dias no período da safra. Esta observação é percebida pelos cortadores que relataram nas entrevistas trabalho mais extenuante durante o período da safra. 
Laat et al. ${ }^{97}$, em observação sistemática desta atividade fez estimativa que durante uma jornada de trabalho (8 horas) o trabalhador realiza cerca de 4.000 golpes de facão e de flexões do tronco.

As avaliações ambientais realizadas no canavial revelaram concentrações mais elevadas de $\mathrm{MP}_{2,5}$ na safra que na entressafra $(84,69$ $\mu \mathrm{g} / \mathrm{m}^{3}$ vs $53,20 \mu \mathrm{g} / \mathrm{m}^{3}$ ), o que pode ser explicado pelos poluentes liberados na queima da cana, visto não ter havido mudanças climáticas significativas nos dois períodos.

Não existem estudos publicados avaliando a exposição dos cortadores de cana á material particulado, existem estudos que avaliam poluentes em áreas onde a cana é queimada ${ }^{98}$ e nas cidades próximas ${ }^{43}$. Em relação ao período da entressafra os valores de $M_{2,5}$ apesar de estarem mais baixos que no período da safra, são também elevados, provavelmente decorrente da suspensão de material particulado do solo, misturando componentes da terra com resíduos de queimadas de cana dos anos anteriores que nela ficam depositados. Além disto, cerca de $40 \%$ dos trabalhadores não estão ligados a atividades laborais relacionadas ao corte de cana neste período.

Na cidade de Tatuí apesar das concentrações de $\mathrm{MP}_{2,5}$, terem sido duas a três vezes inferiores as encontradas no canavial, elas estão acima da média preconizada pela $\mathrm{OMS}^{99}$ para material particulado para 24 horas, que é de $25 \mu \mathrm{g} / \mathrm{m}^{3}$. Este fato pode decorrer de intenso movimento de caminhões nas cidades para transporte de açúcar e álcool, que também ocorre o período da entressafra. Entretanto, estes dados precisam ser confirmados, 
pois estudo realizado em Piracicaba ${ }^{43}$ revelou valores inferiores nos períodos da safra e entressafra. $\left(22,8 \pm 0,008\right.$ vs $\left.10,00 \pm 0,008 \mu \mathrm{g} / \mathrm{m}^{3}\right)$.

Conforme dados obtidos pelo CllAGRO (órgão oficial de avaliação meteorológica do Estado de São Paulo) $)^{72}$, a temperatura medida na cidade de Tatuí, não sofre grandes variações ao longo do ano, embora seja menor no período do inverno (Anexo). A temperatura média mensal no ano de 2007 foi de 21,7 , com menor valor em julho $\left(16,3^{0} \mathrm{C}\right)$ e o maior em março $\left(25,2^{\circ} \mathrm{C}\right)$. Nos meses de outubro de 2007 a temperatura média foi $24^{\circ} \mathrm{C}$ (variando entre 17 e $30^{\circ} \mathrm{C}$ ), e em abril de 2008 foi de $21^{\circ} \mathrm{C}$ (variando entre 18 e $\left.25^{\circ} \mathrm{C}\right)^{72}$. As medições metereológicas registradas neste estudo mostraram valores próximos a estes, de $20^{\circ} \mathrm{C}$ no período da safra e $22,6^{\circ} \mathrm{C}$ no período da entressafra.

Os valores medidos de IBUTG durante uma jornada de trabalho atingiram até $28,43^{\circ} \mathrm{C}$ (Tabela 2), sendo que a maioria dos valores observados alcançaram níveis acima dos limites preconizados pela legislação brasileira e internacional ${ }^{18,73}$. Valores similares foram encontrados por Laat et al, $\left(27,4^{0} \mathrm{C}\right)^{97}$, em canavial da região de Piracicaba.

Como, durante a safra as atividades são relativamente constantes e as condições de temperatura e umidade na maioria dos dias são semelhantes às do dia medido, provavelmente os trabalhadores enfrentam esta condição adversa em vários dias de trabalho ao longo da safra.

Conforme a legislação brasileira ${ }^{73}$, os valores de IBUTG encontrados para uma atividade laboral considerada pesada, como é o caso do corte de cana-de-açúcar, há necessidade de pausas regulares, para que o trabalho 
possa ser realizado sem comprometimento da saúde do trabalhador (Anexo ) .

O aumento da prevalência de sensação de prurido nasal e tosse seca durante a safra pode estar relacionado ao efeito irritante direto de poluentes $^{100-102}$

Os cortadores também apresentaram maior freqüência de queixa de câimbras no período da safra o que pode ser explicado pelo ritmo de trabalho intenso, sob calor excessivo, facilitando a ocorrência de desbalanço hidroeletrolítico. Este achado tem sido descrito em diversos outros estudos ${ }^{6}$, 10,14

A perda de peso verificado no período da safra (Tabela 6) e o relato da ingestão de 5-10 litros de água durante cada jornada, semelhante aos descrito em outros estudos ${ }^{9}$, sugere uma maior sobrecarga física durante este período.

A análise individual dos resultados dos exames complementares revelou de um modo geral valores dentro da normalidade, nos dois períodos estudados. Entretanto, ao se comparar estes valores por período percebe-se existir diferenças significantes entre eles, o que pode estar associado a condições e riscos existentes na atividade de corte de cana queimada, antes descritos.

A avaliação laboratorial incluiu exames gerais e marcadores inflamatórios que têm sido empregados para avaliar efeitos associados á poluição e a riscos cardiovasculares. Estes exames, apesar de terem sido realizados em amostras de sangue coletados após 60 horas do término da 
última jornada semanal de trabalho, revelaram, durante a safra, um aumento significativo dos níveis de CPK, DHL, hemáceas, HDL colesterol, albumina, fósforo, bem como valores significativamente mais baixos de PCR, cálcio, sódio, e dos tempos de protrombina e trombina.

Indivíduos com bom condicionamento físico e atletas podem apresentar níveis séricos de CPK e DHL no repouso, mais elevados quando comparados com indivíduos sedentários ${ }^{103}$.

A enzima CPK é um indicador de lesão muscular, podendo aumentar durante o exercício intenso, quando ocorre aumento na permeabilidade da membrana celular e liberação desta enzima na matriz intersticial do sistema linfático para o sangue ${ }^{103}$. Estudos em atletas que realizam treinamento físico intenso mostram evidências de agressão e morte de células, mensuradas por elevação desta enzima ${ }^{103,104}$.

Os achados de níveis de CPK mais elevados durante a safra em relação à entressafra, mesmo depois da interrupção do exercício sugere uma situação de persistente elevação de CPK, tais como ocorre em atletas $^{103}$. Condições adversas associadas ao exercício físico como ritmo intenso, calor excessivo podem levar mais facilmente a lesão muscular ${ }^{33,103,}$ 104.

As diferenças encontradas nos valores de albumina, sódio, cálcio e fósforo entre os dois períodos podem estar relacionadas à eventual distúrbio hidroeletrolitico que pode ocorrer durante a safra ${ }^{105-107}$.

A hiponatremia pós esforço físico tem sido estudada entre atletas de elite e militares ${ }^{106,107}$. No sentido de evitar desidratação e assegurar fluidos 
para os tecidos durante uma prova física ou jornada de trabalho, estes profissionais ingerem uma grande quantidade de água e tendem a desenvolver distúrbios hidroeletrolíticos.

Os níveis séricos de fósforo são inversamente proporcionais ao do cálcio, sendo que o controle destes se dá a nível renal. Condições adversas como desidratação, exercício físico intenso, rabdomiólise podem interferir no metabolismo destes minerais ${ }^{108}$.

Os achados clínicos e laboratoriais discutidos até o momento corroboram com a hipótese de que os cortadores de cana tendem a desenvolver uma resposta anormal, não fisiológica, ao esforço físico desempenhado durante a safra. Esta resposta anormal ainda pode ser agravada pela elevada exposição a poluentes ambientais e stress térmico.

O Tempo de Trombina (TT) e de Protrombina (TP) estiveram com valores mais baixos na safra. Tal efeito pode estar relacionado à exposição a poluentes $^{109-111}$.

Baccarelli et al. ${ }^{110}$, mostrou uma associação negativa entre concentração de $\mathrm{MP}_{10}$ e os valores no TP tanto na exposição aguda (1-6 horas antes da coleta de sangue) como também com a concentração média de $\mathrm{MP}_{10}$ nos 30 dias antes da colheita do sangue.

Os achados de Sangani ${ }^{111}$ sugerindo efeito dos metais, presente no MP, na redução do tempo de coagulação podem auxiliar na compreensão dos nossos dados, pois estudo que comparou partículas originadas da queima da cana de açúcar com as de origem veicular, encontrou maior presença de metais na primeira $^{112}$. 
Já em relação ao exercício físico, tem-se estudado o efeito do treinamento na coagulação sanguínea, estando o mesmo associado a melhorias na coagulação sanguínea, particularmente nos fatores de fibrinólise ${ }^{113,114}$. Estudo desenhado para avaliar o comportamento do sistema de coagulação antes e imediatamente após o exercício, mostrou aumento de Tempo de Trombina (TT) e Protrombina (TP) entre indivíduos após o exercício ${ }^{113}$.

Vários estudos tem avaliado a associação entre marcadores inflamatórios, em especial PCR e Fibrinogênio, e exposição à material particulado, com resultados controversos ${ }^{51,115-119}$.

Alguns autores encontraram níveis elevados de PCR associado à poluição ambiental ${ }^{51,115,116}$. Estudo realizado por Hoffmann et al. ${ }^{51}$, mostrou que o aumento anual de $3,91 \mu \mathrm{g} / \mathrm{m}^{3}$ de $\mathrm{PM}_{2,5}$, estava associado a um acréscimo de 23,9\% nos níveis de PCR.

Por outro lado, alguns estudos não demonstraram associação entre exposição a MP e a concentração de $P C R^{117-119}$.

Em artigo de revisão, Kasapis et al. ${ }^{120}$, avaliando efeito do exercício físico sobre PCR e outros marcadores inflamatórios evidencia como efeito agudo do exercício o aumento de níveis de PCR, decorrentes da indução de uma reação inflamatória, e como efeito do treinamento a redução dos níveis desta proteína.

Anderson et al. ${ }^{121}$, em estudo com jovens saudáveis não atléticos, submetidos a treinamento físico constante durante cinco semanas (alpinismo) encontrou redução dos níveis médios de PCR de $1,4 \mathrm{mg} / \mathrm{dl}$ no 
baseline para $0,7 \mathrm{mg} / \mathrm{dl}$ após treinamento. Outro estudo ${ }^{122}$ desenvolvido em indivíduos saudáveis, não atléticos, demonstrou uma redução de 1,3mg/dl dos níveis médios de PCR naqueles indivíduos com PCR basal elevado (acima de 3,0 mg/dl), após 20 semanas de treinamento físico.

A redução dos níveis de PCR no período da safra podem estar revelando um efeito maior do exercício em relação a exposição a poluentes.

Os níveis HDL colesterol estiveram mais elevados no período da safra. Alterações nos níveis de HDL tem sido associado com a intensidade do treinamento de modo que exercício de alta intensidade tende a aumentar os níveis de $\mathrm{HDL}^{123,124}$.

Estudo realizado entre atletas profissionais e amadores, mostrou aumento dos níveis de colesterol total e HDL durante o teste máximo e submáximo entre atletas amadores, mas não em atletas profissionais ${ }^{123}$.

Alterações em eritrócitos e plaquetas tem sido estudada com relação à exposição à material particulado e/ou exercício físico ${ }^{118,125-130}$. Alguns estudos têm mostrado aumento destes componentes sanguíneos em exposição elevada a MP, tanto em estudos com animais ${ }^{125,126}$ como em seres humanos ${ }^{127}$. Entretanto outros não tem revelado associação ${ }^{118,128}$. Quanto ao exercício físico Kabasakalis $A$, et al. $^{130}$ demonstrou que nadadores após realização de ultra-maratona apresentaram aumento de eritrócitos no sangue. Já em outro estudo ${ }^{129}$, mostrou diminuição de plaquetas entre triatletas após 11 meses de treino em relação a grupo de não treinados, sem, entretanto, encontrar alteração na contagem de eritrócitos. 
O aumento da atividade das enzimas antioxidantes, verificados durante o período da safra, pode estar associado a um maior estímulo gerado por radicais oxidantes produzidos pela poluição e/ou pelo exercício exaustivo. O aumento dos níveis de MDA, sugere que apesar de não existir uma depleção enzimática, já ocorre danos celulares, evidenciando a concomitância dos processos.

O estresse oxidativo é uma condição onde ocorre desbalanço entre a produção de radicais livres e sua remoção pelos sistemas de defesa do organismo. Em situações adversas, como hábitos de vida inadequados (tabagismo e alcoolismo), condições ambientais adversas (poluição, temperatura e umidade aumentada), estresse emocional, envelhecimento e exercício fisco extenuante ${ }^{131}$ há um aumento da atividade das enzimas antioxidantes, no sentido de neutralizar a produção aumentada de radicais livres. Se o processo persistir os radicais livres vão consumindo as enzimas antioxidantes que se reduzem se instalando o quadro de estresse oxidativo.

Tem sido atribuído ao estresse oxidativo o principal mecanismo pelo qual o material particulado, em especial partículas ultrafinas, induzem precocemente a processos inflamatórios pulmonares e sistêmicos, como a aterosclerose $\mathrm{s}^{53,109,132,133}$.

O exercício físico pode atuar no estresse oxidativo de forma adversa, com efeito protetor ou indutor da ocorrência do processo. Ferreira et al. ${ }^{131}$, em artigo de revisão discute o papel do exercício físico regular, bem programado como um "protetor" ao estresse oxidativo, aumentando a capacidade de defesa do indivíduo contra lesões oxidativas diversas. Já a 
atividade física mal programada, em intensidade e ritmo excessivo, associada à exaustão, semelhante ao que ocorre no corte de cana durante o período da safra, pode induzir ao desenvolvimento do stress oxidativo $^{26,27,134}$.

A associação entre o exercício físico como efeito protetor e a exposição a poluentes como efeito tóxico na indução do estresse oxidativo também tem sido verificado em estudos experimentais. Estudo com um grupo de ratos submetidos à exposição a poluente pó de carvão mineral e outro grupo submetido a poluente e treinamento físico regular por 12 semanas mostrou diminuição significativa da peroxidação lipídica no grupo treinado $^{135}$

Os achados do nosso estudo sugerem um desbalanço, favorecendo o estresse oxidativo durante o período da safra, que combina maior exposição a poluentes da queima e esforço físico com sobrecarga.

Os valores da prova de função pulmonar apresentaram-se dentro da faixa de normalidade com pequenas variações entre os dois períodos. Vale citar, entretanto, os valores da difusão de monóxido de carbono maiores no período da safra, que pode estar associado a um melhor condicionamento físico neste período, como ocorre em indivíduos atletas ${ }^{136,137}$. Os menores valores de capacidade vital forçada (CVF), capacidade pulmonar total (CPT ) e de volume corrente, este último observado durante o teste do exercício, podem estar associados a exposição a poluentes, como sugerido em estudos experimentais ${ }^{138,139}$. Schelegle at al. ${ }^{138}$, evidenciou que o aumento 
na concentração de ozônio de 180 para 300 ppb e de 200 para 350 ppb leva a uma diminuição de CVF e $\operatorname{VEF}_{1}$.

Apesar de vários estudos ${ }^{140-142}$ sugerirem associação entre exposição a poluentes em ambientes urbanos e maior prevalência de hiperresponsividade brônquica, neste estudo isto não foi comprovado. Tal fato pode estar associado a diferentes características da poluição de origem veicular e de biomassa, associado ao fator exercício.

O TC6M não se mostrou útil para o tipo de população estudada pela sua baixa sensibilidade.

O maior valor da pressão arterial verificado durante o período da safra pode estar associado tanto a efeito de poluentes como verificados em alguns estudos, por ativação simpática ou contração direta das artérias ${ }^{52,143,144}$ bem como ao eventual desbalanço hidroeletrolítico, com repercussão na função renal, decorrente do trabalho com grande despêndio de energia em situação de sobrecarga térmica ${ }^{145,146}$.

Os mecanismos envolvidos na regulação da pressão arterial se dividem conforme a capacidade de resposta, de modo que o sistema neural é responsável pela resposta rápida e o mecanismo hormonal (sistema renina-angiotensina) e renal são responsáveis pelo controle a médio e longo $\operatorname{prazos}^{145,147}$.

No organismo, a ingestão e excreção de líquidos deve ser balanceada, a fim de manter a homeostasia do volume de liquido corporal, o que tem íntima relação com o controle de pressão arterial a longo prazo ${ }^{145,}$ 147,148 . 
Em situações de aumento excessivo do liquido extracelular o sistema renal não é capaz manter o controle fisiológico da pressão e ocorrerá um aumento dos níveis pressóricos. Isto é, a ingestão excessiva de água e/ou sal leva a um aumento do liquido extracelular, com isto vai ocorrer à elevação do volume sistólico, da pressão média de enchimento da circulação e aumento do débito cardíaco, com conseqüente aumento da pressão $\operatorname{arterial}^{145}$.

Vários mecanismos têm sido sugeridos na tentativa de explicar os efeitos dos poluentes na elevação, tanto aguda como crônica, da pressão arterial $^{49,149}$. Três principais mecanismos têm sido sugeridos.

O primeiro mecanismo envolveria estresse oxidativo e processo inflamatório local. A inalação e deposição de $\mathrm{PM}_{2,5}$ nas vias aéreas inferiores, induz a formação de espécies reativas de oxigênio e de nitrogênio que, ao consumirem as reservas antioxidantes, dá início ao estado de estresse oxidativo e à inflamação local ${ }^{49,53,150}$. O estresse oxidativo pulmonar induz a liberação de mediadores pró-inflamatórios pelas células pulmonares indunzindo inflamação, disfunção vascular, aumentando níveis de angiotensina e endotelina (ET) que pode causar vasoconstricção e remodelamento cardíaco ${ }^{49,151}$.

Esta mediação via estresse oxidativo ser levada em consideração, uma vez que neste estudo observou-se aumento de MDA durante o período da safra.

O segundo deles estaria associado ao desbalanço autonômico desencadeado a partir da estimulação de receptores intrapulmonares do 
sistema nervoso autonômico que, via reflexo neural, induziria alterações no sistema cardiovascular com vasoconstrição adrenérgica, aumento do débito cardíaco e pela ativação do sistema renina-angiotensina ${ }^{49}$. O desbalanço autonômico, em favor da atividade simpática, também induziria estresse oxidativo no interior do sistema cardiovascular, levando à disfunção e

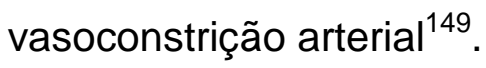

Nossos dados evidenciaram uma associação entre redução da VFC e aumento da ASNM com aumento da pressão arterial, sugerindo possível participação do desbalanço autonômico na gênese do aumento pressórico encontrado, semelhante aos achados sugerido em estudo recém publicado $^{149}$.

O terceiro mecanismo envolveria a passagem direta de partículas ultrafinas para a circulação sistêmica onde induziria estresse oxidativo e processo inflamatório, levando à disfunção vascular ${ }^{49,53}$.

Embora os efeitos dos poluentes no balanço renal do sódio não sejam conhecidos um possível desbalanço hidroeletrolítico decorrente do esforço excessivo em altas temperaturas (como ocorre durante o período da safra) pode ser um fator adicional atuando no sistema renina angiotensina, contribuindo para o aumento da pressão arterial ${ }^{146}$.

Outra hipótese é o aumento crônico dos níveis de vasopressina como resultado da grande ingesta de água após sudorese intensa, ou seja, com a sede já instalada, que ocorre todos os dias durante a jornada. Este aumento pode estar associado ao aumento da pressão arterial, como sugerido em outros estudos $^{152}$. 
A persistente resposta inadequada da pressão diastólica durante o exercício, mesmo durante o período da entressafra, sugere a presença de alterações agudas e crônicas no sistema cardiovascular.

A reprodução em estudo experimental das condições de trabalho desta categoria profissional, bem como a investigação do comportamento renal a exposição a poluentes, na presença de exercício físico, serão passos importantes para auxiliar na compreensão dos mecanismos envolvidos.

A análise isolada dos indicadores de VFC, mostrou aumento de SDNN e SDANN, durante o período da safra, o que pode estar associado ao maior intensidade do exercício realizado neste período cuja resultante superou os efeitos adversos da exposição a poluentes verificados em outros estudos, uma vez que os estudos com poluição demonstram diminuição da VFC em indivíduos expostos a ambientes com maior poluiçãa $45,153,154$. Estudo longitudinal ${ }^{154} \mathrm{em}$ uma corte de 40 trabalhadores de uma fábrica de caldeiras, encontrou uma diminuição de $2,66 \%$ no SDNN para cada aumento de $1 \mathrm{mg} / \mathrm{m}^{3}$ de $\mathrm{MP}_{2,5}$.

Contrariamente, o exercício físico moderado pode influenciar a atividade do sistema nervoso autônomo, aumentando a atividade parassimpática no repouso entre indivíduos treinados ${ }^{155,156}$. Estudo realizado em um grupo de indivíduos saudáveis de diferentes idades, após 12 semanas de treinamento aeróbico verificou aumento da variabilidade da freqüência cardíaca em repouso em todas as faixas etárias, porém com maior potencial em indivíduos mais jovens, enquanto a atividade simpática não apresentou associação com o esforço ${ }^{155}$. 
Os resultados do Shuttle Test sugerem que o uso deste teste na sua forma habitual com a velocidade padrão provavelmente não tem utilidade prática na avaliação destes trabalhadores, pois o teste foi realizado no dobro da velocidade e os indivíduos conseguiram realiza-lo. A dessaturação ocorrida tem sido vista em atletas durante teste de exercício ${ }^{157-159}$.

O aumento da pressão arterial durante o Shuttle Test e a ergoespirometria no período da safra, bem como elevação da pressão diastólica durante o exercício, mesmo na entressafra, sugere um efeito crônico associado a pressão arterial ${ }^{160,161}$. Estes dados, associados ao valor da MAPA, reforçam a idéia de que o trabalho no corte de cana, da maneira aqui descrita, induz a um resposta anormal da pressão arterial.

$\mathrm{Na}$ ergoespirometria também foi encontrado valores de pulso de $\mathrm{O}_{2} \mathrm{e}$ o $\mathrm{VO}_{2}$ máximo maiores no período da safra, o que pode estar associado a um melhor desempenho físico na safra, também verificado pelo menor score da escala de Borg para dispnéia.

$\mathrm{O} \mathrm{VO}_{2}$ máximo é um índice que fornece uma avaliação da capacidade funcional de transporte e utilização de $\mathrm{O}_{2}$, sendo assim utilizado para análise da aptidão física e performance em atletas ${ }^{162,163}$. Avaliação entre atletas ${ }^{163}$ de diferentes categorias e indivíduos sedentários, mostrou que $\quad 0 \quad \mathrm{VO}_{2}$ máximo varia a depender do tipo de treinamento físico efetuado, tendo sido encontrado valores de 37,3 em indivíduos sedentários, 48,67 em indivíduos com bom condicionamento até valores de 67,58 entre maratonistas e 68,75 em ciclistas. Segundo Yazbek-Jr et ${ }^{164}$ adultos com valores de $\mathrm{VO}_{2 \max }$ entre 
20-40 são em geral sedentários e quando apresentam $\mathrm{VO}_{2 \max }$ acima de 40 já indica algum grau de condicionamento físico.

Dentro deste contexto, chama atenção que os níveis médios de $\mathrm{VO}_{2}$ máximo no período da safra foram de 40,41, estando este valor relativamente baixo, se considerarmos a atividade física exercida no corte de cana. Entretanto, estudo realizado em trabalhadores de cana na Colômbia encontrou-se níveis de $\mathrm{VO}_{2}$ max de 42, próximo ao valor aqui encontrado ${ }^{165}$.

A análise da ergoespirometria por isocarga foi verificado que na safra, no pico do exercício houve um aumento da $\mathrm{PET} / \mathrm{CO}_{2}$ mesmo para uma mesma ventilação. Este dado pode estar relacionado a uma tendência a aprisionamento aéreo ao final do exercício no período da safra, o que pode esta associado a maior exposição a poluentes neste período ${ }^{166}$.

A análise isolada da ativação da atividade simpática e reatividade vascular não mostraram diferenças significantes entre os dois períodos, apesar dos níveis elevados de material particulado encontrados. Diversos estudos experimentais e humanos têm mostrado o efeito do material particulado na atividade autonômica e na função endotelial, sendo estes possíveis links para alterações cardiovasculares decorrentes da exposição a material particulado ${ }^{167,168}$.

Neste caso, podemos supor que do mesmo modo que em relação à variabilidade da frequência cardíaca, a atividade física, esteja minimizando o efeito da poluição, quando analisado isoladamente ${ }^{169}$.

A avaliação de alterações na TCAR refletiu nos baixos valores do Índice de Kappa. O tamanho da amostra, a inexistência de um padrão para 
leitura de TCAR, como ocorre, por exemplo, com o RX de tórax para leitura de pneumoconiose devem ter contribuído para este resultado.

O achado de micronódulos e espessamento da parede brônquica entre as TCARs dos cortadores pode estar associado a exposição crônica a poluentes decorrentes da queima de biomassa ${ }^{93,170}$.

O transporte mucociliar (TMC) é um importante mecanismo de defesa do sistema respiratório e está presente do nariz e vias aéreas superiores ao trato respiratório inferior. A eficiência desse mecanismo depende de três componentes, incluindo o cílio (estrutura, número e função), muco (volume e composição) e interação muco-cílio. O teste da sacarina é um método que avalia o transporte mucociliar in vivo no nariz e tem sido correlacionado com o transporte mucociliar traqueobrônquico ${ }^{171}$.

A grande vantagem da utilização da sacarina como marcador é a possibilidade de não utilizar anestésicos, o que pode interferir nos resultados do estudo. Este é um teste simples, pouco invasivo e de baixo custo. A sacarina é cerca de 600 vezes mais doce do que o açúcar e pode ser facilmente detectada quando chega a nasofaringe (em geral porção posterior da língua). O TMC tem sido usado como indicador de defesa pulmonar ${ }^{171-173}$. O valor médio de referência para adultos normais é de 12 minutos ${ }^{174}$.

Vários trabalhos na literatura mostram que a disfunção desse importante mecanismo de defesa por meio de alterações das propriedades físicas e reológicas do muco, cílio e batimento ciliar, e interação muco-cílio está associada à ocorrência de infecções respiratórias e aumento no tempo de internação ${ }^{171,173}$. No nosso estudo, observamos um prolongamento do 
transporte mucociliar nasal durante o período da safra comparado com o período da entressafra. Essa disfunção pode estar associada à agressão dos poluentes atmosféricos advindos da queima de cana-de-açúcar sobre o sistema respiratório, conforme sugere outros estudos ${ }^{43,48}$.

Verificamos aumento na contagem de micronúcleos no grupo de cortadores de cana em relação ao grupo controle.

A poluição ambiental é uma fonte mutagênica para 0 homem. Mutagênese pode ser definida como alterações genéticas que ocorrem no organismo devido à exposição a diversos fatores, entre eles poluição, com capacidade de induzir processos tumorais ${ }^{175}$.

Existe forte evidência da associação entre a freqüência de micronúcleos e a exposição ambiental e/ou ocupacional a agentes genotóxicos, de modo que em situações de exposição a fatores de riscos diversos, como é o caso da poluição ambiental, evidencia-se aumento de micronúcleos ${ }^{175-178}$.

Micronúcleos na mucosa oral é um evento relativamente raro com um média de 1 micronúcleos para cada 1.000 células esfoliadas ${ }^{175}$. Chen et al. ${ }^{177}$, evidenciou que bombeiros apresentaram contagem de micronúcleos (3,91 por 1.000) elevados, com diferença estatística, quando comparados com grupo controle (1,25 por mil). Celik e $\mathrm{al}^{178}$ comparando a contagem de micronúcleos entre trabalhadores de uma refinaria expostos a derivados de petróleo e um grupo de trabalhadores da mesma empresa, porém não expostos, encontrou aumento significante do número de micronúcleos no primeiro grupo quando comparado com o grupo controle. 
Os nossos resultados corroboram com estes estudos, visto termos verificado que a contagem de micronúcleos foi maior entre os cortadores de cana (nos dois períodos) do que em um grupo de referência utilizado para comparação apenas para esta variável que não tinha história de ter trabalhado no corte. 


\section{LIMITAÇÕES}

O fato de termos realizado um número grande de análise em um número reduzido de trabalhadores, o que aumenta a chance das diferenças, mesmo significantes, se deverem ao acaso. Apesar do número reduzido, optamos por manter as análises dos diversos desfechos, de forma a fornecer elementos para novos estudos.

Não ter sido possível fazer uma escolha aleatória dos participantes, pelas dificuldades dos deslocamentos dos trabalhadores da cidade de origem para São Paulo, onde permaneciam seis dias consecutivos.

Dificuldade de selecionar apenas indivíduos não tabagistas, que era a nossa intenção inicial, pois diminuiria uma variável para controle.

Efeito trabalhador sadio e da dificuldade de se obter um grupo controle na medida em que os cortadores estão expostos a diversos fatores de risco como calor, esforço físico excessivo e poluentes, além das condições sócio demográficas.

$>\mathrm{O}$ curto período de avaliação ambiental, muito embora a homogeneidade do processo de trabalho no corte de cana e dados de outro estudo de nosso grupo (comunicação pessoal), confirmam os valores das concentrações ambientais de $\mathrm{PM}_{2,5}$ encontradas neste estudo. 
- A coleta de sangue e realização de outros exames com variados lag com relação ao ultimo dia trabalhado, pode ter subestimado os efeitos mais agudos (até 24 horas). 


\section{CONCLUSÕES}

$>$ No período da safra a PAS de 24 horas foi maior.

$>$ Houve um aumento da pressão arterial diastólica, na resposta ao exercício, nos dois períodos, sendo maior durante o período da safra.

$>$ Durante o período da safra o teste de esforço, o aumento da variabilidade de freqüência cardíaca e do HDL colesterol e a diminuição da circunferência abdominal, sugerem efeito da realização de maior exercício físico neste período.

> Valor de CPK, DHL, e alteração de sódio e cálcio pode representar esforço físico em sobrecarga muscular e distúrbio hidroeletrolítico durante a safra.

$>$ As alterações na atividade das enzimas antioxidantes e dos níveis do marcador de peroxidação lipídica sugerem a ocorrência de estresse oxidativo no período da safra.

$>$ Alteração na coagulação durante o período da safra, pode refletir o aumento de poluição neste período.

$>$ A associação entre redução da VFC e ativação simpática com a elevação da pressão arterial sugere a idéia de desbalanço autonômico como um dos mecanismos envolvidos nas alterações pressóricas encontradas.

$>$ O aumento do clearance mucociliar durante o período da safra, sugere efeito tóxico dos poluentes na mucosa nasal. 
$>$ As alterações de imagem, podem estar associadas à exposição crônica a poluentes decorrentes da queima de biomassa.

> A contagem de micronúcleos nas células da mucosa oral sugere possível efeito genotóxico do material particulado.

$>$ Os níveis de material particulado foram maiores no período da safra, entretanto também são elevados no período da entressafra e nas cidades.

$>$ Os índices de IBUTG sugerem sobrecarga térmica durante a atividade de corte de cana de açúcar queimado. 
ANEXOS

\section{ANEXO A}

Ficha Individual - Protocolo Cana - de - açúcar

Instituto do Coração do Hospital das Clínicas da Universidade de São Paulo

Av. Dr. Enéas de Carvalho Aguiar 44, andar AB, Cerqueira César, São Paulo, SP, Tel: 011-30695034/5191

\section{PRIMEIRA AVALIAÇÃO}

Data:

\section{Identificação}

1. Nome:

2. Endereço (rua/av):

Cidade: Telefone

Mora nesta Cidade há quanto tempo

3. Sexo: $M(X) \quad$ 4. Data de nascimento:

5. Você estudou até que série ou ano:

6. Etnia: B ( 1$), \quad \mathrm{N}(2), \mathrm{P}(3)$,

\section{Informações sobre o trabalho no corte de cana}

1. Trabalha em corte de cana desde que ano? (ano que começou pela $1^{\text {a }}$ vez):

2. Trabalha na atual empresa desde que ano?

3. Horário de trabalho: de segunda a sexta-feira:

aos sábados:

4. Você já teve algum acidente no trabalho? Não ( ), Sim ( ), se sim quantas vezes e especifique:

5. Você já teve alguma doença relacionada ao trabalho Não( ), Sim ( ), se sim qual (is):

6. Você toma líquidos durante o trabalho

( ) Água, quantos copos (ou litros):

( ) outros, nome: 
III. Você fuma?

Não ( ) Sim ( )

Se Sim: Quantos cigarros você fuma por dia?

fuma há quanto tempo?

começou a fumar com que idade?

Se parou de fumar: há quanto tempo parou?

- Anos/maço:

IV. Você mora com pessoas que fumam dentro da casa/quarto?

Não（ ), Sim（ ),

Se sim quantos são os fumantes

V. Você toma alguma medicação?

Não ( ), Sim ( ),

Se sim qual o(s) nome (s):

VI. Já fez inalação ou usou bombinhas para falta de ar, tosse ou chiado no peito?

Não ( ), $\operatorname{Sim}($ ),

Se sim quando começou a usar/fazer?

$E$ usa com que freqüência

VII. Você tem alguma doença?

Não ( ), Sim ( ),

se sim qual o(s) nome(s):

VIII. Você toma alguma medicação regularmente?

Não ( ), Sim ( ),

se sim qual o(s) nome(s):

IX- Nos últimos 6 meses você sentiu ou atualmente você sente:

- Chiado no peito

$$
\begin{aligned}
& \text { Não ( ), Sim ( ) } \\
& \text { Não ( ), Sim ( ) }
\end{aligned}
$$

- Tosse seca

- Tosse com catarro

- Falta de ar em repouso 
- Falta de ar quando faz esforço

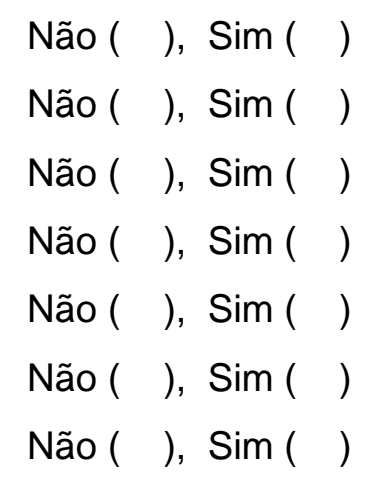

- Espirro frequente

- Coceira no nariz ou na garganta

- Mudança na voz

- Tontura (freqüente)

- Dor de cabeça (freqüente)

- Câimbra (freqüente)

$X$. Alguém na sua família tem ou teve?

- Asma?

Não（）, Sim（）, Não sei （）

- Enfisema ou bronquite crônica?

Não ( ), Sim ( ), Não sei （）

- Infarto do Coração?

Não ( ), Sim ( ), Não sei （）

- Outra doença do coração?

Não ( ), Sim ( ), Não sei ( )

Se sim, qual?

XI. Que data é hoje (dia, mês e ano):

XII. Exame Físico

PA: $\quad$ FC: SatO2: Peso: Altura:

CO exalado: Circunferência abdominal:

Médico examinador 
Anexo B

Ficha Individual - Protocolo Cana - de - açúcar

Instituto do Coração do Hospital das Clínicas da Universidade de São Paulo

Av. Dr. Enéas de Carvalho Aguiar 44, andar AB, Cerqueira César, São Paulo, SP, Tel: 011-30695034/5191

\section{SEGUNDA AVALIAÇÃO}

Data:

\section{Identificação:}

Nome:

Endereço (rua, av.) (em caso de mudança):

Cidade: Telefone:

Sexo: M Idade:

\section{Informações sobre o trabalho}

Quando parou o trabalho no corte de cana?

Depois que parou, qual (is) foram suas atividades?

\begin{tabular}{|l|l|}
\hline Atividade & horário de trabalho \\
\hline & \\
\hline & \\
\hline & \\
\hline
\end{tabular}

Sofreu alguma doença ou acidente de trabalho no trabalho atual?

Não (0), $\quad$ Sim (1)

Se sim, especificar

Atualmente, quantos litros de água bebe, em média, por dia? 
Considera sua atividade atual mais leve ou mais pesada que o corte e por quê?

\section{Situação Tabágica}

Você está fumando ?

( ) Não

( ) Sim

Se sim - quantos cigarro fuma por dia?

- começou a fumar há quanto tempo?

- começou a fumar com que idade?

Se parou: - há quanto tempo parou?

- Anos/maço:

Você mora com pessoas que fumam dentro da casa/quarto?

( ) Não ( ) Sim, quantos?

\section{Antecedentes Mórbidos}

Está usando alguma medicação? ( ) Não, ( ) Sim

Se sim, nome e tempo de uso

Fez uso de inalação ou usou bombinhas para falta de ar ou chiado após a safra?
( ) Não
( ) Sim

Se sim, quando começou a usar

Usa com que freqüência: 
Se sim, qual?

V. Ganhou peso após a safra? （ ) Não （） Sim

Quanto?

VI. Após a safra, você sentiu ou sente:

- Chiado no peito

( ) Não

( ) Sim

- Tosse seca

( ) Não

) Sim

- Tosse com catarro

( ) Não

( ) Sim

- Falta de ar em repouso

( ) Não

( ) Sim

- Falta de ar aos esforços

( ) Não

( ) Sim

- Espirros frequentes

( ) Não

( ) Sim

- Coceira nariz/garganta

( ) Não

( ) Sim

- Mudança na voz

( ) Não

( ) Sim

- Tontura (freqüente)

( ) Não

( ) Sim

- Dor de cabeça (freqüente)

( ) Não

( ) Sim

- Câimbra (freqüente)

( ) Não

( ) Sim

Que data é hoje:

\section{Exame físico}

PA:

CO Exalado:

Circunferência Abdominal:
FC:

Peso:
Sat $\mathrm{O}_{2}$ :

Altura: 
Anexo C

Resultados das avaliações laboratoriais

\begin{tabular}{|c|c|c|c|c|}
\hline Variável & $\begin{array}{c}\text { Safra } \\
\text { Média } \pm D P\end{array}$ & $\begin{array}{l}\text { Entressafra } \\
\text { Média } \pm D P\end{array}$ & Valor-p & $\begin{array}{c}\text { Valor-p } \\
\text { GEE }\end{array}$ \\
\hline $\begin{array}{l}\text { Eritrócitos } \\
\left(\text { milhões } \backslash \mathrm{mm}^{3} \text { ) }\right.\end{array}$ & $5,20 \pm 0,33$ & $5,33 \pm 0,38$ & 0,027 & NS \\
\hline $\begin{array}{l}\text { Hemoglobina } \\
\text { (g\dL) }\end{array}$ & $15,36 \pm 0,85$ & $15,50 \pm 0,81$ & 0,278 & $N S$ \\
\hline $\begin{array}{l}\text { Hematócrito } \\
(\%)\end{array}$ & $46,07 \pm 2,68$ & $46,71 \pm 2,57$ & 0,169 & $N S$ \\
\hline $\begin{array}{l}\text { Leucócitos } \\
\left(\mathrm{mm}^{3}\right)\end{array}$ & $6.121,43 \pm 1.331,21$ & $5807,14 \pm 1157,56$ & 0,196 & $N S$ \\
\hline $\begin{array}{l}\text { Neutrófilos } \\
\left(\mathrm{mm}^{3}\right)\end{array}$ & $3.334,00 \pm 1.123,24$ & $3068,18 \pm 851,66$ & 0,175 & NS \\
\hline $\begin{array}{l}\text { Monócitos } \\
\left(\mathrm{mm}^{3}\right)\end{array}$ & $469,29 \pm 145,59$ & $448,32 \pm 152,07$ & 0,672 & NS \\
\hline $\begin{array}{l}\text { Linfócitos } \\
\left(\mathrm{mm}^{3}\right)\end{array}$ & $1.876,18 \pm 509,50$ & $1857,61 \pm 405,40$ & 0,773 & $N S$ \\
\hline $\begin{array}{l}\text { Eosinófilos } \\
\left(\mathrm{mm}^{3}\right)\end{array}$ & $405,18 \pm 420,79$ & $393,39 \pm 368,14$ & 0,674 & $N S$ \\
\hline $\begin{array}{l}\text { Plaquetas } \\
\left(\mathrm{mm}^{3}\right)\end{array}$ & $237.357 \pm 45.069$ & $230.035 \pm 54.604$ & 0,064 & $N S$ \\
\hline $\begin{array}{l}\text { Fibrinogênio } \\
\text { (mgldL) }\end{array}$ & $252,46 \pm 28,94$ & $261,61 \pm 53,81$ & 0,348 & NS \\
\hline $\begin{array}{l}P^{P C R^{*}} \\
\text { (mgldL) }\end{array}$ & $0,36 \pm 0,26$ & $0,82 \pm 0,73$ & $\leq 0,001$ & 0,001 \\
\hline $\begin{array}{l}\text { Colesterol Total } \\
\text { (mg\dL) }\end{array}$ & $159,86 \pm 38,06$ & $151,21 \pm 33,53$ & 0,041 & NS \\
\hline $\begin{array}{l}\text { HDL Colesterol } \\
\text { (mg\dL) }\end{array}$ & $50,04 \pm 10,65$ & $42,50 \pm 8,24$ & $\leq 0,001$ & 0,00 \\
\hline $\begin{array}{l}\text { LDL Colesterol } \\
\text { (mg } \backslash \mathrm{dL})\end{array}$ & $89,96 \pm 26,05$ & $88,79 \pm 26,99$ & 0,698 & NS \\
\hline $\begin{array}{l}\text { Triglicéridas } \\
\text { (mgldL) }\end{array}$ & $102,57 \pm 64,17$ & $106,68 \pm 91,42$ & 0,663 & NS \\
\hline $\begin{array}{l}\text { Glicemia } \\
\text { (mg\dL) }\end{array}$ & $91,86 \pm 8,25$ & $91,89 \pm 6,77$ & 0,979 & NS \\
\hline Dimero D (ng\mL) & $67,36 \pm 32,59$ & $68,43 \pm 40,61$ & 0,889 & NS \\
\hline $\begin{array}{l}\text { ProteinasTotais } \\
\text { (gldL) }\end{array}$ & $7,45 \pm 0,37$ & $7,48 \pm 0,32$ & 0,798 & $N S$ \\
\hline $\begin{array}{l}\text { Albumina } \\
(\mathrm{g} / \mathrm{dL})\end{array}$ & $4,19 \pm 0,22$ & $4,10 \pm 0,15$ & 0,05 & 0,0180 \\
\hline
\end{tabular}




\begin{tabular}{|c|c|c|c|c|}
\hline $\begin{array}{l}\text { CPK } \\
\text { (U/L) }\end{array}$ & $165,04 \pm 77,69$ & $129,86 \pm 63,48$ & $\leq 0,001$ & 0,0001 \\
\hline $\begin{array}{l}\mathrm{DHL} \\
(\mathrm{U} / \mathrm{L})\end{array}$ & $156,57 \pm 22,03$ & $148,11 \pm 23,86$ & 0,028 & 0,0073 \\
\hline $\begin{array}{l}\text { TGP } \\
\text { (UlL) }\end{array}$ & $39,79 \pm 9,30$ & $40,50 \pm 11,04$ & 0,665 & NS \\
\hline $\begin{array}{l}\text { TGO } \\
\text { (U\L) }\end{array}$ & $23,11 \pm 5,08$ & $22,21 \pm 4,74$ & 0,394 & NS \\
\hline $\begin{array}{l}\text { Acido Úrico } \\
\text { ( } \mathrm{mg} \backslash \mathrm{dL} \text { ) }\end{array}$ & $4,66 \pm 1,04$ & $4,75 \pm 1,12$ & 0,344 & NS \\
\hline $\begin{array}{l}\text { Cálcio } \\
\text { (mg/dl) }\end{array}$ & $9,13 \pm 0,44$ & $9,33 \pm 0,28$ & 0,013 & 0,0059 \\
\hline $\begin{array}{l}\text { Sódio } \\
\text { (mEq/L) }\end{array}$ & $139,64 \pm 2,26$ & $140,61 \pm 1,55$ & 0,046 & 0,0744 \\
\hline Potássio (mEq/L) & $4,72 \pm 0,44$ & $4,58 \pm 0,40$ & 0,139 & 0,1288 \\
\hline $\begin{array}{l}\text { Fósforo } \\
\text { (mEq/L) }\end{array}$ & $3,11 \pm 0,47$ & $2,94 \pm 0,46$ & 0,013 & $N S$ \\
\hline T. Protrobina (seg.) & $13,71 \pm 0,82$ & $15,25 \pm 0,92$ & $\leq 0,001$ & 0,00 \\
\hline T. Trombina (seg) & $11,07 \pm 0,58$ & $12,98 \pm 0,50$ & $\leq 0,001$ & 0,00 \\
\hline $\begin{array}{l}\text { TTPA } \\
\text { (seg) }\end{array}$ & $29,00 \pm 2,08$ & $28,86 \pm 1,68$ & 0,644 & NS \\
\hline INR & $1,05 \pm 0,08$ & $1,06 \pm 0,08$ & 0,268 & $N S$ \\
\hline $\begin{array}{l}\text { Homocisteína } \\
(\mu \mathrm{mol} / \mathrm{L})\end{array}$ & $8,45 \pm 5,18$ & $9,35 \pm 7,82$ & 0,368 & NS \\
\hline $\begin{array}{l}\text { VHS } \\
(\mathbf{m m})\end{array}$ & $4,50 \pm 3,71$ & $5,32 \pm 4,86$ & 0,273 & NS \\
\hline
\end{tabular}




\section{Anexo D}

Resultado da Monitorização Ambulatorial da Pressão Arterial (MAPA)

\begin{tabular}{|c|c|c|c|c|}
\hline Variável & $\begin{array}{c}\text { Safra } \\
\text { Média } \pm \text { DP }\end{array}$ & $\begin{array}{l}\text { Entressafra } \\
\text { Média } \pm \text { DP }\end{array}$ & Valor-p & Valor-p GEE \\
\hline \multicolumn{5}{|c|}{24 horas } \\
\hline PAS (mmHg) & $120,14 \pm 10,31$ & $117,00 \pm 9,96$ & 0,110 & 0,047 \\
\hline PAD (mmHg) & $69,71 \pm 9,05$ & $68,57 \pm 8,70$ & 0,366 & NS \\
\hline PAM (mmHg) & $86,79 \pm 9,41$ & $84,43 \pm 8,57$ & 0,103 & 0,0519 \\
\hline \multicolumn{5}{|c|}{ Vigília } \\
\hline PAS (mmHg) & $124,32 \pm 10,95$ & $121,11 \pm 9,23$ & 0,083 & 0,0448 \\
\hline PAD (mmHg) & $74,04 \mathrm{~V} \pm 9,64$ & $72,0 \pm 7,83$ & 0,240 & NS \\
\hline PAM (mmHg) & $90,57 \pm 10,90$ & $88,00 \pm 8,19$ & 0,103 & 0,0489 \\
\hline \multicolumn{5}{|c|}{ Sono } \\
\hline PAS (mmHg) & $111,29 \pm 11,22$ & $107,61 \pm 11,02$ & 0,043 & 0,0254 \\
\hline PAD (mmHg) & $61,21 \pm 10,02$ & $59,71 \pm 10,39$ & 0,306 & NS \\
\hline PAM (mmHg) & $78,39 \pm 10,17$ & $76,00 \pm 9,79$ & 0,130 & 0,0866 \\
\hline
\end{tabular}




\section{Anexo E}

Resultado do ECG 24 horas (Holter)

\begin{tabular}{|c|c|c|c|c|}
\hline Variável & $\begin{array}{c}\text { Safra } \\
\text { Média } \pm D P\end{array}$ & $\begin{array}{l}\text { Entressafra } \\
\text { Média } \pm D P\end{array}$ & Valor-p & Valor-p GEE \\
\hline $\begin{array}{l}\text { FC media } \\
\text { (bat } \mid \text { min) }\end{array}$ & $68,11 \pm 8,70$ & $67,93 \pm 6,96$ & 0,724 & NS \\
\hline $\begin{array}{l}\text { SDNN } 24 \text { hs. } \\
\text { (ms) }\end{array}$ & $187,07 \pm 37,74$ & $178,57 \pm 40,54$ & 0,030 & 0,2168 \\
\hline $\begin{array}{l}\text { SDÁNN } 24 \text { hs. } \\
\text { (ms) }\end{array}$ & $161,61 \pm 30,39$ & $148,96 \pm 33,95$ & 0,006 & 0,0184 \\
\hline $\begin{array}{l}\text { ASDNN } 24 \text { hs. } \\
\text { (ms) }\end{array}$ & $81,43 \pm 22,22$ & $81,89 \pm 33,95$ & 0,838 & NS \\
\hline $\begin{array}{l}\text { rMSSD } 24 \text { hs } \\
\text { (ms) }\end{array}$ & $47,50 \pm 19,05)$ & $47,61 \pm 19,35$ & 0,957 & NS \\
\hline $\begin{array}{l}\text { pNN50 } 24 \text { hs. } \\
(\%)\end{array}$ & $21,59 \pm 14,21$ & $22,11 \pm 14,59$ & 0,756 & NS \\
\hline $\begin{array}{l}\text { VLF } 24 \text { hs. } \\
(\mathrm{Hz})\end{array}$ & $45,20 \pm 11,80$ & $44,11 \pm 10,26$ & 0,418 & NS \\
\hline $\begin{array}{l}\text { LF } 24 \text { hs. } \\
\text { (Hz) }\end{array}$ & $32,64 \pm 8,15$ & $33,26 \pm 8,36$ & 0,464 & NS \\
\hline $\begin{array}{l}\text { HF } 24 \text { hs. } \\
\text { (Hz) }\end{array}$ & $20,10 \pm 8,23$ & $20,77 \pm 8,65$ & 0,405 & NS \\
\hline $\begin{array}{l}\text { WF } 24 \text { hs. } \\
(\mathrm{Hz})\end{array}$ & $59,92 \pm 15,51$ & $59,68 \pm 14,67$ & 0,880 & NS \\
\hline LH Ratio 24 hs. & $2,00 \pm 1,36$ & $1,75 \pm 0,45$ & 0,608 & NS \\
\hline $\begin{array}{l}\text { SDNN not. } \\
\text { (ms) }\end{array}$ & $114,57 \pm 36,46$ & $103,11 \pm 28,90$ & 0,047 & 0,0536 \\
\hline $\begin{array}{l}\text { SDANN not. } \\
\text { (ms) }\end{array}$ & $55,89 \pm 27,67$ & $44,57 \pm 16,86$ & 0,079 & 0,066 \\
\hline $\begin{array}{l}\text { ASDNN not. } \\
\text { (ms) }\end{array}$ & $88,61 \pm 29,60$ & $85,46 \pm 24,78$ & 0,450 & NS \\
\hline $\begin{array}{l}\text { rMSSD not. } \\
\text { (ms) }\end{array}$ & $64,71 \pm 29,24$ & $62,39 \pm 28,61$ & 0,575 & NS \\
\hline $\begin{array}{l}\text { pNN50 not. } \\
(\%)\end{array}$ & $37,40 \pm 22,60$ & $36,74 \pm 22,31$ & 0,859 & NS \\
\hline $\begin{array}{l}\text { VLF not. } \\
\text { (Hz) }\end{array}$ & $47,56 \pm 14,72$ & $44,78 \pm 11,08$ & 0,222 & NS \\
\hline $\begin{array}{l}\text { LF not. } \\
(\mathrm{Hz})\end{array}$ & $32,48 \pm 11,11$ & $32,20 \pm 9,72$ & 0,861 & NS \\
\hline $\begin{array}{l}\text { HF not. } \\
(\mathrm{Hz})\end{array}$ & $28,26 \pm 13,66$ & $27,58 \pm 12,52$ & 0,712 & NS \\
\hline $\begin{array}{l}\text { WF not. } \\
(\mathrm{Hz})\end{array}$ & $65,33 \pm 20,62$ & $62,77 \pm 7,17$ & 0,364 & NS \\
\hline LH Ratio not. & $1,30 \pm 0,47$ & $1,34 \pm 0,51$ & 0,711 & NS \\
\hline
\end{tabular}

DP- Desvio padrão; NR- Não realizado; Valor-p: Teste t pareado; valor-p GEE: Ajustado por idade, IMC, Tabagismo; SDNN: desvio padrao dos intervalos N-N; SDANN: desvio padrão das médias dos intervalos N-N por 5-5minutes; rMSSD: raiz quadrada da média da diferença dos sucessivos intervalos N-N; LF: Baixa frequencia; HF: Alta frequencia; LH/HF: Razão Baixa freqüência e alta frequencia 


\section{Anexo F}

Resultados do Shuttle Test

\begin{tabular}{|c|c|c|c|c|}
\hline Variável & $\begin{array}{c}\text { Safra } \\
\text { Média } \pm D P\end{array}$ & $\begin{array}{l}\text { Entressafra } \\
\text { Média } \pm D P\end{array}$ & Valor-p & $\begin{array}{l}\text { Valor-p } \\
\text { GEE }\end{array}$ \\
\hline $\begin{array}{l}\text { Distancia } \\
(\mathrm{m})\end{array}$ & $587,14 \pm 197,93$ & $570,00 \pm 186,63$ & 0,516 & NS \\
\hline $\begin{array}{l}\mathrm{SPO}_{2} \text { Basal } \\
(\%)\end{array}$ & $97,86 \pm 0,93$ & $97,82 \pm 0,86$ & 0,890 & NS \\
\hline $\begin{array}{l}\text { Freq Resp Basal } \\
\text { (inc/min) }\end{array}$ & $17,93 \pm 5,35$ & $18,00 \pm 4,52$ & 0,953 & NS \\
\hline $\begin{array}{l}\text { Freq Card Basal } \\
\text { (bat/min) }\end{array}$ & $77,14 \pm 13,93$ & $77,29 \pm 5,73$ & 0,952 & NS \\
\hline $\begin{array}{l}\text { Borg dispnéia term } \\
\text { (n) }\end{array}$ & $3,57 \pm 1,45$ & $3,86 \pm 2,16$ & 1,000 & NS \\
\hline $\begin{array}{l}\text { Borg MMII term } \\
\text { (n) }\end{array}$ & $1,21 \pm 2,23$ & $1,21 \pm 1,34$ & 0,609 & NS \\
\hline $\begin{array}{l}\mathrm{SPO}_{2} \text { term } \\
(\%)\end{array}$ & $92,36 \pm 3,25$ & $93,43 \pm 2,55$ & 0,103 & 0,0270 \\
\hline $\begin{array}{l}\text { Freq Resp Term } \\
\text { (inc/min) }\end{array}$ & $31,07 \pm 6,57$ & $32,04 \pm 7,19$ & 0,349 & NR \\
\hline $\begin{array}{l}\text { Freq Card Term } \\
\text { (bat/min) }\end{array}$ & $162,11 \pm 27,12$ & $147,25 \pm 35,38$ & 0,062 & 0,0477 \\
\hline $\begin{array}{l}\text { Freq Card Max } \\
\text { (bat } / \text { min) }\end{array}$ & $169,29 \pm 11,97$ & $174,18 \pm 13,27$ & 0,129 & NS \\
\hline $\begin{array}{l}\text { Borg dispnéia 2' } \\
\text { após term.(n) }\end{array}$ & $1,50 \pm 1,04$ & $1,75 \pm 1,08$ & 0,312 & NS \\
\hline $\begin{array}{l}\text { Borg MMII 2' após } \\
\text { term (n) }\end{array}$ & $0,82 \pm 1,36$ & $0,93 \pm 1,25$ & 0,860 & NS \\
\hline $\begin{array}{l}\mathrm{SPO}_{2} 2 \text { ' após term } \\
(\%)\end{array}$ & $96,43 \pm 1,50$ & $96,54 \pm 1,29$ & 0,738 & NS \\
\hline $\begin{array}{l}\text { Freq Resp 2'após } \\
\text { term (inc/min) }\end{array}$ & $25,36 \pm 6,23$ & $25,57 \pm 5,37$ & 0,834 & NS \\
\hline $\begin{array}{l}\text { Freq Card 2' após } \\
\text { term (bat/min) }\end{array}$ & $115,57 \pm 18,19$ & $121,64 \pm 17,13$ & 0,067 & 0,1169 \\
\hline $\begin{array}{l}\text { PAS repouso* } \\
(\mathrm{mmHg})\end{array}$ & $122,84 \pm 10,40$ & $121,11 \pm 9,40$ & 0,342 & NS \\
\hline $\begin{array}{l}\text { PAS pico do* } \\
\text { exercício }(\mathrm{mmHg})\end{array}$ & $160,40 \pm 23,62$ & $155,48 \pm 22,90$ & 0,311 & NS \\
\hline $\begin{array}{l}\text { PAD repouso* } \\
(\mathrm{mmHg})\end{array}$ & $72,96 \pm 9,11$ & $72,32 \pm 7,97$ & 0,611 & NS \\
\hline $\begin{array}{l}\text { PAD pico do } \\
\text { exercício* }(\mathrm{mmHg})\end{array}$ & $87,88 \pm 13,22$ & $86,74 \pm 15,08$ & 0,939 & NS \\
\hline
\end{tabular}




\section{Anexo G}

Resultado da ergoespirometria

\begin{tabular}{|c|c|c|c|c|}
\hline Variável & $\begin{array}{c}\text { Safra } \\
\text { Média } \pm D P\end{array}$ & $\begin{array}{l}\text { Entressafra } \\
\text { Média } \pm D P\end{array}$ & Valor-p & $\begin{array}{l}\text { Valor -p } \\
\text { GEE }\end{array}$ \\
\hline $\begin{array}{l}\text { Carga no Pico } \\
\text { (Watts) }\end{array}$ & $214,54 \pm 35,56$ & $221,33 \pm 32,81$ & 0,342 & NS \\
\hline $\begin{array}{l}\text { Carga no Pico } \\
\text { predito (\%) }\end{array}$ & $122,67 \pm 17,63$ & $126,09 \pm 16,97$ & 0,389 & NS \\
\hline \multicolumn{5}{|c|}{ Metabolismo } \\
\hline $\begin{array}{l}\mathrm{V0}_{2} \text { limiar } \\
(\mathrm{ml} / \mathrm{Kg} / \mathrm{min})\end{array}$ & $22,85 \pm 6,54$ & $18,48 \pm 3,73$ & 0,002 & 0,0028 \\
\hline $\begin{array}{l}\mathrm{VO}_{2} \mathrm{RC} \\
(\mathrm{ml} / \mathrm{Kg} / \mathrm{min})\end{array}$ & $34,03 \pm 7,73$ & $29,19 \pm 5,87$ & 0,007 & 0,0110 \\
\hline $\begin{array}{l}\mathrm{VO}_{2} \mathrm{Pico} \\
(\mathrm{ml} / \mathrm{Kg} / \mathrm{min})\end{array}$ & $40,41 \pm 6,88$ & $36,50 \pm 6,27$ & 0,005 & 0,0077 \\
\hline $\begin{array}{l}\mathrm{VO}_{2} \text { pico predito } \\
(\%)\end{array}$ & $108,7 \pm 15,51$ & $102,00 \pm 15,07$ & 0,042 & 0,00 \\
\hline \multicolumn{5}{|c|}{ Cardiovascular } \\
\hline $\begin{array}{l}\text { FC repouso } \\
\text { (bat/min) }\end{array}$ & $76,17 \pm 11,73$ & $76,26 \pm 9,12$ & 0,967 & NS \\
\hline FC Limiar & $124,46 \pm 19,88$ & $116,86 \pm 10,77$ & 0,045 & 0,0326 \\
\hline $\begin{array}{l}\text { FC RC } \\
\text { (bat/min) }\end{array}$ & $153,33 \pm 14,80$ & $151,83 \pm 15,90$ & 0,642 & NS \\
\hline FC Pico (bat/min) & $161,21 \pm 14,12$ & $167,21 \pm 12,75$ & 0,305 & NS \\
\hline $\begin{array}{l}\text { PS Repouso } \\
\text { (mmHg) }\end{array}$ & $130,17 \pm 13,92$ & $124,54 \pm 13,46$ & 0,013 & 0,0157 \\
\hline $\begin{array}{l}\text { PS Limiar } \\
(\mathrm{mmHg})\end{array}$ & $158,25 \pm 31,64$ & $137,50 \pm 23,08$ & 0,010 & 0,0019 \\
\hline $\begin{array}{l}\text { PS RC } \\
(\mathrm{mmHg})\end{array}$ & $174,25 \pm 32,28$ & $148,42 \pm 17,97$ & 0,001 & 0,0000 \\
\hline $\begin{array}{l}\text { PS Pico } \\
(\mathrm{mmHg})\end{array}$ & $176,58 \pm 29,21$ & $157,50 \pm 20,61$ & 0,001 & 0,0000 \\
\hline $\begin{array}{l}\text { PD Repouso } \\
\text { (mmHg) }\end{array}$ & $87,21 \pm 12,65$ & $85,29 \pm 12,96$ & 0,470 & NR \\
\hline PD Limiar (mmHg) & $95,00 \pm 17,94$ & $87,54 \pm 12,33$ & 0,033 & NR \\
\hline $\begin{array}{l}\text { PD RC } \\
(\mathrm{mmHg})\end{array}$ & $97,50 \pm 17,51$ & $89,25 \pm 13,17$ & 0,018 & 0,0006 \\
\hline $\begin{array}{l}\text { PD Pico } \\
(\mathrm{mmHg})\end{array}$ & $98,33 \pm 17,11$ & $90,42 \pm 13,02$ & 0,009 & 0,0001 \\
\hline $\begin{array}{l}\text { Pulso } O_{2} \\
\text { (ml/min/bat) }\end{array}$ & $16,29 \pm 3,00$ & $14,88 \pm 3,15$ & 0,009 & 0,0007 \\
\hline $\begin{array}{l}\text { Pulso } 0_{2} \text { predito } \\
(\%)\end{array}$ & $123,51 \pm 17,84$ & $112,75 \pm 19,08$ & 0,005 & 0,0013 \\
\hline
\end{tabular}




\begin{tabular}{|c|c|c|c|c|}
\hline \multicolumn{5}{|c|}{ Ventilação } \\
\hline VEIVCO ${ }_{2}$ Limiar & $23,79 \pm 1,77$ & $25,21 \pm 2,80$ & 0,004 & 0,0052 \\
\hline $\mathrm{VE} \backslash \mathrm{VCO}_{2} \mathrm{RC}$ & $22,96 \pm 2,05$ & $24,25 \pm 2,03$ & 0,004 & 0,0012 \\
\hline VEIVCO ${ }_{2}$ Pico & $23,96 \pm 2,31)$ & $25,67 \pm \pm 2,65$ & 0,003 & 0,0009 \\
\hline VEIVO ${ }_{2}$ Limiar & $21,86 \pm 1,87$ & $23,63 \pm 2,75$ & 0,005 & 0,0016 \\
\hline$V E \backslash V O_{2} R C$ & $24,54 \pm 3,06$ & $23,33 \pm 3,49$ & 0,004 & 0,0017 \\
\hline VEIVO ${ }_{2}$ Pico & $27,25 \pm 4,51$ & $31,21 \pm 4,96$ & 0,003 & 0,0001 \\
\hline Vt Pico (L) & $2,07 \pm 0,45$ & $2,180,57$ & 0,122 & 0,0747 \\
\hline \multicolumn{5}{|c|}{ Trocas gasosas } \\
\hline $\begin{array}{l}\text { PET CO } \mathrm{CO}_{2} \text { Limiar } \\
(\mathrm{mmHg})\end{array}$ & $46,88 \pm 2,94$ & $45,42 \pm 2,99$ & 0,037 & 0,0213 \\
\hline $\begin{array}{l}\text { PET } \mathrm{CO}_{2} \mathrm{Rc} \\
(\mathrm{mmHg})\end{array}$ & $48,46 \pm 4,08$ & $46,63 \pm 3,06$ & 0,030 & 0,0179 \\
\hline RER pico & $1,13 \pm 1,00$ & $1,21 \pm 1,00$ & 0,003 & 0,0001 \\
\hline \multicolumn{5}{|c|}{ Sintomas } \\
\hline Borg & $5,5 \pm(2,1)$ & $6,1 \pm(2,6)$ & 0,461 & NR \\
\hline
\end{tabular}

PS - Pressão arterial sistólica; PD - Pressão arterial diastólica; DP - Desvio padrão RC - Compensação Respiratória; GEE - Equação de estimativas generalizadas NR - Não realizado 


\section{Anexo H}

Resultado da atividade simpática, no período da safra e entressafra. ( $n=25)$

\begin{tabular}{lccc}
\hline Variável & $\begin{array}{c}\text { Safra } \\
\text { Média } \pm \text { DP }\end{array}$ & $\begin{array}{c}\text { Entressafra } \\
\text { Média } \pm \text { DP }\end{array}$ & Valor-p \\
\hline $\begin{array}{l}\text { ANSM Basal } \\
\text { (estímulos/min) }\end{array}$ & $23,22 \pm 7,54$ & $22,46 \pm(5,06)$ & 0,830 \\
\hline Basal & ANSM 30\% CVM (estímulos/minuto) & 0,061 \\
1' Exercício & $22,93 \pm 6,16$ & $21,64 \pm 4,71$ & 0,486 \\
2' exercício & $27,96 \pm 6,62$ & $24,04 \pm 4,59$ & 0,448 \\
3' exercício & $32,08 \pm 7,64$ & $26,60 \pm 4,42$ & 0,809 \\
\hline & ANSM 30\% CVM/ 100bpm & $31,39 \pm 7,52$ & 0,487 \\
\hline ANSM/100bpm & $38,82 \pm 12,58$ & $36,97 \pm 9,34$ & 0,056 \\
3' exercício & $38,88 \pm 10,99$ & $36,13 \pm 8,59$ & 0,339 \\
1' exercício & $38,20 \pm 10,91$ & $36,02 \pm 8,87$ & 0,440 \\
\hline D' exercício & $40,87 \pm 9,32$ & $38,95 \pm 8,91$ & 0,460 \\
\hline
\end{tabular}

DP- Desvio padrão; ANSM- Atividade nervosa simpática muscular; CVM- Contração voluntária máxima; ANSM 30\% CVM - Atividade nervosa simpática muscular em 30\% da contração voluntária máxima;ANSM 30\% CVM/100bpm - Atividade nervosa simpática muscular em 30\% da contração voluntária máxima, ajustada pela freqüência cardíaca; Valor-p: teste t pareado 
Anexo I

Resultado da avaliação reatividade vascular

\begin{tabular}{|c|c|c|c|}
\hline Variável & $\begin{array}{c}\text { Safra } \\
\text { Média } \pm \text { DP }\end{array}$ & $\begin{array}{l}\text { Entessafra } \\
\text { Média } \pm \text { DP }\end{array}$ & Valor $p$ \\
\hline \multicolumn{4}{|c|}{ Frequencia cardiaca (bpm) } \\
\hline Basal & $59,12 \pm 8,81$ & $60,12 \pm 9,47$ & 0,139 \\
\hline 1’exercício & $65,85 \pm 9,74$ & $66,93 \pm 9,36$ & 0,520 \\
\hline 2' exercício & $68,04 \pm 9,82$ & $68,82 \pm 9,37$ & 0,545 \\
\hline 3' exercício & $69,89 \pm 11,71$ & $71,82 \pm 10,28$ & 0,352 \\
\hline \multicolumn{4}{|c|}{ Pressão Arterial Sistólica (mmHg) } \\
\hline Basal & $145,90 \pm 18,78$ & $143,01 \pm 16,16$ & 0,334 \\
\hline 1 'exercício & $150,52 \pm 17,10$ & $147,89 \pm 17,16$ & 0,393 \\
\hline 2' exercício & $154,52 \pm 16,87$ & $153,07 \pm 17,03$ & 0,360 \\
\hline 3' exercício & $166,33 \pm 17,04$ & $163,59 \pm 14,97$ & 0,443 \\
\hline \multicolumn{4}{|c|}{ Pressão arterial diastólica $(\mathrm{mmHg})$} \\
\hline Basal & $75,30 \pm 12,46$ & $73,16 \pm 10,77$ & 0,218 \\
\hline 1' exercício & $80,41 \pm 11,40$ & $79,52 \pm 10,58$ & 0,467 \\
\hline 2 ‘exercício & $85,44 \pm 10,94$ & $86,19 \pm 10,33$ & 0,699 \\
\hline 3' exercício & $92,59 \pm 11,11$ & $91,04 \pm 12,71$ & 0,547 \\
\hline \multicolumn{4}{|c|}{ Fluxo (ml/min) } \\
\hline Basal & $2,94 \pm 1,39$ & $2,83 \pm 1,15$ & 0,657 \\
\hline 1' exercício & $3,34 \pm 1,53$ & $3,14 \pm 1,41$ & 0,559 \\
\hline 2' exercício & $3,33 \pm 1,79$ & $3,01 \pm 1,33$ & 0,356 \\
\hline 3’ exercício & $3,34 \pm 1,91$ & $3,16 \pm 1,41$ & 0,602 \\
\hline \multicolumn{4}{|c|}{ Condutancia (fluxo/pressão) } \\
\hline Basal & $3,03 \pm 1,36$ & $2,86 \pm 0,81$ & 0,914 \\
\hline 1' exercício & $3,22 \pm 1,45$ & $3,01 \pm 1,26$ & 0,539 \\
\hline 2' exercício & $3,13 \pm 1,54$ & $2,80 \pm 1,11$ & 0,301 \\
\hline 3' exercício & $2,98 \pm 1,72$ & $2,72 \pm 1,01$ & 0,443 \\
\hline
\end{tabular}

DP- Desvio padrão; Valor-p: teste t pareado 


\section{Anexo J}

Temperatura média mensal na cidade de Tatuí, durante os anos de 2007 e 2008.

\begin{tabular}{lcc}
\hline Mês & $\mathbf{2 0 0 7}$ & $\mathbf{2 0 0 8}$ \\
& Temperatura média $\left({ }^{0} \mathbf{C}\right)$ & Temperatura média $\left({ }^{0} \mathbf{C}\right)$ \\
\hline Janeiro & 24,5 & 23,1 \\
Fevereiro & 24,9 & 23,7 \\
Março & 25,2 & 23,7 \\
Abril & 23,3 & 21,0 \\
Maio & 18,2 & 16,5 \\
Junho & 17,6 & 16,5 \\
Julho & 16,3 & 16,9 \\
Agosto & 18,7 & 18,5 \\
Setembro & 22,3 & 20,2 \\
Outubro & 22,5 & 22,9 \\
Novembro & 22,2 & 22,9 \\
Dezembro & 24,2 & 24,0 \\
\hline
\end{tabular}

Fonte: CIAGRO 


\section{ANEXO K}

\section{Quadro 1- Norma de Regulamentação 15, Anexo 3}

Limites de tolerância para exposição ao calor, IBUTG, em regime de trabalho intermitente com períodos de descanso no próprio local de prestação de serviço.

\begin{tabular}{|c|c|c|c|}
\hline $\begin{array}{c}\text { REGIME DE TRABALHO } \\
\text { INTERMITENTE COM } \\
\text { DESCANSO NO PRÓPRIO } \\
\text { LOCAL DE TRABALHO (por } \\
\text { hora) }\end{array}$ & \multicolumn{2}{|c|}{ TIPO DE ATIVIDADE e valores de IBUTG } \\
\cline { 2 - 4 } & LEVE & MODERADA & PESADA \\
\hline Trabalho contínuo & até 30,0 & até 26,7 & Até 25 \\
\hline $\begin{array}{c}45 \text { minutos de trabalho } \\
15 \text { minutos de descanso }\end{array}$ & 30,1 a 30,6 & 26,8 a 28,0 & 25,1 a 25,9 \\
\hline $\begin{array}{c}30 \text { minutos de trabalho } \\
30 \text { minutos de descanso }\end{array}$ & 30,7 a 31,4 & 28,1 a 29,4 & 26,0 a 27,9 \\
\hline $\begin{array}{c}15 \text { minutos de trabalho } \\
45 \text { minutos de descanso }\end{array}$ & 31,5 a 32,2 & 29,5 a 31,1 & 28,0 a 30,0 \\
\hline $\begin{array}{c}\text { Não é permitido o trabalho, sem } \\
\text { a adoção de medidas } \\
\text { adequadas de controle }\end{array}$ & acima de 32,2 & acima de 31,1 & acima de 30,0 \\
\hline
\end{tabular}




\section{Anexo L}

Trabalhadores cortadores de cana participantes do projeto

\begin{tabular}{|c|c|c|c|c|c|c|}
\hline Nome & Idade & Peso & Altura & IMC & $\begin{array}{c}\text { Circ. } \\
\text { Abd. }\end{array}$ & Tabagismo \\
\hline A.G & 43 & 68 & 1,71 & 23,26 & 83 & $\mathrm{~N}$ \\
\hline A.S.M & 26 & 63 & 1,71 & 21,55 & 74 & S \\
\hline A.P.P.L & 25 & 76 & 1,73 & 25,39 & 88 & $\mathrm{~N}$ \\
\hline A.D & 28 & 70 & 1,73 & 23,39 & 84 & $\mathrm{~N}$ \\
\hline A.P & 37 & 64 & 1,68 & 22,68 & 60 & $\mathrm{~N}$ \\
\hline A.E.L.C & 21 & 54 & 1,69 & 18,91 & 75 & $\mathrm{~S}$ \\
\hline A.M.O & 35 & 84 & 1,69 & 29,41 & 98 & $\mathrm{~N}$ \\
\hline A.G.S & 29 & 69 & 1,70 & 23,88 & 86 & $\mathrm{~S}$ \\
\hline C.A.G & 23 & 64 & 1,83 & 19,11 & 75 & $\mathrm{~S}$ \\
\hline C.R.A & 25 & 69 & 1,78 & 21,78 & 81 & $\mathrm{~S}$ \\
\hline C.T & 30 & 64 & 1,70 & 22,15 & 76 & $\mathrm{~S}$ \\
\hline A.D & 28 & 76 & 1,75 & 24,82 & 84 & $\mathrm{~N}$ \\
\hline D.B & 41 & 65 & 1,71 & 22,23 & 84,5 & $\mathrm{~N}$ \\
\hline E.A & 36 & 84 & 1,71 & 28,73 & 100 & $\mathrm{~N}$ \\
\hline E.F.S & 29 & 75 & 1,83 & 22,40 & 84 & $\mathrm{~N}$ \\
\hline EAA & 34 & 65 & 1,69 & 22,76 & 78 & $\mathrm{~N}$ \\
\hline E.F.D & 23 & 68 & 1,76 & 21,95 & 82 & $\mathrm{~N}$ \\
\hline F.B.S & 33 & 83 & 1,73 & 27,73 & 97 & $\mathrm{~N}$ \\
\hline G.B.S & 30 & 68 & 1,78 & 21,46 & 79 & $\mathrm{~N}$ \\
\hline I.L.C & 27 & 60 & 1,70 & 20,76 & 79 & $\mathrm{~N}$ \\
\hline J.B.C & 45 & 61 & 1,58 & 24,44 & 84 & $\mathrm{~N}$ \\
\hline J.S.F.S & 28 & 59 & 1,71 & 20,18 & 75 & $\mathrm{~S}$ \\
\hline J.M.C.S & 32 & 64 & 1,70 & 22,15 & 82 & $\mathrm{~N}$ \\
\hline L.C.M & 38 & 61 & 1,75 & 19,92 & 76 & $\mathrm{~N}$ \\
\hline L.C.R.S & 23 & 52 & 1,63 & 19,57 & 69 & $\mathrm{~N}$ \\
\hline L.C.C & 42 & 55 & 1,57 & 22,31 & 75 & $\mathrm{~N}$ \\
\hline N.C.N & 29 & 54 & 1,62 & 20,58 & 69 & $\mathrm{~S}$ \\
\hline O.D.D & 28 & 64 & 1,81 & 19,54 & 79 & $\mathrm{~S}$ \\
\hline
\end{tabular}




\section{Anexo M}

Indivíduos do grupo controle para avaliação de efeito genotóxico- contagem de micronúcleos participantes do projeto

\begin{tabular}{|c|c|c|c|c|c|c|}
\hline Nome & Idade & Peso & Altura & IMC & $\begin{array}{c}\text { Circ. } \\
\text { Abd. }\end{array}$ & Tabagismo \\
\hline H.L & 37 & 89,3 & 1,72 & 30,08 & 99 & $\mathrm{~N}$ \\
\hline C.R.S & 29 & 131 & 1,79 & 40,89 & - & $\mathrm{N}$ \\
\hline C.T.M & 37 & 67,5 & 1,76 & 21,79 & 82 & $\mathrm{~S}$ \\
\hline W.A.W & 30 & 55 & 1,62 & 21 & - & $\mathrm{S}$ \\
\hline A.A.D & 26 & 68,5 & 1,74 & 22,6 & 84 & $\mathrm{~N}$ \\
\hline J.H.S.F & 33 & 68 & 1,63 & 25,6 & - & $\mathrm{N}$ \\
\hline K.A.C & 22 & 65,7 & 1,77 & 21 & 79 & $\mathrm{~S}$ \\
\hline A.A.S & 33 & 67 & 1,71 & 22,9 & 78 & $\mathrm{~N}$ \\
\hline J.V.L & 29 & 112 & 1,74 & 23,7 & 107 & $\mathrm{~S}$ \\
\hline E.M & 44 & 65,5 & 1,57 & 26,6 & 91 & $\mathrm{~N}$ \\
\hline A.F.A & 43 & 63 & 1,58 & 25,2 & 93 & $\mathrm{~N}$ \\
\hline R.S.S & 33 & 67,9 & 1,74 & 22,4 & 87 & $\mathrm{~N}$ \\
\hline R.A.P & 44 & 55,5 & 1,67 & 19,9 & 74 & $\mathrm{~S}$ \\
\hline W.A.S & 42 & 70 & 1,57 & 28,4 & 100 & $\mathrm{~N}$ \\
\hline J.P.F & 30 & 65 & 1,67 & 23,3 & 80 & $\mathrm{~N}$ \\
\hline D.O.P & 34 & 128 & 1,71 & 43,8 & 125 & $\mathrm{~N}$ \\
\hline F.B.O & 42 & 61,8 & 1,72 & 20,9 & - & $\mathrm{N}$ \\
\hline
\end{tabular}




\section{REFERÊNCIAS}

1. Neves MF, Trombin VG, Consoli M. O mapa sucroenergético do Brasil. In: Souza ELL, Etanol e bioeletricidade: a cana-de-açúcar no futuro da matriz energética. Macedo IC, editor. São Paulo; 2010.

2. UNICA, Uniao das Indústrias de cana de açúcar. Disponível em: http/www.unica.com.br. Acessado em: 20112l2009

3. Ribeiro H. Sugar cane burning in Brazil: respiratory health effects. Rev Saúde Pública. 2008;42(2):1-6.

4. Veiga Filho AA. Estudo do processo de mecanização do corte de cana-de-açúcar: o caso do estado de São Paulo, Brasil. RECITEC. 1999;3(1):74-99.

5. Açúcar ético. Disponível em: http/www.sugraethic.org.br. Acessado em 20.09.09.

6. Alves F. Por que morrem os cortadores de cana. Saúde e Sociedade. 2006;15:90-8.

7. Scopinho RA, Eid F, Vian CE, Silva PRC. New technologies and worker's health: mechanization of sugar cane harvesting. Cad Saude Publica. 1999;15(1):147-61.

8. Alves F. O processo de trabalho e danos á saúde dos cortadores de cana. INTERFACHS- Revista de gestão integrada em saúde do trabalho e meio ambiente. 2008;3(2):1-5.

9. Alessi NP, Navarro VL. Health and work in rural areas: sugar cane plantation workers in Riberão Preto, São Paulo, Brazil. Cad Saude Publica. 1997;13(Suppl 2):111-21.

10. Ferreira LL, Gonzaga MC, Donatelli CS, Bussacos MA. Análise coletiva do trabalho dos cortadores de cana da região de AraraquaraSP. FUNDACENTRO; 2008.

11. Jeacocke NA, LM B. Methods to standardize dietary intake before performance testing. Int J Sport Nutr Exerc Metab 2010;20(2):87-103.

12. Mäestu J, Eliakim A, Jürimäe J, Valter I, Jürimäe T. Anabolic and catabolic hormones and energy balance of the male bodybuilders during the preparation for the competition. J Strength Cond Res. 2010;24(4):1074-81.

13. Rocha FLR, Marzioli MHP, Robazzi MLCC. Proverty as a predisposing and ilness tendencies in sugar cane workers. Rev latino-americana de Enfermagem. 2007;15:736-41. 
14. Langowski E. Queima da cana: uma prática usada e abusada. 2007. Disponível em htpp://www.apromac.org.br. Acessado em 09.09.2009.

15. Silva MAM. Mortes e acidentes nas profundezas do "mar da cana e dos laranjais paulistas". INTERFACEHS- Revista de gestão integrada em saúde do trabalho e meio ambiente. 2008;3:1-31.

16. William R. Exertional heat stroke: life-saving recognition and onsite treatment in athletic settings. Rev Bras Med Esporte. 2005;11:363-6.

17. Casa JD, Clakson PM, Roberts WO. American College of Sports medicine rountable on hydratation and physical activity: Consensus Statements. 2005.

18. American Conference of Governamental Industrial Hygienist-ACGIH ${ }^{@}$. TLVs $^{@}$ and BEls ${ }^{@}$ - Threshold Limit values and Biological Exposure Indices. . 2010.

19. Barros Neto TL, César MC, Tebexreni AS. Fisiologia do Exercício. Capítulo 1. In: Fisologia do Exercício. Ed Manole, editor.; 2003.

20. Radak Z, Chung HY, Koltai E, Taylor AW, Goto S. Eercise, oxidative stress and hormesis. Ageing Research Reviws. 2008;7:34-42.

21. Guyton AC, Hall JE. Fisiologia do esporte. Capítulo 84, pgs. 10551066. In: Tratado de Fisiologia Médica Elsevier editora. $11^{\mathrm{a}}$ edição. 2006. .

22. Leung FP, Yung LM, Laher I, Yao X, Chen ZY, Huang Y. Exercise, vascular wall and cardiovascular diseases. Sports Med. 2008;38(12):1009-24.

23. Laufs U, Werner N, Link A, Endres M, Wassmann S, Jurgens K, Miche E, Bohm M, G N. Physical training increases endhotelial progenitor cells, inhibits neointima formation and enhances angiogenesis. Circulation. 2004;109:220-6.

24. Tinken TM, Thijssen DHJ, Hopkins N, Dawson EA, Cable NT, Green DJ. Shear stress mediates endothelial adaptations to exercise training in humans. Hypertension. 2010;55:312-8.

25. Mackinnon LT. Ovetraining effects on immunity and performance in athletes. Immunology and Cell Biology. 2000;78:502-9.

26. Souza-JR TP, Oliveira PR de, Pereira B. Exercício físico e estress oxidativo. Rev Bras Med Esporte. 2005;11(1):91-6.

27. Tanskanen $M$, Atalay $M$, Uusitalo $A$. Altered oxidative stress in overtrained athletes. J of Sports Sciences. 2010;28(3):309-17.

28. Margonis K, Fatouros IG, Jamurtas AZ, Nikolaidis MG, Dousouds I, Chatzinikolaou A, Mitrakou A, Mastorakos G, Papassotiriou I, Taxidaris K, Kouretas D. Oxidative stress biomarkers responses to physical overtraining: implications for diagnosis. Free Radic Biol Med. 2007;43(6):901-10. 
29. Meeuser R, Watson P, Hasegawa H, Roelands B, Placentini MF. Brain neurotransmitter in fatigue and overtraining. Appl Physiol Nutr Metab. 2007;32(5):857-64.

30. Rogero MM, Tirapegui J. Aspectos neuroendócrinos e nutricionais em atletas com overtraining. Arquivos Bras de End e Metab. 2005;49(43):359-68.

31. Purvis D, Gonsalves S, Deuter PA. Phybiological and psycological fatique in extreme conditions: overtraining and elite athelets. Physical Med and Rehabilitation. 2010;2(5):442-50.

32. Main LC, Dawson B, Heel K, Grave JR, Lardeis GJ, Goodman C. Relation between inflamatory cytokines and self-report measures of training overload. Res Sport Med. 2010;18(2):127-39.

33. Roose J, de Vries WR, Schmikli SL, Backx FJ, van Doornen LJ. Evaluation and opportunities in overtraining approaches. Res Q Exerc Sport 2009;80(4):756-64.

34. Rossi L, Tirapegui J. Aspectos atuais sobre exercício físico, fadiga e nutrição. Rev Paulista de Ed Física. 1999;13(1):67-82.

35. Tarini VAF, Vilas L, Zanuto R, Silva HCA, Oliveira ASB. Calor, exercício físico e hipertemia: epidemiologia, etiopatogenia, complicações, fatores de risco, intervenções e prevenção. Rev de neurociências. 2006;14(6):144-52.

36. Daher EF, Silva-Junior JG, Brunetta DM, Pontes LB, Bezerra GB. Rhabdomyolisis and acute renal failure after strenuous exercise and alchhol abuse: case report and literatures review. São Paulo Med J. 2005;123:33-7.

37. Rosa NG, Silva G, Teixeira A, Rodrigues F, Aarújo JA. Rabdomiolise. Acta Méd Port. 2005;18:271-82.

38. Phoolchund HN. Aspects of occupational health in the sugar cane industry. J Soc Occup Med. 1991;41(3):133-6.

39. Ndamba J, Makaza N, Kaondera KC, Munjoma M. Morbidity due to Schistosoma Mansoni among sugar-cane cutters in Zimbabwe. Int J epidemiol. 1991;20(3):787-95.

40. Ndamba J, Makaza N, Munjoma M, Gomo E, KC K. The physical fitness and work performance of agriculural workers infected with Schistosoma Mansoni in Zimbabwe. Ann Trop Med Parasitol. 1993;87(6):553-61.

41. Robbins TG, Salie FR, T G. Occupational hazards, living condition and physical assault of sugar cane workers in Kawazulu-Natal, South Africa. S Afrc Med J. 1998;88(9):1117-27. 
42. Crutzen PJ, Andreae MO. Biomass burning in the tropics: impact on atmospheric chemistry and biogeochemical cycles. Science. 1990;250 (4988):1669-78.

43. Cançado JED, Saldiva PH, Pereira LAA, Lara LBSS, Artago P, Martinelli A, Arbex MA, Zanobetti A, Braga ALF. The impact of sugar cane-burning emissions on the respiratory system of children and the elderly. Environ Health Perspect. 2006;114(5):725-9.

44. Kunzila N, Targer IB. Air pollution: from lung to heart. Swiss Med Wkly. 2005;135:697-702.

45. Pekkanen J, Peters A, Hoek G, Tittanen P, Brunekreef B, de Hartog J, Heinrich J, Ibald-Mulli A, Kreyling WG, Lanki T, Timonen KL, Vanninen E. Particulate air pollution and risk of ST-segment depression during repeated submaximal exercise test among subjects with coronary heart disease: The Exposure and Risk Assessment for fine and Ultrafine Particles in Ambient Air (ULTRA) Study. Circulation. 2002;106(8):933-8.

46. Poloniecki JD, Atkinson RW, Leon AP de, Anderson HR. Daly time series for cardiovascular hospital admissions and previus day's airpollution in London, UK. Occup Environ Med. 1997;54:535-40.

47. Vemylen J, Nemman A, Nemery B, Hoylaets MF. Ambient air pollution and acute myocardial infaction. J Thromb Haemost. 2005;3:1955-61.

48. Arbex MA, Martins LC, Oliveira RC de, Pereira LAA, Arbex FF, Cançado JED, Saldiva PH, Braga ALF. Air pollution from biomass burning and asthma hospital admissions in a sugar cane plantation area in Brazil. J Epidemiol Community Health. 2007;61 (5):395-400.

49. Brook RD, Rajagopalan S, Pope CA 3rd, Brook JR, Bhatnagar A, Diez-Roux AV, Holguin F, Hong Y, Luepker RV, Mittleman MA, Peters A, Siscovick D, Smith SC Jr, Whitsel L, Kaufman JD. Particulate matter and air pollution and cardiovascular disease: An update to the scientific statement from the American Heart Association. Circulation. 2010;121:2331-78.

50. Cançado JED, Braga ALF, Pereira LAA, Arbex MA, Saldiva PH, UP S. Clinical repercussions of exposure to atmospheric pollution. J Bras Pneumol. 2006;32(Suppl 2):s5-11.

51. Hoffmann B, Moebus S, Dragano N, Stang A, Mohlen-Kamp S, Schmermund A, Memmesheimer M, Brocker-Pneuss M, Mann K, Erbel $\mathrm{R}, \mathrm{K}$ J. Chronic residential exposure to particulate matter air pollution and systemic inflammatory markers. Environ Health Perspect. 2009;117(8):1302-8.

52. Santos UP, Braga ALF, Giorgi DM, Pereira LAA, Gruppi CJ, Lin CA, Bussacos MA, Zanetta DM, Saldiva PH, Terra-Filho M. Effects of air pollution on blood pressure and heart rate variability: a panel study of 
the vehicular traffic controllers in the city of São Paulo, Brazil. Eur Heart. 2005;26(2):193-200.

53. Jesus AA, E Nel A. Particulate matter and atheroaclerosis: role of particle size, composition and oxidative stress. Particle and Fibre Toxicology. 2009;6:1-19.

54. Macnee W, Donaldson K. Mechanisms of lung injury cased by PM10 and ultrafine particles with special reference to COPD Eur Resp J. 2003;Suppl 40:S47-S51.

55. Mossman BT, Born PJ, Gatranova V, Costa DL, Donaldson K, Kleeberg SR. Mechanisms of action of inhaled fibers, particles and nanoparticles in lung and cardiovascular diseases. Particle and Fiber Toxicolog, 4:4, artigo disponível em:wwwparticleandfibretoxicology $\backslash 4 \backslash \backslash 4.2007$.

56. Pope CA 3rd, Thun MJ, Namboodiri MM, Dockery DW, Evans JS, Speize R, Heath JRCW. Particulate air pollution as a predictor of mortality in aprospective study of US adults. Am J Respir Crit Care Med. 1995;151(3):669-74.

57. Dockery DW, Pope CA 3rd, Xu X, Spengler JD, Ware JH, Fay ME, Ferris BG, Speizer FE. An association between air pollution and mortality in six US cities. N Engl J Med. 1993;329(24):1753-9.

58. Sarnat JA, Marmur A, Klein M, Kim E, Russel AG. Fine particle sources and cardiorespiratory morbidity: an application of chemical mass balance and factor analytical source-aprortionment methods. Environ Health Perspect 2008;116(459-66).

59. Arbex MA, Bohm GM, Saldiva PH, Conceição GM, Pope CA 3rd, ALF B. Assessment of the effects of sugar cane burning on daily counts of inhalation therapy. J Air Wasre Manag Assoc. 2000;50(10):1745-9.

60. Arbex MA, Saldiva PH, Pereira LAA, Braga ALF. Impact of outdoor biomass air pollution on hypertension hospital admissions. J Epidemiolo Community Health .2010;64:573-9.

61. Lopes FS, Ribeiro H. Mapeamento de internações hospitalares por problemas respiratórios e possíveis associações á exposição humana aos produtos da queima da palha de cana-de-açúcar no estado de São Paulo. Rev Bras Epidemiologia. 2006;9(2):215-25.

62. Boopathy R, Asmabadi BR, Ferguson TG. Sugar cane (Saccharum Officinarum $L$ ) burning and asthma in Southeast Louisiania, USA. Bull Environ Cotam Toxicol. 2002;8(2):173-9.

63. Torres-Duque C, Maldonado D, Pérez-Padilla R, Ezzati M, Viegi G. Biomass fuels ans repiratory disease: a review of the evidence. Proc AM Thorac Soc. 2008;15(5):577-90. 
64. Amre DK, Infante-Rivard C, Dufresne A, Durgawale PM, Ernest P. Case-control study of lung cancer among sugar cane farmers in India. Occup Environ Med. 1999;56(8):548-52.

65. Bosso RMV, Amorin LMF, Andrade SJ, Rossini A, Marchi MMR de, Leon AP de, Camareto CMA, NDT C-F. Effects of genetic polymorphisms CYP1A1, GSTM1 and GSTP1 on urinary 1hidroxypyrene levels in sugar cane workers. Science of the Total Enviromental. 2006 (370):382-90.

66. Volpino $\mathrm{P}$, Tomei $\mathrm{F}$, La valle $\mathrm{C}$, Tomao $\mathrm{E}$, Rosati Mv, Ciarroca M, Cangemi B, Vigliarolo R, Fedele F. Respiratory and cardiovascular function at rest and during exercise testing in a health working population:effects of outdoor traffic air pollution. Occup Med (Lond). 2004;54(7):475-82.

67. Carlisle A, Sharp N. Exercise and outdoor ambient air pollution. Br J Sports Med. 2001;35(4):214-22.

68. Daigle CC, Chalupa DC, Gibb FR, Morrow PE, Obendorter G, Utell Mj, Frampton MW. Ultrafine particle deposition in humans during rest and exercise. Inahal toxicol. 2003;15(6):539-52.

69. Langrish P, Mills NI, chan JK, Li J, Laserman DL, Aiken RJ, Fokkens $\mathrm{PH}$, Casser FR, Newby DE, Donal;dson K, Jiane L. Beneficial cardiovascular effects of reducing exposure to particulate air pollution with a simple facemask. Particle and Fibre Toxicology. 2009;13:6-8.

70. Ministério da Previdência Social, INSS. Prevalência de doenças por categorias de ocupações. 2008. Disponível em : http/www.previdenciasocial.gov.br/dataprev. Acessado em: 20\12\2009.

71. Governo do Estado de São Paulo, Secretaria do Meio Ambiente, Secretaria da Agricultura e meio ambiente, União da Agroindústria Canavieira de São Paulo-Unica. Protocolo Agroambiental. 2007.

72. CIAGRO. Dados metereológicos. Disponível em: http/ www.ciagro.com.br. Acessado em 4\08\09.

73. Ministério do Trabalho e Emprego, MTE. Consolidação das Lei Trabalhistas. Normas regulamentadoras (NRs). Portaria 3214; 1984.

74. Sociedade Brasileira de Cardiologia, Sociedade Brasileira de Hipertensão, Socieddae Brasileira de Nefrologia, Décio Mion JrCoordenador. V Diretrizes Brasileira de Hipertensão Arterial. 2006. Pags:e24 - e78.

75. Flohé L, Günzler WA. Assays of glutathione peroxidase. Methods Enymol. 1984;105:114--21.

76. Calberg I, Mannervik B. Purification and characterization of the flavoenzyme glutathione reductase from rat liver. J Biol Chem. 1975;250:5475-80. 
77. Sim AS, Salonikas C, Naidoo D, Wilcken DE. Improved method for plasma malondialdehyde measurement by high-performance liquid chromatography using methyl malondialdehyde as an internal standard. J Chromatrogr B. 2003;785:337-44.

78. Sørensen M, Daneshvar B, Hansen M, Dragsted LO, Hertel O, Knudsen L, Loft S. Personal $\mathrm{PM}_{2,5}$ and markers of oxidative stress in blood. Environ Health Perspect. 2003;11(12):161-5.

79. ATS/ERS, Task Force. Standardization of lung fuction testing. General considerations for lung function. Eur Respir J. 2005;26:153-61.

80. ATS/ERS, Task Force. Standardization of lung function testing. Eur Respir J. 2005;26:319-38.

81. Pereira CA, Neder JA. Diretrizes para teste de função pulmonar. Jornal de Pneumologia. 2002;8(Supl):S1-82.

82. Neder JA, Abndreoni S, Lerario MC, Nery LE. Reference values for lung functions test II. Maximal respiratory and voluntary. Braz J Md Biol Resp. 1999;32(6):719-27.

83. Dubois $A B$, Botelho SY, Comroe JH. A new method for measuring airway resistence in man using a body plethsmograph: values in normal subjects and in patients with respiratory disease. J Clin Invest. 1956;35:327-35.

84. ATS, Statement. Guidelines for methacoline and exercise challenge testing. Am J Respir Crit Care Med. 2000;161:309-29.

85. ATS, Statement. Guidelines for six-minute walk test. Am J Respir Crit Care Med. 2000;166:111-7.

86. Borg GA. Psychophysical bases of perceived exertion. Med Sci Sports Exerc. 1982;14(5):377-81.

87. Soc Bras de Hipertensão, Soc Bras de Cardiologia, Soc Bras de Nefrologia. IV Diretrizes brasileiras para uso da monitorizaçào ambulatorial da pressão arterial (MAPA) e II Diretrizes para uso de monitorização residencial da pressão arterial. Arquivos Bras de Cardiologia. 2004;82(Supl IV):7-14.

88. Task Force of Eur Soc Cardiology, North Am Society, Eletrophysiology. Heart rate variability. Satandarts of measurement physiological interpretation and clinical use. Circulation. 1996;93:104365.

89. Singh SJ, Morgan MD, Scott S, Walters D, Hardman AE. Development of a shuttle walking test of disability in patients with cronic airways obstruction. Thorax. 1992;47:1019-24.

90. ATS, ACPP. Statement on cardiolopulmonary exercise testing. Am J Respir Crit Care Med. 2003;167:211-77. 
91. Soc Bras de Cardiologia. II Diretrizes da Sociedade Brasileira de Cardiologia sobre o teste ergométrico. 2002;2002.

92. Negrão CE, Rondon MUPB, Tinucci T, Alves MJN, Roneda F, Braga AMW RS, Mastari L, Barreto ACP, Krieger EM, HR M. Abnormal neurovascular control during exercise is linked to heart failure severity. Am Physiological Society. 2001;280(Suppl):H286-92.

93. Kavakama J, Silva CIS, Jasinowodolinski D, Terra-Filho M, Muller NL. Atlas e diagnóstico diferencial. Tomografia computadorizada de alta resolução do tórax. Revinter Ed, 1a ed.; 2008.

94. Landis RJHE, Koch GG. Avarage partial association in three-way contigency tables: a review and discussion of alternative test. International Satistic Review. 1978;46:237-54.

95. Trindade SHK, Mello-Junior JF de, Mion OG, Lorenzzi-Filho G, Macchione M, Guimaraes ET, Saldiva PH. Methods for studing mucociliary transport. Braz J of Otorhinolaryngology. 2007;73:704-12.

96. Tobert PE, Shy CM, Allen JW. Micronuclei and other nuclear abnormalities in buccal smears: methods and devolopment. Mutat Res. 1992;271:69-77.

97. Laat EF, Silva AJN, Luz VG. Impact over the working conditions:physical wear of sugar-cane cutters.2007. Disponivel em:http/plataformabndes.org.br. Acessado em ; 23\04\08.

98. Machado CM, Cardoso AA, Allen AG. Atmospheric emission of reactive nitrogen during biofuel ethanol production. Environ Sci Technol 2008;42(2):381-5.

99. World Health Organization, WHO. Air Guidelines for particulate matter, ozone, dioxid and sulfer dioxid. Global update 2005. Disponível em: http/www.Whol. Acessado em: 20.10.09.

100. Cesaroni G, Badaloni c, Porta D, Forastieri F, Perucci CA. Comparasion between varius indices of exposure to traffic-related air pollution and their impact on respiratory health in adults. Occup Environ Med. 2008;65:683-90.

101. Schelegle ES, Morales CA, Walby WF, Marion S, Allen RP. 6-6 hs hours inhalation of ozone concentrations from 60 to 87 parts per billion in health humans. Am j Heart Cir Physiol. 2009;180:265-72.

102. Tarlo SM. Cough:Occupational and environmental considerations. ACCP evidence-based clinical pratice guidelines. Chest. 2006 (Suppl):186-96.

103. Brancaccio $P$, Maffuli N, Limogelli FM. Creatinine kinase monitoring in sport medicine. British Medical Bulletin. 2007;81:287-30.

104. Brancaccio P, Maffulli N, Buonauro R, Limongelli FM. Serum enzyme monitoring in sports medicine. Clin Sports Med. 2008;27:1-18. 
105. Santos NSJ dos, Draibe AS, Kamimura MA, Cuppari I. Albumina sérica como marcador nutricional em pacientes em hemodiálise. Rev de nutrição. 2004;17(3):339-49.

106. Noakest T. Fluid replacement during marathon runing. Clin J Sport Med. 2004;14(4):248-50.

107. Garigan TP, Ristedt DE. Death from hyponatremia as result of acute water intoxication in a Amy Basic Trainee. Mil Med. 1999;164(13):2348.

108. Robisson RR. Doenças renais. Parte VI. Em: Cecil Tratado de Medicina Interna. 16a Edição. Editora Guanabara. 1990.

109. Chuang Kj, Chan CC, Suta C, Lee CT, Tang CS. The effect of urban air pollution on inflamation, oxidative stress, coagulation and autonomic dysfunction in young adults. Am J Respir Crit Care Med. 2004;176:370-6.

110. Baccarelli A, Zanobetti A, Martinelli I, Grillo P, Hou L, Giacomini S, Bonzini M, Lanzani G, Mannucci PM, Bertazzi PA, Schwartz J. Effects of exposure to air pollution on blood coagulation. $\mathrm{J}$ of Thrombosis and hemostasis. 2007;5 (2):252-60.

111. Sangani RG, Soukup JM, Ghio AJ. Metals in air pollution particles decrease whole-blood coagulation time. Inhal Toxicol. 2010;22(8):6216.

112. Mazzoli-Rocha F, Magalhães $\mathrm{CB}$, Malm O, Saldiva PH, Zin WA, Faffe DS. Comparative respiratory toxicity of particles produced by traffic and sugar cane burning. Environ Research. 2008;108(1):35-41.

113. Cerneca F, Crocetti G, Gombacci A, Simeone R, Tamaro G, Mangiarotti MA. Variations in hemostatic parameters after nearmaximum exercise and specific test in athletes. J Sports Med Phs Fitness. 1999;39(1):31-6.

114. Cerneca F, Simeone R, Bruno g, Gombacci A. A coagulation parameters in senior athletes praticing endurance sporting activity. J Sports Med Phs Fitness. 2005;45(4):576-9.

115. Peters $A$, Frobtich $M$, Doning $A$, Immervoll $T$, Wichmann HE, Hutchinson WL, Pepys MB, Koeing W. Particulate air pollution is associated with acute phase response in men:results from theMONICA-Augsburg Study. Eur Heart. 2001;22:1198-204.

116. Seaton A, Soutar A, Crawford V, Elton R, MCnerlan S, Cherrie J, Watt $\mathrm{M}$, Aglus R, Stout R. Particulate air pollution and the blood. Thorax. 1999;54:1027-32.

117. Forbes LJL, Patel MD, Rudnicka AR, Alicja R, Cook DJ, Bush T, Stedman JR, Whincup PH, Strachan DP, Anderson HR. Chronic exposure to out door air pollution and marker of systemic inflammation. Epidemiology. 2009;20(2):245-53. 
118. Brauner EV, Muller P, Barregar L, Dragsted LO, Glassius M, Whalin P, NVinzents $P$, Rasschoud-Nielsen $O$, Loft $S$. Exposure to ambient concentrations of particulate on pollution does not influence vascular of inflammatory pathways in young healths individuals. Fibre Toxicology. 2008;5:1-4.

119. Rudez G, Janssen NAH, Killinc E, Leebeek ME, Spronk HMH, Cate $\mathrm{HT}$, Casse FR, Maat MPM. Effects of ambient air pollution on homeostasis and inflammation. Environ Health Perspect. 2009;117:995-1001.

120. Kasapis C, Thompson PD. The effects of physical activity on serum Creative-protein and inflammatory markers. State of the art. $\mathrm{J}$ of The Am Col of Cardiology. 2005;45:1563-9.

121. Anderson J, Jansson JH, Hellsten G, Nilisson TK, Hallmans G, Boman $\mathrm{K}$. Effects of heavy endurance physical exercision inflammatory markers in non athlets. Atherosclerosis. 2009;10:1-5.

122. Lakka TA, Lakka HM, Rankinen T, Leon AS, Rao DC, Skinner JS, Wilmore $\mathrm{JH}$, Bouchard $\mathrm{C}$. Effect of exercise training on plasma levles of C-reative-protein in healthy adults: The HERITAGE Family Study. Eur Heart J. 2005;19:2018-25.

123. Aguilló A, Tauler P, Pilar-Guix M, Villa G, Córdova A, Tur JA, Pon A. Effect of exercise intensity and training on antioxidants and cholesterol profile in cyclist. J of Nutrition. 2003;14:319-25.

124. Ghorayeb N, Barros T. O exercício- Preparação fisiológica, avaliação médica, aspectos especiais e preventivos. Atheneu ed.; 1999.

125. Wilson DW, Aung HH, Lame MW, Plummer L, Pinkerton KE, Ham W, Kleeman M, Noris JW, Tablin F. Eposured of mice to concentrated ambient particulate matter results in platelet and systemic cytokine activation. Inahal Toic. 2010;22(4):267-76.

126. Reed MC, Campen Mj, Giogliotti AP, Harrod KS, MCDonald JD, Seagrave JC, Mauderly JL, Seilkop SK. Health effects of subchronic eposure to environmental levels of hardwood smoke. Inahal Toxic. 2006;18(8):523-39.

127. Uzma A, Salar BM, Kumar BS, Aziz N, David MA, Reddy VD. Impact of organic solvents and environmmental pollutants on the physiological function in petrol filling workers. Int $\mathrm{J}$ Res Public Health. 2008;5(3):139-46.

128. Holgate ST, Devlin RB, Wilson SJ, Frew AJ. Health effects of acute exposure to air pollution. Part II: Health effects of acute ambient particles. Res Rep Health Eff Inst. 2003;112:31-50.

129. Broadbent S. Seasonal changes in haematology, lymphocyte transferrin receptors and intracellular ironman triathletes and untrained men. Eur J Apll Physiol [epub ahead of print]. 2010. 
130. Kabasakalis A, Kyparos A, Tsalis G, Loupos D, Pavidou A, Kouretas D. Blood oxidative stress markers after ultramarathon swimming. [epub ahead for print]. J Strength Cond Res. 2010.

131. Ferreira F, Ferreira R, Duarte JA. Stress oxidativo e dano oxidativo muscular esquelético:influência do exercício físico agudo e inabitual e do treino físico. Rev Port Desp. 2005;5:257-79.

132. Braurer EV, Forchhammer L, Muller P, Simonsen J, Glasius M, Whalin $P$, Raaschow-Nielsen O, Loft $S$. Exposure to ultrafine particles from ambient air and oxidative stress-induced DNA damage. Environ Health Perspect. 2007;115:1177-82.

133. Vinzents PS, Muller P, Serensen M, Knudsen LE, Hertel O, Jansen FM, Schibye B, Loft S. Personal exposure to ultrafine particles and oxidative DNA damage. Environ Health Perspect. 2005;113:1485-90.

134. Marzatico F, Pansarasa O, Bertorelli L, Sonezini L. Blood free radical antioxidant enzymes and lipidic peroxides following long distance and lactacidemic performances on highly trained aerobic and sprint athletes. J Sports Med Phys Fitness. 1997;37(4):235-9.

135. Pinho RA, Silveira PCL, Piazza M, Tuon T, Silva GA, Dal-Pizzol F, Moreira JCF. Exercício físico regular diminui o estresse oxidativo em ratos após exposição aguda ao carvão mineral. Rev Bras de Med Esporte. 2006;12(2):81-4.

136. Pereira CA, Viegas CA, Alves RL. Capacidade de difusão do monóxido de carbono. Jornal de Pneumologia. 2002;28(Supl):S12238.

137. Stokes DL, Macintyre NR, Madel JA. Nonlinear increases in diffusing capacity during exercise by seated and supine subjects. J of Applied Physiology. 1981;51:858-63.

138. Schelegle ES, Walby WF, Adams WC. Time course of ozone-induced changes in breathing pattern in healthy exercising humans. $J$ of Applied Physiology. 2007;102:688-97.

139. Kjaergaard SK, Pederson DF, Miller MR, Rasmussen TR, Hansen JC, Malhave L. Ozone exposures decreases the effect of a deep inhalation on parced expiratory flow in normal subjects. J of Applied Physiology. 2004;96:1651-7.

140. Mendonça EMC, Silva RCC, Algranthi E. Função pulmonar e reatividade brônquica inespecífica em trabalhadores de terminal rodoviário Tietê-SP, expostos a produtos da exaustão dos motores diesel. Rev Saúde Ocupacional. 1991;19:20-4.

141. Rijcken B, Schouten JP, Men Sing TT, Weiss ST, Devries K, Van Der Lende $R$. Factors associated with bronchialresponsiveness to histamine in population sample of adults. Am Rev Resp Dis. 1993;147:1447-53. 
142. Leunberg $P$, Schindler $C$, Scwartz J, Ackema M, Liebrich U, Tara D, Perruchond AP, Wuffhrich B, Zell-Weger JP, Blaser K, Bolognini G, Bomgard JP, Brandi O, Domenighetti G, Elsasser S, Crize L, Karrer R, Keller R, Krunzli N, Medici T, Schoni NH, Solari T, Schopp JM, Villiger B, Zemp E. Occupational exposure to inhalative irritants and methacoline responsive. Scand J Work Environ Health. 2000;26:14652.

143. Bartolli CR, Wellwnius GA, Diaz EA, Lawrence J, Coull BA, Akiyama I, Lee LM, Okabe K, Verrier RL, Godleski JJ. Mechanism of inhaled fine particulate air pollution-induced arterial blood pressures changes. Environ Health Perspect. 2009;117:361-6.

144. Brook RA, Brook JR, Urch B, Vicent R, Rajagopalan S, Silverman F. Inhalation of fine particulate air pollution and ozone causes acute arterial vasoconstriction in healthy adults. Circulation. 2002;105:15346.

145. Guyton AC, Hall JE. O papel dominante dos rins na regulação a longo prazo da pressão arterial e da hipertensão. Capitulo 19. Em: Fisiologia Médica. RJ Elsevier, 11ª ed.; 2006.

146. Alpérovitch A, Lacombe JM, Hanon O, Dartigues JF, Ritchie K, Ducimetière $P$, Tzourio $C$. Relationship between blood pressure and outdoor temperature in a larger sample of eldery individuals: the three city study. Arch Intern Med. 2009;169(1):78-80.

147. Campos JR RR, Oliveira-Sales E, Bargamaschi CT. Regulação neurohumoral do sistema cardiovascular. Capítulo 1. In: Tratado de cardilogia. SOCESP. Manole Ed. 2009.

148. Irigoyen MC, Lacchini S, De Angelis K, Pereira AC, Krieger JE, Krieger EM. Fisiopatologia da hipertensão arterial. Capitulo 2. In : Tratado de cardilogia. SOCESP. Manole Ed. 2009.

149. Brook RD, Urch B, Dovonch JT, Bard RL, Speck M, Keeler G, Morishita M, Marsik FJ, Kamal AS, Kaciroti N, Harkema J, Corey P, Silverman F, Gold DR, Wellwenius G, Mitleman MA, Rajagopalan S, Brook JR. Insights into mechanisms and mediators of the effects of air pollution exposure on blood pressure and vascular function in healthy humans. Hypertension. 2009;54:659-67.

150. Romieu I, Castro-Giner F, Kunzli N, Sunyer J. Air pollution, oxidative stress and dietary supplementation: a review. Eur Respir J. 2008;31(1):179-97.

151. Yin Z, Yue P, Xu X, Zhong M, Sun Q, Mikolaj M, Wang A, Brook RD, Chen LC, $S$ R. Air pollution and cardiac remodeling: a role for RholRho-Kinase. Am J Physiol Heart Circ Physiol. 2009;296:H1540H50. 
152. Bankir L, Perucca J, MH W. Ethnic differences in urine concentration: possible relationship to blood pressure. Clin J Am Soc Nephrol. 2007;2(2):304-12.

153. Pope CA 3rd, Verrier RL, Lovet EG, Larson AC, Raizenne ME, Kanner RE, Schwartz J, Villegas GM, Gold DR, Dockery DW. Heart variability associated with particulate air pollution. Am Heart J. 1999;138:804-7.

154. Magari SR, Hauss R, Schwartz J, Williaans PL, Smith TJ, Christiani DC. Association of heart rate variability with occupational and environmental exposure to particulate air polluttion. Circulation. 2001;104:986-91.

155. Rumenig E, Bertuzzi RCM, Nakamura FY, Franchini E, Matsushingue KA, MAP Dm. Cinética da variabilidade da frequência cardíaca mediante exercício físico predominantemente aeróbico: influência da intensidade e do tempo de análise. Rev Bras de Educ Fis Esp. 2007;21:205-18.

156. Brum PC, Forjaz CLM, Tinucci T, Negrão CE. Adaptações agudas e crônicas do exercício físico no sistema cardiovascular. Rev Paulista de Ed Física. 2004;18:21-31.

157. Mucci P, Blondel N, Fabre C, Nourry C, Berthoin S. Evidence of exercise-induced $\mathrm{O}_{2}$ arterial desaturation in non-elite sportwomen followin high intensity interval-training. Int J Sports Med. 2004;24:71-6.

158. Tucotte P, Kiteala L, Marcotte JE, Perrault H. Exercise-induced oxyhemoglobin desaturation and pulmonary diffusion capacity during high-intensity exercise. Eur J Apll Physiol Occup Physiol. 1997;75(5):425-30.

159. Lama IL, Wolski LA, Couts KD, Mckenzie DC. The relations between test protocol and the devolopment of exercise-induced hypoxemia (EIH) in highly trained athletes. Eur J Apll Physiol Occup Physiol. 1996;74(4):330-5.

160. Miyai N, Arita M, Miyashita K, Morioka I, Shiraishi T, Noshio I. Blood pressure response to heart rate during exercise test and risk of future hypertension. Hypertension. 2002;39:761-7.

161. Singh JP, Larson MG, Manolio TA, O'Donnell J, Lauer M, EvansJC, Levy $\mathrm{D}$. Blood pressure response during treadmill testing as a risk factor for new-onset hypertension - The Framinghan Heart Study. Circulation. 1999;99:1831-6.

162. Neder JA, Nery LE. Teste do exercício cardiopulmonar. Jornal de Pneumologia. 2002;28(Supl 3).

163. Barros Neto,TL Tebexreni AS, Tambeiro VL. Aplicações práticas da ergoespirometria do atleta. 2001; 11(3): 695-705. 
164. Yazbek Jr P, Carvalho RT de, Sabbag LMS, Battistella LP. Ergoespirometria. Teste de esforço cardiopulmonar. Metodologia e interpretação. Arquivos Bras de cardiologia. 1998;71(5):719-24.

165. Spurr GB, Maksud MG, Barac-Nieto M. Energy expenditure, productivity and physical work capacity of sugarcane loaders. The Am $\mathrm{J}$ of Clinical Nutrition. 1977;30(10):1740-6.

166. Arjomandi M, Haight $\mathrm{T}$, Redberg R, Gold WM. Pulmonary function abnormalities in never smoking flight attendants exposed to secondhand tabaccosmoke in aircraft cabin. J Occup Environ Med. 2004;17:70-6.

167. Miils NL, Tornquist H, Robinson SD, Gonzalez M, Darnley K, Macnee W, Boon NA, Donaldson K, Blomberg A, Sandstrom T, Newby DE. Diesel exhaustion inhalation causes vascular dysfunction and impaired endogenous fibrinolysis. Circulation. 2005;112:3930-6.

168. Sun $Q$, Wang $A$, Jin $X$, Natanzon $N$, Duqualine $D$, Brook RD, Aguinaldo JD, Kayard ZA, Fuster V, Lippmann M, Chen LC, Rajagopalan S. Long-term air pollution exposure and acceleration of atherosclerosis andvascular inflammation in an animal model. JAMA. 2005;294:3003-10.

169. Hautala AJ, Kiviniemi AM, Makikallio TH, Tinanen S, Seppanen T, Huikuri HV, Tulppo MP. Muscle sympatic nerve activity at rest compared to exercise tolerance. Eur $\mathrm{J}$ Applied of Physiology. 2008;102(5):533-8.

170. Kara M, Bulut S, Tas F, Akkurt I, Seyfiki Z. Evaluation of pulmonary changes due to biomass fuels using high-resolution computed tomography. Eur Radiol. 2003;10:2372-7.

171. Nakagawa NK, Franchini ML, Driusso P, Oliveira LR de, Saldiva PH, Lorenzzi-Filho G. Muccociliary clearance is impaired in acutely ill patients. Chest. 2005;128:2772-7.

172. Belda J, Parameswaran K, Keiyh PK, Hareneave FE. Repeatability and validity of cell and fluid-phase measurements in nasal fluid: a comparasion of two methods of nasal lavage. Clin Expert Allerg 2001;31:1111-5.

173. Naclerio RM, Meler HL, Kagey-Sobotka A, Adkinson NF, Meyers DA, Norman PS, Linchterstein LM. A mediator release after nasal airway challenge with allergen. Am Rev Resp Dis. 1983;28:597-602.

174. Stanley PS, Wilson R, Grenstone MA, MacWillian L de, Cole PJ. Effect of cigarrete smoking on nasal mucicilary and ciliary beat frequency. Thorax. 1986;41(Supl):S19-23.

175. Ceppi M, Biasoti B, Fenech M, Bonassi S. Human population with the exfoliated buccal micronucleus assay: statistical and epidemiological issues. Mutat Res. 2009;20:1-9. 
176. Soares SRC, Bueno-Guimaraes HM, Ferreira CM, Rivero DHRF, De Castro I, Garcia MLB, Saldiva PH. Urban air pollution induces micronuclei in peripheral erytrocytes of mice in vivo Environ Research. 2003;2:191-6.

177. Chen C, Arjomandi M, Qin H, Balmes J, Targer IB, N H. Cynetic damage in buccal epithelia and peripheral lymphocytes of young health individuals exposed to ozone mutagenesis. Oxford $\mathrm{J}$ Mutagenics. 2006;21(2):131-7.

178. Celik A, Cavas T, Ergene-Gozukara S. Cytogenetic biomonitoring in petrol station attendants:micronucleis test in exfoliated buccal cels. Oxford J Mutagenics. 2003;18(5):417-21. 